University of Florida Levin College of Law

UF Law Scholarship Repository

Winter 2009

\title{
Enhanced Water Quality Protection in Florida: An Analysis of the Regulatory and Practical Significance of an Outstanding Florida Water Designation
}

\author{
Thomas T. Ankersen \\ University of Florida Levin College of Law, ankersen@law.ufl.edu \\ Richard Hamann \\ University of Florida Levin College of Law, hamann@law.ufl.edu \\ Rachel King \\ Megan Wegerif \\ John November
}

Follow this and additional works at: https://scholarship.law.ufl.edu/facultypub

Part of the Environmental Law Commons, and the Water Law Commons

\section{Recommended Citation}

Thomas Ankersen, Richard Hamann, Rachel King, Megan Wegerif \& John November, Enhanced Water Quality Protection in Florida: An Analysis of the Regulatory and Practical Significance of an Outstanding Florida Water Designation, 2 Sea Grant L. \& Pol'y J. 74 (2009), Available at http://scholarship.law.ufl.edu/ facultypub/674 
Enhanced Water Quality Protection in Florida: An Analysis of the Regulatory and Practical Significance of an Outstanding Florida Water Designation

\section{Thomas Ankersen, Richard Hamann, Rachel King, Megan Wegerif, John November ${ }^{1}$}

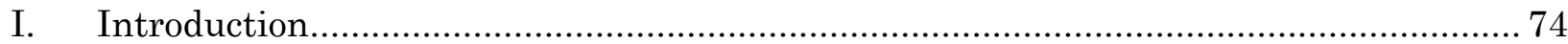

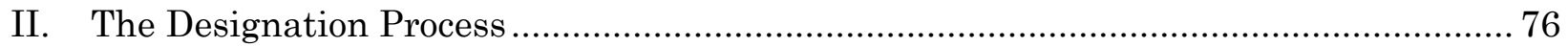

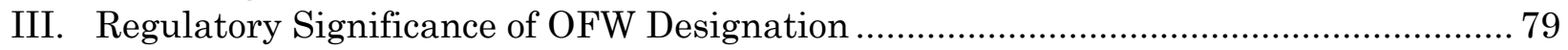

A. Environmental Resource Permits ........................................................................ 80

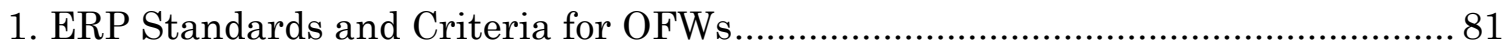

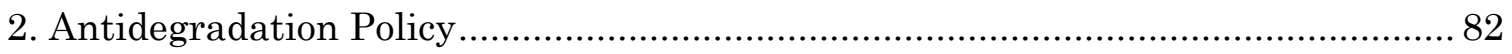

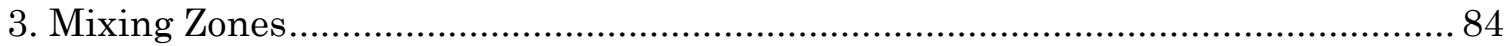

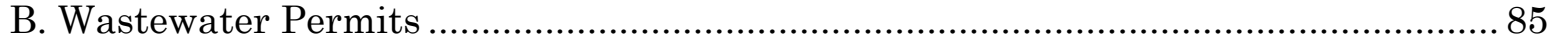

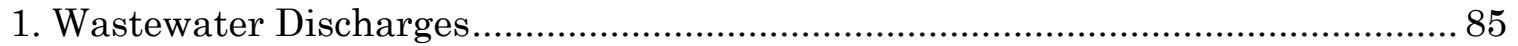

2. General and Generic Permits in OFWs............................................................. 86

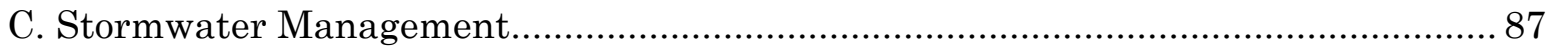

D. Docks, Piers, Docking Facilities and Marinas ................................................ 88

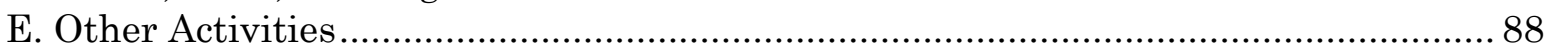

F. Best Management Practices for Silviculture Operations .................................... 89

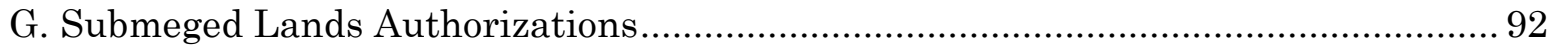

IV. Florida Case Law Addressing OFWs ..................................................................... 93

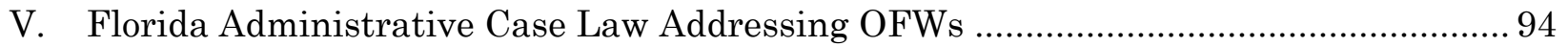

A. Reasonable Assurance and the Clearly in the Public Interest Test ...................... 95

B. The Role of Mitigation ................................................................................ 96

C. Nature of the Activity ..................................................................................... 96

D. "Significantly Degrades" and Geographic Proximity .......................................... 97

VI. Impact of OFW Designation on Transboundary Waters........................................... 99

VI. Key Issues in OFW Regulation and Enforcement ................................................ 100

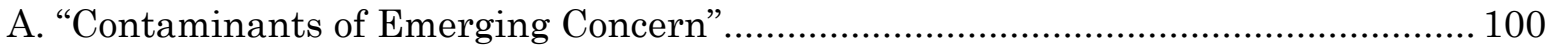

B. Riparian Buffers - Are BMPs enough Protection for OFWs? ............................. 102

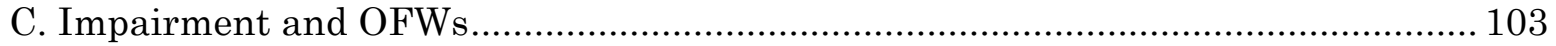

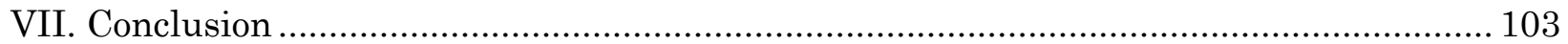

\section{Introduction}

The Outstanding Florida Water (OFW) designation is the highest protection offered to a body of water by the state of Florida and is available only to those waters whose "natural attributes" warrant it. An OFW designation provides that water body with an antidegradation standard for certain activities affecting its water quality. Ordinarily,

\footnotetext{
1 Thomas T. Ankersen, Legal Skills Professor and Director, Conservation Clinic, University of Florida College of Law; Richard Hamann, Associate in Law, Center for Governmental Responsibility, University of Florida Levin College of Law; Rachel King, J.D., 2009 Conservation Clinic Law Fellow; Megan Wegerif, J.D. \& LLM Candidate, University of Florida, Levin College of Law; and John November, J.D, University of Florida, Levin College of Law. The authors would like to acknowledge the St. Marys River Management Committee, whose initial interest in OFW designation for their watershed led to the this research by faculty and students affiliated with the University of Florida Conservation Clinic.
} 
waters in Florida must meet the criteria established by rule for their respective class of water (based on the Florida water body classification system), regardless of existing water quality. Once a water body is designated as an OFW, however, a baseline water quality standard is set based on the ambient water quality of that particular water body. Because the OFW water quality standard may be higher than the rule-based water quality classification criteria, regulated activities that may affect the OFW are subject to additional scrutiny by regulatory agencies. In addition, those activities not necessarily occurring within an OFW, but that may "significantly degrade" an OFW, are subject to heightened scrutiny.

The Florida OFW program is administered by the Florida Department of Environmental Protection (FDEP). Currently, more than 350 waters are designated as OFWs. These are divided into two categories, managed and special waters. Managed OFWs, referred to by FDEP as managed areas, are waters that lie within or adjacent to managed areas such as state parks and aquatic preserves. Special OFWs, or special waters, lie outside of managed areas and are adjacent to non-public lands. Special water designations have proved to be controversial and to date only $41 \mathrm{OFW}$ s have been designated in this manner.

The various activities that are generally subject to OFW standards include those needing Environmental Resource Permits (ERPs), stormwater and wastewater discharge permits, and dock permits. When activities subject to these approvals are proposed in an OFW, the applicant must demonstrate that the activity is "clearly in the public interest," as opposed to the more lenient test of "not contrary to the public interest" that is applicable to all other waters. For activities conducted outside OFWs that may affect OFWs, an applicant must demonstrate that the activity will not "significantly degrade" the OFW. For certain activities, the requirements are more explicit, such as reduced square footage for exempt docks in OFWs and a limitation on the amount of storage in stormwater basins. Buffers and other aspects of best management practices for silviculture are also subject to stricter criteria in OFWs.

The ability of current OFW regulation to fulfill the legislative intent behind the OFW designation remains uncertain. Judicial and administrative case law addressing OFWs provide little clear guidance in interpreting the statutory standards for the issuance of permits in or affecting OFWs, especially the "clearly in the public interest" standard. The effect of the designation on water quality parameters subject to a narrative standard (nutrients), and on water quality parameters that are not currently established by rule (e.g. emerging pathogens of concern) has not been established. The transboundary nature of some OFWs may implicate water quality standard setting in adjacent states, as a matter of federal law. The extent to which Best Management Practices (BMPs) for silviculture operations are sufficient to safeguard OFW water quality may require further research. In addition, the extent to which the OFW statute and rules recognize the ecological role of riparian zones remains in question.

\section{The Designation Process}


States are authorized by the federal Clean Water Act to adopt their own water quality standards ${ }^{2}$ and federal Environmental Protection Agency regulations direct the states to adopt antidegradation policies to prevent violations of those water quality standards. ${ }^{3}$ Pursuant to this grant of power, the Florida Legislature enacted the OFW designation in 1982. ${ }^{4}$ Section 403.061(27) of the Florida Statutes grants FDEP the power to: "Establish rules which provide for a special category of water bodies within the state, to be referred to as 'Outstanding Florida Waters', which shall be worthy of special protection because of their natural attributes." ${ }^{5}$ Moreover, the FDEP may establish stricter rules concerning OFW permits and enforcement. ${ }^{6}$ The Florida Environmental Regulation Commission (ERC), a seven-member citizens body appointed by the Governor, has final decision-making authority over the state water quality standards and other environmental standards proposed by the FDEP. ${ }^{7}$ Once a water body is designated as an OFW, the antidegradation policy operates to protect the OFW's ambient water quality from being lowered as a result of proposed activities or discharges, with some exceptions. ${ }^{8}$ However, only the area of the water that is within the legal boundary of the OFW is given this protection. ${ }^{9}$

There are two types of OFWs: "Managed Areas" and "Special Waters". Most managed area OFWs are within areas that are managed by either the state or federal government. ${ }^{10}$ These areas include wildlife refuges, parks, marine sanctuaries, some of the waters within the boundaries of state or national forests, and aquatic preserves. ${ }^{11}$ Managed Areas become OFWs through regular rulemaking that involves public notice, a public hearing, and an ERC Hearing. ${ }^{12}$ Some Managed Areas OFWs were designated by inclusion in the original legislation. ${ }^{13}$ In many circumstances, the waters within these public areas gained this special level of protection because the particular managing agency requested the OFW designation. ${ }^{14}$ Since Managed Areas OFWs are part of a larger preserved area, either state or federal, the legal boundaries of the OFW are subsumed within those of the park, preserve, protected area, etc. ${ }^{15}$ In most cases, all of the waters within that area are classified as OFW, unless specific areas are exempted by its listing rule. ${ }^{16}$ The FDEP is currently planning to update the list of Managed Areas OFWs for the first time in over ten

233 U.S.C. $\$ 1313(2008)$.

${ }^{3} 40$ C.F.R. $\S 131.12$ (2008).

${ }^{4} 1982$ FLA. LAWS volume I part I, s. 1, ch. 82-79, s. 2, ch. 82-80.

${ }^{5}$ FLA. STAT. §403.061(27) (2008).

${ }^{6}$ Id. $\$ 403.061(34)$.

${ }^{7}$ Id. $\S 403.804$.

8 Fla. AdMin. Code r. 62-4.242(2) (2008).

${ }^{9}$ Id. r. $62-302.700$.

10 Personal Communication, Janet Klemm, Outstanding Florida Waters Program, Florida Department of Environmental Protection. See also, FlA. Admin. CodE r. 62-302.700(9)(a)-(h) (2008).

${ }^{11} I d$.

${ }^{12}$ Id. r. 62-302.700(4).

${ }^{13}$ Id. r. 62-302.700(8).

${ }^{14}$ Personal Communication, Janet Klemm, supra note 10.

${ }^{15}$ Id. See also, Fla. Admin. Code, r. 62-302.700(9)(a)-(h) (2008).

${ }_{16}$ Personal Communication, Janet Klemm, supra note 10. 
years. ${ }^{17}$ FDEP has requested comments and suggestions from other state and federal management agencies regarding the update of the rule. ${ }^{18}$

"Special Waters" are designated through the same rulemaking process as Managed Areas OFWs. ${ }^{19}$ This process includes the submission of a petition by any person, public workshops, a staff investigation and report, and an ERC public hearing. ${ }^{20}$ Specifically regarding Special Waters OFWs, however, the ERC must find that the waters have "exceptional recreational or ecological significance" and that the "environmental, social, and economic benefits of the designation outweigh the environmental, social, and economic costs." 21 The petitions submitted to FDEP contain the legal boundary description of the specific area of water that the petitioner wishes to have designated as an OFW. ${ }^{22}$ Unless these boundaries are changed through the petition process, this description serves as the legal boundary for these Special Waters OFWs. ${ }^{23}$ Some descriptions are also found within the actual rule itself, as seen with the Florida Keys Special Water listing, in which the OFW boundary extends to Florida's territorial limit. ${ }^{24}$

There are currently over 350 OFWs, most of which are Managed Areas OFWs. ${ }^{25}$ The fortyone Special Waters OFWs include all or portions of Florida's 1700 rivers, several lakes and lake chains, several estuarine areas, and the Florida Keys. ${ }^{26}$ (See Table 1). Designation of Special Waters OFWs by petition has proved to be controversial in many cases. No data exists on the number of Special Waters petitions that have failed to reached regulatory fruition. The Weekiwachee Riverine and Spring System was the last Special Water designation, which occurred in $2003 .{ }^{27}$

Table 1: The 41 Special Waters OFW ${ }^{28}$

\begin{tabular}{|c|c|}
\hline Apalachicola River & Myakka River (lower part) \\
\hline Aucilla River & Ochlocknee River \\
\hline Blackwater River & Oklawaha River \\
\hline Butler Chain of Lakes & Perdido River \\
\hline Chassahowitzka River System & Rainbow River \\
\hline Chipola River & St. Marks River \\
\hline Choctawhatchee River & \\
\hline
\end{tabular}

17 Id

$18 \mathrm{Id}$.

19 Fla. Admin. Code, r. 62-302.700(4) (2008).

${ }^{20}$ Id. r. 62-302.700(4)-(5).

21 Id. r. $62-302.700(5)$.

$22 I d$.

$23 \mathrm{Id}$.

$24 I$.

25 Id. r. 62-302.700(9)(a)-(h) (2008).

26 Florida Department of Protection, Fact Sheet about Outstanding Florida Waters, http://www.dep.state.fl.us/WATER/wqssp/ofwfs.htm\#designation (last visited Feb. 15, 2010).

27 FlA. Admin. CODE, r. 62-302.700(9)(i)(38) (2008).

28 Table copied from FDEP, supra note 26. The actual rule language designating these water bodies is more complete. For further information, refer to Fla. Admin. Code r. 62-302.700(9)(i). 


\begin{tabular}{|c|c|}
\hline Clermont Chain of Lakes & Santa Fe River System \\
\hline Crooked Lake & Sarasota Bay Estuarine System \\
\hline Crystal River & Shoal River \\
\hline Econlockhatchee River System & Silver River \\
\hline Estero Bay Tributaries & Spruce Creek \\
\hline Florida Keys & Suwanee River \\
\hline Hillsborough River & Tomoka River \\
\hline Homosassa River System & Wacissa River \\
\hline Kingsley Lake \& Black Creek (North Fork) & Wakulla River \\
\hline Lake Disston & Weekiwachee Riverine System \\
\hline Lake Powell & Wekiva River \\
\hline Lemon Bay Estuarine System & Wiggins Pass Estuarine System \\
\hline Little Manatee River & Withlacoochee Riverine and Lake System \\
\hline Lochloosa Lake & \\
\hline
\end{tabular}

To begin the OFW rulemaking process, an interested party must submit a petition to FDEP requesting the water be listed in r. 62-302.700(9), Florida Administrative Code..$^{29}$ Aside from the practical requirement for a boundary description, there are few guidelines or specific requirements as to what must be included in a petition. Petitions must, however, include information and facts to support a finding of "ecological significance" or "recreational significance" as defined by $\S 120.54(7)$, Florida Statutes. Moreover, because there are requirements for the FDEP to follow during the rulemaking process (such as an economic analysis and public workshop), it is in the best interest of the petition to include information that will be useful to FDEP in accomplishing these tasks.

The submission of the petition triggers the OFW rulemaking requirements listed in r. 62302.700, Florida Administrative Code. ${ }^{30}$ If FDEP chooses to go forward with the rulemaking, it must conduct at least one fact-finding workshop in the geographic area that would be most affected by the OFW designation. ${ }^{31}$ Prior to this workshop, the FDEP Secretary must notify the local governments and legislators whose jurisdictions include the water body at issue in writing a minimum of 60 days prior to the workshop. ${ }^{32}$ In addition, a prominent public notice must be placed in a general circulation newspaper of the affected area at least 60 days prior to the workshop. ${ }^{33}$ The FDEP is required to keep a rulemaking record. ${ }^{34}$ The record should include the initial petition for rulemaking, an economic impact analysis, and the material covered at the public fact-finding workshop conducted by FDEP.

The FDEP is required to complete an economic impact analysis regarding the likely effects of the OFW designation on growth and development in the surrounding area. ${ }^{35}$ The economic impact analysis is drafted based on data gathered at the public workshops, by the

${ }^{29}$ FLA. STAT. §120.54(7) (2008).

30 FLA. AdMIN. CODE r. 62-302.700(4) (2008). As an overall requirement, the rulemaking procedures listed in Chapter 120, Florida Statutes, must also be followed throughout the process.

${ }^{31} I d$.

$32 I d$.

${ }^{33} I d$.

34 FLA. STAT. $\$ 120.54(8)$ (2008).

${ }^{35} I d$. 
FDEP's professional staff, and from the petitioner. The FDEP takes a multi-faceted approach when preparing an economic impact assessment. In addition to traditional economic indicators, the FDEP examines ecological values and a variety of sectors within the local economy including recreation and small businesses. The goal of the analysis is to provide the ERC with enough information to weigh the economic costs and benefits of the proposed designation.

The Department's economic impact analysis for the Sarasota Bay and Lemon Bay OFW designations illustrates this multi-faceted approach. ${ }^{36}$ While at the time of designation, Sarasota Bay had a high economic value because of recreational fishing ${ }^{37}$ and other recreational activities, ${ }^{38}$ Lemon Bay had a higher ecological value. ${ }^{39}$ In both cases, the Department concluded that the additional protection that an OFW designation would offer to these areas would safeguard their value, which offset the potential costs of compliance to local business and/or industry. ${ }^{40}$ The Department did note, however, that the water quality of Sarasota Bay and Lemon Bay prior to designation was relatively high, and that they were unaware of any dischargers who would be adversely affected. ${ }^{41}$

Upon the completion of the workshop and the economic impact statement, the decision as to OFW designation is directed to the Environmental Regulation Commission, as discussed above. ${ }^{42}$ To designate a water body as an OFW, the ERC must make two determinations at a public hearing after reviewing the relevant facts from the record. ${ }^{43}$ First, the ERC must determine that the water body has exceptional recreational or ecological significance. ${ }^{44}$ Second, the ERC must determine that the environmental, social, and economic benefits of the designation outweigh the environmental, social, and economic costs. ${ }^{45}$ Once the ERC makes an affirmative determination as to both of these requirements, the petition for rulemaking is approved and the water body becomes listed under r. 62-302.700(9), Florida Administrative Code.

\section{Regulatory Significance of OFW Designation}

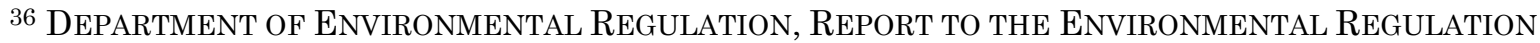
Commission, Proposed Designation of SARAsota Bay and Lemon Bay as OUtstanding Florida WATERS, Appendix L: Economic Impact Statement (1986).

${ }^{37} \mathrm{Id}$. The total annual economic value of recreational fishing in the Sarasota Bay area was estimated at $\$ 38,001,471$ in 1983 , at the time of the OFW designation.

${ }^{38} \mathrm{Id}$. The total annual economic value of all other recreational activities in the Sarasota Bay was estimated to be $\$ 9,949,223$ (in 1983 dollars).

${ }^{39} I d$.

${ }^{40} I d$.

${ }^{41} \mathrm{Id}$. Regulated industries that participate in the rulemaking process often provide detailed testimonial evidence on the economic impact of OFW designation from their perspective, which the Department must take into account. This can lead to negotiated solutions where shoreline segments are removed from OFW consideration.

42 FLA. AdMIN. CODE, r. 62-302.700(5) (2008).

${ }^{43} \mathrm{Id}$.

${ }^{44} I d$.

${ }^{45} I d$.
} 
The key regulatory feature of an OFW designation is its "antidegradation" standard. This stricter standard increases agency scrutiny of permits for activities within OFWs and increases the burden on applicants to demonstrate compliance. However, not all regulated activities are subject to OFW review and agency application of the standard of review for OFWs, especially the so-called "clearly in the public interest" test required for certain permitted activities, has been problematic. Moreover, the role of mitigation in meeting this standard for OFWs has not been adequately distinguished from non-OFW water bodies.

\section{A. Environmental Resource Permits}

The Environmental Resource Permit (ERP) Program was established in 1994 to regulate activities involving the alteration of surface water flows. ${ }^{46}$ Section 373.103(1), Florida Statutes, authorizes FDEP to administer and enforce the permitting systems established in the Water Resources Chapter of the Florida Statutes. According to FDEP:

[The ERP Program] regulates the construction, alteration, maintenance, removal, modification, and operation of all activities in uplands, wetlands and other surface waters (whether publicly or privately-owned) that will alter, divert, impede, or otherwise change the flow of surface waters. That includes dredging and filling in most surface waters and wetlands (whether isolated or connected to other waters). Example activities that the program covers are the construction of new buildings, roadways, and parking areas that increase impervious surfaces and stormwater runoff. The program is designed to ensure that such activities do not degrade water quality (from the discharge of untreated stormwater runoff) or cause flooding (from a change in off-site runoff characteristics). In addition, the ERP program regulates the type of dredging and filling activities reviewed under the former wetland resource (dredge and fill) permitting program, such as the dredging of navigation channels, filling of wetlands, and the construction of docks and seawalls. This ensures that water quality is not degraded, and that wetlands and other surface waters continue to provide a productive habitat for fish and wildlife. ${ }^{47}$

ERP applications are processed by either FDEP or one of the five state water management districts (WMD), in accordance with the division of responsibilities specified in the operating agreements between these entities. ${ }^{48}$ Within most WMDs, the FDEP is responsible for reviewing permit applications for the following activities:

- Solid waste, hazardous waste, domestic waste, and industrial waste facilities;

- Mining (except borrow pits that do not involve on-site material grading or sorting);

- Power plants, transmission and communication cables and lines, and natural gas and petroleum exploration, production, and distribution lines and facilities;

\footnotetext{
461994 FLA. LAWS volume I part II, s. 4, ch. 94-122.

47 Fact Sheet, Florida Department of Environmental Protection, Environmental Resource Permit Program Fact Sheet: Purpose and History (updated Oct. 1, 2007), available at http://www.dep.state.fl.us/water/wetlands/docs/erp/ERP_Fact_Sheet.pdf. Statutory authority for ERPs is found in Fla. Stat. §373.4144 (2008).

${ }^{48}$ Id. See also, FLA. STAT. §373.4141 (2008).
} 
- Docking facilities and attendant structures and dredging that are not part of a larger plan of residential or commercial development;

- Navigational dredging conducted by governmental entities, except when part of a larger project that a WMD has the responsibility to permit;

- Systems serving only one single-family dwelling unit or residential unit not part of a larger common plan of development;

- Systems located in whole or in part seaward of the coastal construction control line;

- Seaports; and

- Smaller, separate water-related activities not part of a larger plan of development (such as boat ramps, mooring buoys, and artificial reefs). ${ }^{49}$

All other proposed activities are reviewed by the WMDs in which the activity would be located. ${ }^{50}$

The ERP program is in effect throughout the state except for the Florida panhandle, which is within the limits of the Northwest Florida Water Management District (NWFWMD). In the NWFWMD, the Wetland Resource Permitting (WRP) Program, which regulates dredged and fill activities only, is still in effect. ${ }^{51}$ However, NWFWMD ERP rulemaking was authorized through amendments to $\S 373.4145$, Florida Statutes, in the 2006 legislative session to develop rules addressing stormwater quality and quantity. Rules for the NWFWMD ERP stormwater program became effective October 1, 2007.52 The remaining components of the comprehensive ERP program, referred to as "Phase 2," manages surface waters including isolated wetlands. ${ }^{53}$ These components have been proposed by FDEP for the NWFWMD and are currently awaiting approval. ${ }^{54}$

\section{ERP Standards and Criteria for OFWs}

The regulation of ERP activities is addressed by the Florida Statutes and the Florida Administrative Code. Chapter 373 Part IV, Florida Statutes, addresses the "Management and Storage of Surface Waters." Upon review of a standard ERP permit application, seven criteria listed in $\S 373.414(1)(a)$, Florida Statutes, must be analyzed, and the proposed activity must be found to be "not contrary to the public interest" in order for a permit to be issued. However, if the regulated activity is proposed within an OFW or will significantly degrade an OFW, the applicant has to meet a heightened standard by providing a "reasonable assurance that the proposed activity will be clearly in the public interest." 55

\footnotetext{
${ }^{49}$ Florida Department of Environmental Protection, Environmental Resource Permitting (ERP) and Sovereign Submerged Lands (SSL) Rules: Florida's Water Management Districts, http://www.dep.state.fl.us/water/wetlands/erp/wmd.htm (last visited February 26, 2010).

${ }^{50} I d$.

${ }^{51}$ FLA. STAT. $\S 373.4145$ and 403.811 (2008).

52 See, Fla. Admin. Code, ch. 62-346 (2008).

${ }^{53} \mathrm{Id}$.

${ }^{54} I d$. Copies of the current draft rule and amendments are available at http://www.dep.state.fl.us/water/wetlands/erp/rules/draft_nw.htm .

55 FLA. STAT. § 373.414(1) (2008).
} 
The Florida Legislature requires the DEP to consider a number of additional factors under both the OFW and non-OFW public interest test. The seven additional factors are:

- Whether the activity will adversely affect the public health, safety, or welfare or the property of others;

- Whether the activity will adversely affect the conservation of fish and wildlife, including endangered or threatened species, or their habitats;

- Whether the activity will adversely affect navigation or the flow of water or cause harmful erosion or shoaling;

- Whether the activity will adversely affect the fishing or recreational values or marine productivity in the vicinity of the activity;

- Whether the activity will be of a temporary or permanent nature;

- Whether the activity will adversely affect or will enhance significant historical and archaeological resources under the provisions of $\S 267.061$; and

- The current condition and relative value of functions being performed by areas affected by the proposed activity. ${ }^{56}$

However, the statute does not offer further guidance in the application of these factors as between the two tests. It appears that regardless of which test is applied, the weight be accorded each of these factors remains a question of law for the agency or court to decide. ${ }^{57}$

As a general note, a "de minimus" exemption is available for all activities governed by chapter 62 of the Florida Administrative Code. Structural activities that will not change "the quality, nature or quantity of air and water contaminant emissions or discharges or which will not cause pollution" are allowed without a permit. Additionally, r. 62-4.040, Florida Adminstrative Code, exempts existing or proposed installations which FDEP determines "does not or will not cause the issuance of air or water contaminants in sufficient quantity." 58

If an applicant is unable to meet either public interest standard, the FDEP or the governing board of the WMD is to consider measures proposed by or acceptable to the applicant to mitigate adverse effects that may be caused by the regulated activity. These may include onsite mitigation, offsite mitigation, offsite regional mitigation, and the purchase of mitigation credits from permitted mitigation banks. ${ }^{59}$ The nature or location of the mitigation to be considered appears to be the same whether the activity is proposed in a non-OFW or an OFW.

\section{Antidegradation Policy}

As required by the federal Clean Water Act, Florida has adopted an antidegradation policy to prevent the further degradation of the state's waters. In accordance with its regulations,

\footnotetext{
${ }^{56} I d . \S 373.414(\mathrm{a})$.

${ }^{57}$ Florida Power Corporation v. Fla. Dept. Env. Prot., 638 So. 2d 545, 559-60 (Fla. Dist. Ct. App. 1994) (affirming agency final order where agency head rebalanced the findings of fact to determine whether a proposed activity satisfied the public interest test).

58 FLA. AdMIN. CODE r. 62-4.040(1)(b) (2008).

${ }^{59}$ FLA. STAT. § 373.414(1)(b) (2008).
} 
the DEP shall refused to permit any discharge that "will reduce the quality of the receiving waters below the classification established for them." 60 If a proposed discharge will not reduce the quality of the receiving water below its classification, the DEP "shall permit the discharge if such degradation is necessary or desirable under federal standards and under circumstances which are clearly in the public interest, and if all other Department requirements are met." 61

The antidegradation standard does not apply to "any existing activity permitted, exempted, or for which a completed application for permit was filed, on or before the effective date of the [OFW] designation."62 It also does not apply "to any renewal of a Department permit where there is no modification of the activity which would necessitate a permit review. Furthermore, "any activity that is exempted from permit programs administered by the Department is not subject to the requirements" of OFW review. ${ }^{63}$

In determining whether a proposed discharge which results in water quality degradation "is necessary or desirable" or "clearly in the public interest," the DEP must consider and balance the following factors:

- Whether the proposed project is important to and is beneficial to the public health, safety, or welfare;

- Whether the proposed discharge will adversely affect conservation of fish and wildlife, including endangered or threatened species, or their habitats; and

- Whether the proposed discharge will adversely affect the fishing or water-based recreational values or marine productivity in the vicinity of the proposed discharge; and

- Whether the proposed discharge is consistent with any applicable Surface Water Improvement and Management Plan that has been adopted by a Water Management District and approved by the Department. ${ }^{64}$

In addition, the Florida antidegradation policy provides that no permit or water quality certification may be issued for an activity in an OFW unless the proposed activity of discharge is clearly in the public interest and one of two additional factors are met. ${ }^{65}$ Either (1) a permit was issued or application received on or before the date of OFW designation or (2) the existing ambient water quality within the OFW will not be lowered as a result of the proposed activity or discharge. With respect to the second factor, a lowering of water quality may be allowed on a temporary basis during construction within a restricted mixing zone approved for the FDEP, if water quality criteria would not be violated outside the restricted mixing zone. ${ }^{66}$

\footnotetext{
${ }^{60}$ FLA. AdMIN. CODE r. 62-302.300(16) (2008).

${ }^{61}$ Id. r. 62-302.300(17).

${ }^{62}$ Id. r. $62-242(2)(\mathrm{d})$.

${ }^{63} I d$. r. $62-4.242(2)(\mathrm{c})$.

${ }^{64}$ Id. r. $62-4.242(1)(\mathrm{a})$.

${ }^{65}$ Id. r. $62-4.242(2)$.

${ }^{66}$ Id. r. $62-4.242(2)(\mathrm{a})(\mathrm{ii})(1)-(2)$.
} 
"Existing ambient water quality" is "the better water quality of either (1) that which could reasonably be expected to have existed for the baseline year of an Outstanding Florida Water designation or (2) that which existed during the year prior to the date of a permit application." 67 The term "water quality" itself is not defined by Florida law. Water quality standards and water quality criteria are defined terms that suggest the presence of a rulebased list that limits what factors may be considered. ${ }^{68}$ Pollution is defined in a general way, 69 but it appears to be operationalized in the context of violations of water quality standards. ${ }^{70}$ As to the specific requirements for the establishment of data that are baseline water quality, the Department has indicated that any water quality documentation that will help characterize the water is helpful. ${ }^{71}$ The absence of site-specific water quality data for rule-based standards and criteria may make enforcement of the OFW antidegradation standard problematic, and the extent to which unlisted contaminants compromise "existing ambient water quality" as a matter of law has not been addressed.

In limited circumstances, the FDEP may permit activities and discharges in OFWs which allow for or enhance public use, maintain facilities in existence prior to the OFW designation date, or maintain facilities permitted after adoption of the designation. ${ }^{72}$ Such activities may be permitted only if the activity mets the "clearly in the public interest" test and it meets (1) one of the two additional factors outlined above or (2) management practices and suitable technology approved by the Department are implemented for all stationary installations including those created for drainage, flood control, or by dredging or filling and there is no alternative for the proposed project. ${ }^{73}$

\section{Mixing Zones}

An OFW designation also alters the FDEP's authority with respect to mixing zones, which the agency is authorized to establish in certain circumstances. ${ }^{74}$ Mixing zones are areas where discharges may be measured further away from the point source which allows some dilution (and hence water quality degradation) to take place in the receiving water before measurement. ${ }^{75}$ In general, mixing zones are prohibited in OFWs. ${ }^{76}$ Some exceptions apply, however. For example, mixing zones are permitted for sources receiving permits prior to either April 1, 1982 or the designation of the OFW (whichever is earlier), blowdown from new power plants that are certified pursuant to the Florida Electrical Power Plant Siting Act, and discharges of water that are necessary for water management purposes and have been approved by the governing board of a water management district (and the FDEP

${ }^{67}$ Id. r. $62-4.242(2)(\mathrm{c})$.

${ }^{68}$ Id. r. $62-302.200(31)-(32)$.

${ }^{69}$ Id. r. 62-302.200(15) (defining pollution generally).

70 Id. r. 62-302.300(13) ("Pollution which causes or contributes to new violations of water quality standards or to continuation of existing violations is harmful to the waters of this State and shall not be allowed ...”).

71 Personal Communication, Stacey Crowley, Office of General Counsel, Florida Department of Environmental Protection, and Janet Klemm, supra note 10.

72 FLA. Admin. CodE r. 62-4.242(2)(b) (2008).

${ }^{73} \mathrm{Id}$.

${ }^{74}$ FLA. STAT. § 403.061(11) (2008).

75 Fla. Admin. Code, r. 62-302.200(39) (2008).

${ }^{76}$ FLA. STAT. $§ 403.061(11)(\mathrm{b})(2008)$. 
Secretary if required by law). ${ }^{77}$ In addition, mixing zones are allowed for the discharge of demineralization concentrate which is permittable under and meets the criteria of $\S$ 403.0882, Florida Statutes, if the proposed discharge is found to be clearly in the public interest. ${ }^{78}$ The rationale for the adding the "clearly in the public interest" requirement for demineralization concentrate (discharge from desalinization treatment facilities) is unclear, since ERP permits for activities in OFWs must meet that requirement anyway.

\section{B. Wastewater Permits}

\section{Wastewater Discharges}

Under Florida law, no wastes are to be discharged to any waters of the state without first being given the degree of treatment necessary to protect the beneficial uses of such water. ${ }^{79}$ A wastewater permit issued by the FDEP is required for certain construction activities and operations associated with wastewater facilities or activities. ${ }^{80}$ These activities must further conform to a variety of requirements listed in r. 40B-4.2030(8)(d)-(m), Florida Administrative Code.

For purposes of permitting, wastewater facilities or activities are categorized as either industrial or domestic based on the type of wastewater the facility handles. ${ }^{81}$ Domestic wastewater is wastewater from dwellings, business buildings, institutions, and the like, commonly referred to as sanitary wastewater or sewage. ${ }^{82} \mathrm{~A}$ permit is required for the construction, modification, or operation of domestic wastewater treatment and effluent disposal or reuse facilities. ${ }^{83}$ The requirements for the treatment and reuse or disposal of domestic wastewater are set forth in $\S \S 403.085$ and 403.086, Florida Statutes. Minimally, treatment must comply with Technology-based Effluent Limitations ${ }^{84}$ and in certain cases, Water Quality-based Effluent Limitations. ${ }^{85}$ Activities excluded from domestic wastewater permitting requirements are enumerated in r. 62-600.120, Florida Administrative Code.

\footnotetext{
${ }_{77} I d$. at $\S 403.061(\mathrm{~b})(1)-(3)$.

${ }^{78} \mathrm{Id}$. $\$ 403.061(11)(\mathrm{b})(1)(4)$. The blowdown exemption to r. 62-4.242(2), Florida Administrative Code, permit requirements addresses blowdown from a recirculated cooling water system of a steam electrical generating plant in an OFW or significantly degrades an OFW. The FDEP considers issuing a permit for such an activity if one of two standards are met. First, if at the point of discharge, the discharge follows the limitations of $\mathrm{r}$. 62-302.520(4), which stipulate the monthly and maximum temperature limits. Second, a mixing zone is established which follows the requirements of r. 62-302.520(6)(b), ensuring protection of species relying on the OFW, as long as the establishment also considers the recreational and/or ecological significance of the OFW, and the discharge meets the requirements of r. 62-302.520(4) at the boundary of the mixing zone.

79 FLA. STAT. § 403.021(2) (2008).

80 Fla. Admin. Code, r. 62-620.310(1) (2008). Section 403.051(2)(a), Florida Statutes, requires that any Department planning, design, construction, modification, or operating standards, criteria, and requirements for wastewater facilities be developed as a rule.

81 FLA. STAT. §367.021(5) (2008).

82 Id. §367.021(5); FLA. ADMIN. CODE, r. 62-600.200(25) (2008).

${ }^{83}$ Id. r. $62-600.700(1)$.

${ }^{84}$ Id. r. $62-600.420$.

${ }^{85}$ Id. r. $62-600.430$.
} 
All wastewater that is not defined as domestic wastewater is considered industrial wastewater. ${ }^{86}$ Sources of industrial wastewater include large and small facilities and activities such as manufacturing, commercial businesses, mining, agricultural production and processing, and wastewater discharge from cleanup of petroleum and chemical contaminated sites. ${ }^{87}$ There is a general permit for the specific activities categorized as having industrial, as opposed to domestic, wastewater. ${ }^{88}$ Effluent limitations for industrial wastewater discharges are addressed in rule 62-660.400.

For domestic and industrial wastewater discharges, the public interest test outlined above applies as well. ${ }^{89}$ This means that in applying for a domestic or industrial wastewater permit, the applicant must show that the proposed activity is not contrary to the public interest, or in the case of an OFW, that the activity is clearly in the public interest.

\section{General and Generic Permits in OFWs}

The FDEP and WMDs also issue "noticed general permits" for certain types of facilities or activities that have minimal adverse environmental impact when performed in accordance with specific requirements and practices. ${ }^{90}$ Noticed general permits are considered "permits by rule" which means that they are issued upon adoption as a rule pursuant to Chapter 120, Florida Statutes. ${ }^{91}$ Rule 62-34.900, Florida Administrative Code, sets forth the general policies and procedures for the issuance of noticed general permits. Thirty-six activities are currently permitted under this rule.

"Generic permits" are issued by the Department as an alternative to individual permits to regulate a particular category of wastewater facilities or activities. They are also permits by rule. ${ }^{92}$ Generic permits may only be issued if they all: (a) involve the same or substantially similar types of operations; (b) discharge the same types of wastes or engage in the same types of residuals or industrial sludge use or disposal practices; (c) require the same effluent limitations, operating conditions, or standards for residuals or industrial sludge use or disposal; and $(\mathrm{d})$ require the same or similar monitoring. ${ }^{93}$

With respect to general and generic permits, neither the statutes nor implementing rules categorically treat OFWs differently. All anti-degradation standards must be followed, including those concerning OFWs. ${ }^{94}$ Some noticed general permits, however, do give special treatment to OFWs. ${ }^{95}$ More than thirty noticed general permits are listed for FDEP in the

${ }^{86}$ FLA. STAT. §367.021(8) (2008).

87 Florida Department of Environmental Protection, Wastewater Permitting, http://www.dep.state.fl.us/water/wastewater/permitting.htm (last visited Feb. 15, 2010).

88 FLA. ADMIN. CODE rules 62-660.801 - .806, 62-660.820 - .821 (2008).

${ }^{89}$ Id. r. $62-4.242(1)(\mathrm{c})-(\mathrm{d})$.

90 FLA. STAT. §403.814(1) (2008).

${ }^{91}$ Id. §403.814; FlA. AdMIN. CoDE, r. 62-620.705(1) (2008).

92 Id. r. $62-620.710(1)$.

${ }^{93}$ Id. r. $62-620.710(2)$.

${ }_{94} I d$. r. $62-341.215$.

95 See e.g., id. r. 62-341.447(2)(e), General Permit to the Florida Department of Transportation, Counties, and Municipalities for Minor Activities Within Existing Rights-of-Way or Easements: "This general permit shall not apply to ditch construction in Class I or Class II surface waters, 
Florida Administrative Code. ${ }^{96}$ Fifteen of those specifically mention OFWs,${ }^{97}$ although ten simply state that the particular permitted activity is prohibited in OFWs. ${ }^{98}$ Some Water Management Districts also have general permit rules that specifically mention OFWs. ${ }^{99}$ Also, certain permits under FDEP and the Southwest Florida Water Management District require that permit applications specify if the activity will take place in an OFW. ${ }^{100}$

\section{C. $\quad$ Stormwater Management}

Stormwater management is regulated by a number of programs within the FDEP, including Florida's National Pollutant Discharge Elimination System (NPDES) program (as authorized by the Federal Clean Water Act), ${ }^{101}$ and the ERP program. ${ }^{102}$ Stormwater management activities require ERP permits. ${ }^{103}$ Rule 62-25.025, Florida Administrative Code, regulates stormwater management in OFWs.

A construction permit for a new stormwater discharge facility may only be issued by the FDEP if the application provides reasonable assurance that "the construction, expansion, modification, operation, or activity of the stormwater discharge facility will not discharge, emit, or cause pollution in contravention of Department standards, rules or regulations."104 Reasonable assurance is presumed if the facility design will provide treatment equivalent to retention (or detention with filtration) of the runoff from the first one inch of rainfall, or first one-half inch if the drainage areas are less than 100 acres. ${ }^{105}$ Facilities discharging directly into OFWs need to provide an additional level of stormwater treatment "equal to fifty percent of the treatment criteria." 106

Anyone who owns or has authorization to use a wetland for stormwater treatment must obtain a wetlands stormwater discharge facility permit from the FDEP. ${ }^{107}$ Wetlands stormwater discharge facilities must also provide treatment of runoff from the first one inch of rainfall (or the first one-half inch of runoff for drainage areas less than 100 acres). ${ }^{108}$ As with the other stormwater regulations, wetland stormwater facilities directly discharging into OFWs are required to comply with r. 62-25.025(9), Florida Administrative Code.

Outstanding National Resource Waters or waters designated as Outstanding Florida Waters.”

96 See, id, ch. 62-341.

${ }_{97}$ See, id.

${ }^{98} \mathrm{Id}$.

99 The South Florida Water Management District: FLA. AdMIN. CoDE r. 40E-4.301; the Suwannee River Water Management District: FlA. ADMIN. CODE, r. 40B-400.051 and r. 40B-400.215; the Southwest Florida Water Management District: FlA. ADMIN. CoDE, r. 40D-1.603 and r. 40D-400.500. 100 FLA. ADMIN. CODE, r. 40D-1.603(11) and ch. 62-341 (2008).

101 Fla. StAT. $\S 403.0885$ (2008), Fla. Admin. CoDE r. 62-620.100 (2008), 33 U.S.C. $§ 1342$ (2008).

102 Fla. Admin. CODE, r. 62-40.431(3) (2008).

103 FLA. STAT. $\S \S 373.413(2), 373.416,403.812$ (2008).

104 Fla. AdMin. CODE 62-25.040(4) (2008).

${ }^{105}$ Id. r. $62-25.040(5)$.

106 Id. r. $62-25.025(9)$.

107 Id. r. $62-25.042(3)$.

${ }^{108}$ Id. r. 62-25.042(6)(b). 


\section{Docks, Piers, Docking Facilities and Marinas}

Permit applicants seeking to construct a dock generally apply for an ERP permit. However, certain types of dock and docking facilities are exempt from FDEP permitting. For nonOFW waters, permits are only required for docks over 1000 square feet. In an OFW, the exemption is reduced to 500 square feet. ${ }^{109}$ Four separate requirements need to be met to qualify for these exemptions. First, the dock should be used for recreational or noncommerical activities - no commerical activities should take place there. ${ }^{110}$ Second, it should use pilings as support, including floating docks, so that the facility's installation does not involve unnecessary filling or dredging. 111 Third, the facility should not substantially impede the flow of water, create a navigational hazard, or cause water quality violations (which include OFW standards). ${ }^{112}$ Finally, the dock should be the sole dock along the shoreline for a minimum distance of 65 feet. ${ }^{113}$ If the individual parcel of land is less than 65 feet in length along the shoreline, then one dock per parcel will be allowed. In the case of multi-family developments, complexes, or other facilities using the proposed private dock, those structures are treated as one parcel of land, regardless of legal ownership divisions or control of that property.

In Florida, "any development which, because of its character, magnitude, or location, would have a substantial effect upon the health, safety, or welfare of citizens of more than one county" must undergo "development-of-regional-impact" review by the Florida Department of Community Affairs. ${ }^{114}$ Development of regional impact review is required for waterport or marina construction, unless the facility is designed for (1) the wet storage or mooring fo less than 150 watercraft used exclusively for sport, pleasure, or commercial fishing; (2) the dry storage of less than 200 watercraft used exclusively for sport, pleasure, or commercial fishing; or (3) the wet or dry storage or mooring of fless than 400 watercraft used exclusively for sport, pleasure, or commercial fishing with all necessary approvals and located outside OFW and Class II waters. ${ }^{115}$ In addition, the FDEP must determine "that the marina is located so that it will not adversely impact Outstanding Florida Waters or Class II waters and will not contribute boat traffic in a manner that will have an adverse impact on an area known to be, or likely to be, frequented by manatees."116

\section{E. Other Activities}

Although an ERP permit is not require for "the installation, removal, and replacement of utility poles that support telephone or communication cable lines, or electric distribution lines of 35 kilovolts or less," 117 this exemption does not apply to forested wetlands located within 550 feet of the mean high water line of an OFW. ${ }^{118}$ In addition, permit exemptions

\footnotetext{
${ }^{109}$ Id. r. 40B-400.051(2)(g).

110 Id. r. 40B-400.051(2)(g)(1).

111 Id. r. 40B-400.051(2)(g)(2).

112 Id. r. 40B-400.051(2)(g)(3).

113 Id. r. 40B-400.051(2)(g)(4).

114 FLA. STAT. § 380.06(1) (2008).

115 FLA. AdMIN. CODE r. 28-24.034(1) (2008).

116 Id.

117 Id. r. 40B-400.051(2)(v).

118 Id. r. 40B-400.051(2)(v)(4).
} 
for treatment or disposal systems do not affect application of state water quality standards, including those for OFWs. ${ }^{119}$

\section{F. Best Management Practices for Silviculture Operations}

The maintenance of Florida's water quality standards are required during all silviculture operations in the state. ${ }^{120}$ In order to ensure that this goal is reached, the State of Florida has developed and adopted a Best Management Practices (BMPs) manual for silviculture operations and management in order to address these impacts. ${ }^{121}$ Silviculture operations are required to utilize the "Silvicultural Best Management Practices Manual," last revised in 2008. ${ }^{122}$ These BMPs were developed specifically for silviculture and are intended to be applied on all such operations in the state regardless of whether or not the operation is subject to other regulatory standards or permits. ${ }^{123}$ However, these BMPs are not intended for use during tree removal or land clearing operations associated with development or other activities that have non-forestry objectives. ${ }^{124}$

Silviculture operations in Florida are presumed to comply with state water quality standards as long as they provide a notice of intent to implement BMPs on their property and follow the other requirements. These requirements include the maintenance of documentation that verifies the implementation and maintenance of BMPs on the subject property. ${ }^{125}$

Silviculture activities in Florida that are not exempted due to this presumption of compliance must seek and obtain a permit from the appropriate local, state, and/or federal government agency prior to conducting the operation. ${ }^{126}$ Rule 40C-400.500, Florida Administrative Code, dictates when the acquisition of a permit is required for construction, operation, maintenance, alteration, abandonment, or removal of minor silviculture surface water management systems. ${ }^{127}$ For instance, certain activities, such as culvert placement during normal forestry operations, require the landowner to apply for a permit from the appropriate water management district. ${ }^{128}$

The FDEP may establish Special Management Zones (SMZ), specific areas associated with a stream, lake, or other waterbody which are designated for more stringent protection during silviculture operations. ${ }^{129}$ The purpose of an SMZ is to protect water quality by

\footnotetext{
119 Id. r. 40B-400.051(3)(f).

120 Florida DePartment of Agriculture AND Consumer Services, Silviculture Best MANAGEMENT PRACTICES MANUAL, 2 (2003).

${ }^{121} I d$. at 1.

122 Fla. Admin. Code, r. 40C-400 (5)(g) (2008).

123 Silviculture BMP Manual, supra note 125.

${ }^{124} \mathrm{Id}$.

125 Id.

$126 \mathrm{Id}$

127 FLA. AdMin. CODE, r. 40C-400 (2008).

128 See, The St. Johns River Water Management District, Applicant's Handbook for the MANAGEMENT AND STORAGE OF SURFACE WATERS, available at http://www.sjrwmd.com/handbooks/msswhandbook.html (last visited Feb. 26, 2010).

${ }^{129}$ Silviculture BMP Manual, supra note 120, at 3.
} 
minimizing the amount of sediment, nutrients, debris, chemicals, and water temperature changes that can have a negative affect on water quality. ${ }^{130}$ Within the SMZ, there are two sub-zones: a Primary Zone with timber-harvesting restrictions and a Secondary Zone which only imposes operational restrictions. ${ }^{131}$

The Primary Zone is meant to afford water quality protection to the contiguous water bodies by maintaining shade along the banks, minimizing the disturbance to ground cover vegetation, and reducing leaf litter impacts. ${ }^{132}$ The Primary Zone also provides essential wildlife habitat values, particularly for species that need snags, cavities, tall trees, and other characteristics that are often associated with minimally impacted forest conditions. ${ }^{133}$ The width of the Primary Zone is dictated by the width of the water body and the water body's type/classification. ${ }^{134}$ Water bodies less than 20 feet wide have a Primary Zone that is 35 feet wide on each side. ${ }^{135}$ Water bodies whose width is between 20 and 40 feet wide have a Primary Zone that is 75 feet on each side. ${ }^{136}$ Water bodies whose width is $40 \mathrm{ft}$ or wider have a Primary Zone that is 200 feet wide per side. ${ }^{137}$

An OFW designation has the effect of expanding the Primary Zone to 200 feet from the shoreline, even if the width of the waterbody is less than 40 feet. ${ }^{138}$ This expansion of the primary zone can have a more significant effect on silviculture activities on small tributaries, braided streams, and headwaters where Primary Zones may overlap, substantially increasing the area subject to the Zone's restrictions.

Within the Primary Zone clearcut harvesting is prohibited, except under special conditions. These special conditions are:

- No individual tract or tracts-in-contiguous-ownership may be required to designate more than $10 \%$ of the total tract area as Primary Zone;

- No Primary Zone may be required beyond 35 feet from a perennial water body or 50 feet from any OFW, Outstanding Natural Resource Water (ONRW), or Class I Water, where the trees have been traditionally managed for the purpose of pine timber production and where there is an existing predominance of pine trees with no significant component of large sized or merchantable hardwood trees;

- Where the above do not apply, clearcut harvesting in the Primary Zone is permissible provided that no clearcutting takes place within 35 feet of any perennial water body or within 50 feet of any OFW, ONRW, or Class I Water, and where:

\footnotetext{
${ }^{130} I d$.

${ }^{131} \mathrm{Id}$. at 5.

132 Id. at 4 .

${ }^{133} \mathrm{Id}$.

${ }^{134} I d$. at 56.

135 Id.

${ }^{136}$ Id.

137 Id.

${ }^{138}$ Id. at 7 .
} 
- The total acreage clearcut does not exceed $25 \%$ of the area designated as Primary Zone, and the number of acres clearcut are added-on to the Primary Zone acre for acre. These additional acres added-on to the Primary Zone must be directly connected to the Primary Zone boundary within the harvest unit, may not extend out beyond that boundary more than 200 feet, and must be managed in accordance with the Primary Zone Management Criteria;

- The basal area of overstory trees within the SMZ is 30 square feet per acre or less, and other hardwood species present are of such low quality (physiologically or biologically) that total stand removal would provide a greater long-term wildlife and/or forestry benefit. However, the total area clearcut under this exception may not equal more than $10 \%$ of the Primary Zone, and any given clearcut parcel must not be greater than 500 feet in length, as measured along the stream. ${ }^{139}$

In certain circumstances, the second exemption cited above may have significant effects on the primary zone delineation. As stated, this provision exempts tracts of land that have traditionally been managed for the purpose of pine timber from being required to expand their primary zone beyond 35 feet. However, this exception also requires that "there is an existing predominance of pine trees with no significant component of large sized or merchantable hardwood trees." 140 In Florida, a significant percentage of water bodies are lined with large sized or merchantable hardwoods, such as cypress that may extend beyond 35 feet. The presence of these hardwoods may therefore limit the application of OFW BMPs for silviculture adjacent of such water bodies.

The following management criteria apply in Primary Zones:

- Clearcut harvesting is always prohibited within 35 feet of all perennial waters and within 50 feet of all water bodies designated as OFW, ONRW, or Class I Waters.

- Selective harvesting may be conducted to the extent that $50 \%$ of a fully stocked stand is maintained. The residual stand should conform to the following:

- Trees are left to maintain the approximate proportion of diameter classes and species present prior to harvesting, except oaks (other than water oaks) may be favored;

- Repeated entry into harvested Primary Zone in short time intervals for additional harvesting is prohibited;

- No trees are harvested in stream channels or on the immediate stream bank.

- Special emphasis should be given to the following within the Primary Zone:

- Protection of very large and/or old trees

- Protection of snags (dead trees) and cavity trees

- Protection of trees where any part of the canopy overhangs the water

${ }^{139} I d$. at 105.

${ }^{140} \mathrm{Id}$. 
- The following forestry activities are prohibited within the Primary Zone:

- Mechanical site preparation;

○ Fertilization;

- Aerial application or mist blowing of pesticides (herbicide, fungicide, insecticide);

- Loading decks or landings and log bunching points;

- Road construction except when crossing a water body;

○ Site preparation burning on slopes greater than $18 \%$ perennial. ${ }^{141}$

The Secondary Zone may apply as an "add-on" to the SMZ depending on certain characteristics of the site including the soil erodibility, K-factor (index representing the potential erodibility of a soil by water based on soil texture), and the slope of the site. ${ }^{142}$ Depending on soil and site characteristics, the Secondary Zone may be extended up to an additional one hundred feet. ${ }^{143}$

The Secondary Zone has no timber harvesting restrictions. However, the following operational restrictions apply:

- No mechanical site preparation;

- No loading decks or landings;

- No site prep burning on slopes exceeding 18\%;

- No roads except for crossings ${ }^{144}$

\section{G. Submeged Lands Authorizations}

The State of Florida typically owns the lands beneath surface waters. ${ }^{145}$ When this is the case, additional authorizations are required to conduct activities that are subject to permitting. This ordinarily comes in the form of a lease or "consent of use."146 ERPs and submerged lands authorizations (SLAs) are ordinarily consolidated into a single application. Activities that are to be conducted over sovereign submerged lands are subject to their own public interest standard. ${ }^{147}$ For most submerged lands, this standard is the same as for non-OFW waters; the proposed activity must be "not contrary to the public

\footnotetext{
${ }^{141} I d$. at $4-5$.

${ }^{142} I d$. at 5.

143 Id. at 43.

${ }^{144}$ Id. at 5.

145 FLA. STAT. $§ 253.001,253.002$ (2009).

146 See generally, id. ch. 253.
}

147 When used in the context of submereged lands authorizations, 'Public interest' means demonstrable environmental, social, and economic benefits which would accrue to the public at large as a result of a proposed action, and which would clearly exceed all demonstrable environmental, social, and economic costs of the proposed action. In determining the public interest in a request for use, sale, lease, or transfer of interest in sovereignty lands or severance of materials from sovereignty lands, the Board shall consider the ultimate project and purpose to be served by said use, sale, lease, or transfer of lands or materials.” FLA. ADMIN. CODE r. 18-21.003(51)(submerged lands generally), r. 18-20.003(46) (aquatic preserves). 
interest." 148 However, when the proposed activitiy falls within one of Florida's forty-one aquatic preserves, the standard becomes "in the public interest."149

Rules governing submerged lands and aquatic preserves address the public interest standard differently from the rules governing OFWs. To be considered "in the public interest" for the purposes of SLAs, a balancing test is employed to determine whether the benefits of the proposed activity outweigh its costs. ${ }^{150}$ The benefits and costs to be considered relate to improvements to the social, economic, and/or environmental condition of the aquatic preserve. What appears to be critical here, is that for SLAs, mitigation that merely offsets impacts may be insufficient. Whereas, if the proposed activity lies within an aquatic preserve the applicant must do more than merely offset the impacts of the activity to demonstrate the project is "in the public interest." 151

All aquatic preserves in Florida are also managed-waters OFWs. ${ }^{152}$ Thus in addition to meeting the public interest test of the SLA for aquatic preserves, such activities must also meet the heightened standard of "clearly in the public interest" for permitting in OFWs. However, the OFW rules do not offer the same sort of detailed guidance through a public benefits balancing test. As a result, greater attention is paid to the role of mitigation in demonstrating that an activity is "clearly in the public interest," but there remains little clarity as to the distinction between mitigation that satisfies the "not contrary to the public interest" test and mitigation that rises to the level of "clearly in the public interest." Florida judicial and adminstrative case law has not been particularly helpful in parsing this distinction.

\section{Florida Case Law Addressing OFWs}

Only one appellate case squarely addresses OFWs. The preponderance of judicial treatment comes from administrative decisions where administrative law judges (ALJs) review an agency action on a permit application for an activity that affects an OFW. These cases tend to be fact specific and do little to clarify the legal standards governing review of permits for activities in OFWs, particularly the crucial determination as to what contitutes "signficant degradation," and when an activity is "clearly in the public interest."

The leading case involving an OFW remains 1800 Atlantic Developers v. Department of Environmental Regulation, 552 So. 2d 946 (Fla. Dist. Ct. App. 1989). ${ }^{153}$ In 1800 Atlantic, the Department of Environmental Regulation (DER) (DEP's predecessor agency) had adopted a final order to deny a dredge and fill permit on land in Key West owned by 1800

148 Id. r. 18-21.004(a) (“... all activities on sovereignty lands must be not contrary to the public interest, except for sales which must be in the public interest.").

149 Id. 18-20.004(1)(b) ("There shall be no further sale, lease or transfer of sovereignty lands except when such sale, lease or transfer is in the public interest ...").

150 FLA. StAT. §373.414 (2008), FlA. AdMIN. CodE, r. 62-302.700(1) and r. 62-4.242(2)(a)(ii) (2008).

${ }^{151} \mathrm{Id}$.

${ }^{152}$ Id. r. 62-302.700(2)(f) (2008).

1531800 Atlantic Developers v. Department of Environmental Regulation, 552 So. 2d 946 (Fla. Dist. Ct. App. 1989). 
Atlantic Developers. ${ }^{154}$ The permit denial was based upon the fact that the DER had recently designated the waters in that area of Key West to be an OFW. ${ }^{155}$ Therefore, the heightened "clearly in the public interest" test was applied and the DER found the proposed activity not clearly in the public interest. ${ }^{156}$

The appellate court reversed the DER's final order, finding that the DER should have afforded 1800 Atlantic Developers an opportunity to explain which changes to the permit application could warrant DER's approval of the proposed project, as instructed by $\S 403.92$, Florida Statutes. ${ }^{157}$ The court opined:

Absolute prohibition of dredge and filling activity, therefore, should be the rare exception in cases of extreme damage to the environment that cannot be avoided or mitigated under any circumstances. It must be remembered that this act was not intended to serve as a means for the state to acquire private land for public purposes, or to compel the owner of private land to make it available for the public use and benefit, without the state's having to pay just compensation to the owners. ${ }^{158}$

Further, the court found that the DER erred in adopting the hearing officer's recommendation to deny the permit based on "vague and ill defined" additional conditions in the mitigation agreement. ${ }^{159}$ While the DER believed the hearing officer's conclusions were findings of fact and therefore binding on the department, the court explained that the DER itself, not the hearing officer, was responsible for considering and determining the appropriateness of mitigation measures. ${ }^{160}$ The second sentence in the quoted language above is significant because it appears to undercut reliance on the sorts of public benefits that serve as the basis for the conclusion that an aquatic preserve submerged lands authorization is "in the public interest." It also makes it difficult to utilize the nature and form of mitigation to distinguish between activities in OFWs and non-OFWs and their respective public interest tests, e.g. mitigation that does more than merely offset impacts.

\section{Florida Administrative Case Law Addressing OFWs}

113 administrative cases involving OFW permitting were reviewed for this article, including ERPs, wastewater, and stormwater permits. (See Appendix A). Of these, 59 permits were approved and 54 denied. Within the various categories of permitted activities subject to OFW review, the proportions were roughly equivalent. A wide variety of activities under ERPs were reviewed, including dredge and fill permits for docks, marinas, boat slips; developments of regional impact; and seawalls. In reviewing the administrative decisions as a whole, no single permitted activity was approved or denied more often than others. Appendix A provides a thorough review of each of these cases in terms of the activity

\footnotetext{
154 Id. at 950.

$155 \mathrm{Id}$. at 948.

${ }^{156} I d$. at 950.

$157 \mathrm{Id}$. at 955.

158 Id. at 954-955.

159 Id. at 955 .

160 Id.
} 
permitted, the issue, holding and, where evident, the reasoning. In addition, the nature of any mitigation proposed is described.

The particular type of permit did not seem to be an important factor. The driving force behind whether any activity was allowed or prohibited really depended on the specific facts of the case. In reviewing the 113 cases, several facts seem particularly important. First, a highly prestine or unique OFW tended to weigh against the applicant, often ending in a denial of the permit. Whereas, permits that sought activities similar to those already allowed within the same (or similar) OFWs, such as the construction of a standard dock in an OFW where all adjacent landowners also had docks, tended to lead to permit approval. As will be discussed below, the type of activity itself is often very persuasive in the issuance or denial of a permit. Sometimes whether the project would have cumulative and/or secondary impacts was weighed heavily by the Administrative Law Judge (ALJ) and other times it was seemingly ignored.

Another factor that is hard to quantify was the impact of an applicant's willingness to amend their initial permit/project/activity when forced or faced with oppossition by the FDEP or WMD. Often, the FDEP issuance of a "noticed intent to deny" was enough motivation for applicants to completely overhaul their project to better comply with the "clearly in the public interest test." Similarly, another not unappreciated factor, was individual applicants willingness, ability, and preparation to make their project not only comply but go above and beyond the minimum requirements. Finally, the "human factor" and individual biases of ALJs undoubtebly played a role in whether, at least in a few cases, permits were granted or denied. The following sections will explore the dynamics of these various facts in more detail.

\section{A. Reasonable Assurance and the Clearly in the Public Interest Test}

As mentioned above, ERP applicants must provide "reasonable assurance" that the proposed activity will meet the applicable public interest test. For an OFW, this standard is "clearly in the public interest." 161 Florida Audubon Society, Inc. v. South Florida Water Management District and Lennar Homes, Inc. (2002) addressed this "reasonable assurance" standard for an OFW application. The ALJ stated that courts have extended considerable deference to the FDEP and that the decision of whether or not the applicant has provided reasonable assurance that an activity is "clearly in the public interest" is a conclusion of law. ${ }^{162}$ The ALJ in Florida Audubon Society also held that courts should give the same deference to the adequacy of proposed mitigation as they do for the "reasonable assurance" standard. 163

161 FLA. STAT. §373.414 (2008).

162 See, 1800 Atlantic Developers v. Department of Environmental Regulation, 552 So. 2d 946 (Fla. Dist. Ct. App. 1989) and Deep Lagoon Boat Club, Ltd. v. Sheridan, 784 So. 2d 1140 (Fla. Dist. Ct. App. 2001), as cited in Florida Audubon Society, Inc., Fla. Div. of Admin. Hearings Case No. 02-1629 (2002).

${ }_{163}$ Florida Audubon Society, Inc., Case No. 02-1629. See also, Anna Maria, Inc. v. Department of Transportation, 700 So. 2d 113, 116 (Fla. Dist. Ct. App. 1997); 1800 Atlantic Developers, 552 So. 2d 946). 


\section{B. The Role of Mitigation}

Pond, Inc. V. Department of Environmental Protection (1994) examined the role of mitigation in meeting the "clearly in the public interest" test. ${ }^{164}$ This case involved a dredge and fill permit to build a bridge in a Class II OFW, and provides an example of a case where "reasonable assurance" was not provided due to inadequate mitigation. ${ }^{165}$ In the order, the ALJ noted that "Because there will be adverse impacts to an OFW, the project can be permitted only if it is determined that the mitigation plan offsets the adverse impacts and makes the project clearly in the public interest." 166 Despite the applicant's previous belief that the revised project, including a mitigation plan, would be "clearly permissible," the ALJ found the mitigation plan was not adequate, and therefore the applicant did not provide the essential reasonable assurance for the permit to be approved. ${ }^{167}$ The ALJ did not provide a specific reason as to why the plan was inadequate, other than to point out the numerous adverse impacts that the project would have on area wetlands and wildlife. ${ }^{168}$

In the majority of cases in which the permit was approved, however, the applicant showed with reasonable assurance that the activity would meet the clearly in the public interest standard. This finding of reasonable assurance was generally attributed to the adequacy of the mitigation plans, as interpreted by a WMD Governing Board or the FDEP.

Crouthers v. J.B.'s Fish Camp and the Environmental Protection Department (1997) reveals the effect of an applicant's willingness to mitigate on the issuance of the permit. ${ }^{69}$ Crouthers involved a permit for the construction of a sixteen-slip dock, linking to the applicant's existing fish camp, which had two existing docks. ${ }^{170}$ The previously denied application was re-evaluated when the applicant took extensive mitigation efforts and established a conservation easement over a portion of the property. ${ }^{171}$ After adequate mitigation measures were provided, the permit was approved for the dock, even though the docks were proposed within a manatee zone. ${ }^{172}$

\section{Nature of the Activity}

Another important issue addressed in various OFW administrative cases is the nature of activities which meet the "clearly in the public interest" test. Projects that serve a public purpose such as transportation projects and public boat ramps or marinas, may be more likely to meet this threshold since they begin with a presumption that the activity is in the public interest. Even here, however, there may be competing public interests. In Lineberger v. Prospect Marathon Coquina (2008), the FDEP found that even after offsetting the direct impacts of a sixty slip marina project with mitigation, an offer to contribute to the construction of a public boat ramp did not shift the activity to one that is "clearly in the

\footnotetext{
164 Alden Pond, Inc., Fla. Div. of Admin. Hearings Case No. 93-6982 (1994).

165 Id.

166 Id.

167 Id.

168 Id.

169 William and Jill Crouthers, Fla. Div. of Admin. Hearings Case No. 97-0994 (1997).

${ }^{170} \mathrm{Id}$.

${ }_{171} I d$.

172 Id.
} 
public interest," due to the secondary adverse impacts the additional boat traffic from the new ramp would cause. ${ }^{173}$ In State D.O.T. v. St. John's River Water Management District (1996), the District reversed a hearing officer's finding that a proposed transportation project was clearly in the public interest "on the ground that even though replacing a causeway with a permanent bridge may improve existing water quality, the permanence would preclude future restoration of the water body at issue." 174 Additionally, a permit for a proposed bridge was denied in Vanwagoner v. Department of Transportation and Department of Environmental Protection (1995), based on the evidence failing to show that the project would not degrade an OFW. ${ }^{175}$

Several cases have approved the issuance of a permit to applicants proposing relatively minor activities on OFWs, such as public boat ramps, ${ }^{176}$ boat slips, ${ }^{177}$ or the maintenance of mangrove trees ${ }^{178}$. However, permits for such minor activities have also been denied. ${ }^{179}$ For instance, in Town of Windermere v. Orange County Parks and Recreation Department and South Florida Water Management District (1990), the ALJ found that the dredge and fill permit for the floating dock inadequately addressed the water quality issues because of dredging within the OFW.

Suto v. Celebrity Resorts, Inc. and DER (1991) addressed the issue of OFW designation and wastewater permits. ${ }^{180}$ Celebrity Resorts had applied for a permit to construct a wastewater treatment and reuse/disposal facility on Orange Lake, an OFW. ${ }^{181}$ The treatment facility would serve a proposed recreational vehicle (RV) park. ${ }^{182}$ Various constituents who use the lake for professional and recreational activities, as well as for drinking water, opposed the issuance of the permit to Celebrity. ${ }^{183}$ The ALJ, however, recommended that the permit for the proposed sewage treatment plant and effluent disposal system, or spray irrigation system, be granted to Celebrity. ${ }^{184}$ The ALJ explained that Celebrity had provided reasonable assurance that both the sewage treatment plant and the spray irrigation system would not violate any state water quality standards, including the requirement for OFWs that existing ambient water quality not be lowered. ${ }^{185}$

D. "Significantly Degrades" and Geographic Proximity

${ }^{173}$ Linberger v. Prospect Marathon Coquina, Fla. Div. Admin. Hearings Case no. 07-3757, FDEP Consolidated Final Order (2008).

${ }^{174}$ Fla. Dept. of Transportation v. St. John's River Water Management District, Fla. Div. of Admin. Hearings Case no. 94-5261, Recommended Order (1996).

175 Robert E. Vanwagoner, Fla. Div. of Admin. Hearings Case No. 95-3621 (1995).

176 James E. Slater, as Trustee, and Alicia O’Meara, Fla. Div. of Admin. Hearings Case No. 97-0437 (1998).

177 Harold and Charlottee Toms, Fla. Div. of Admin. Hearings Case No. 93-5724 (1994).

178 Leland D. Egland, Fla. Div. of Admin. Hearings Case No. 88-3530 (1988).

179 Town of Windermere, Fla. Div. of Admin. Hearings 90-1782 (1990).

180 Suto, Fla. Div. of Admin. Hearings Case No. 91-2722 (1991).

${ }^{181} \mathrm{Id}$.

182 Id.

183 Id.

${ }^{184} I d$.

${ }^{185} I d$. 
A few cases have addressed the "significant degradation" standard for activities outside of OFWs. ${ }^{186}$ Such activities are subject to the "not contrary to the public interest" test for nonOFWs, but still must demonstrate that they will not "signficantly degrade the OFW. ${ }^{187}$ For example, in Florida Audubon Society, Inc. v. South Florida Water Management District and Lennar Homes, Inc. (2002), Lennar Homes filed an ERP application for a 516-acre residential development, in close vicinity to the Biscayne Bay Coast Wetlands project in Miami-Dade County. ${ }^{188}$ While Biscayne Bay is an OFW, Lennar Homes was able to show that their project was neither directly in an OFW (Biscayne Bay), nor would result in direct discharge of surface water into an OFW. ${ }^{189}$ Therefore, the ALJ did not find reason to deny the permit based on impacts to an OFW. ${ }^{190}$

In Guttmann v. Department of Environmental Protection and ADR of Pensacola (2000), Guttmann objected to a proposed 30-slip docking facility by the applicant, ADR of Pensacola. ${ }^{191}$ Among other things, Guttmann claimed that the activity's discharge, although not directly in the OFW, would significantly degrade it. ${ }^{192}$ The ALJ concluded that since the FDEP had already found the activity would not degrade the Class III waters on which it was located, it also would not significantly degrade the OFW into which the Class III water discharged. ${ }^{193}$ One the other hand, in Sunset Acres Property Owners Association $v$. Department of Environmental Protection (1996), a dredge and fill permit was requested to connect a canal network in the Sunset Acres subdivision to Florida Bay, an OFW.194 According to the ALJ, the applicant Sunset Acres did not provide reasonable assurance that the activity on the non-OFW water would not degrade the OFW. ${ }^{195}$ Therefore, the permit was denied. ${ }^{196}$

Various other administrative cases involve the denial or approval of a permit in an OFW based either solely or partially on the fact that the activity significantly degraded the water quality. ${ }^{197}$ In many of these cases, the ALJ simply made a determination based on the facts that the applicant had or had not provided reasonable assurances that the water quality would not be degraded. However, none of these cases illuminate a specific standard or definition for the phrase "significantly degrades." The Office of General Counsel for the

186 See, Charles H. Griffin, Fla. Div. of Admin. Hearings Case No. 98-0818 (1998) and Florida

Audubon Society, Inc., Fla. Div. of Admin. Hearings Case No. 02-1629 (2002).

187 FlA. AdMin. CODE, r. 62-4.242(2)(a) (2008).

188 Florida Audubon Society, Inc., Fla. Div. of Admin. Hearings Case No. 02-1629 (2002).

189 Id.

$190 \mathrm{Id}$.

${ }^{191}$ Michael L. Guttmann, Fla. Div. of Admin. Hearings Case No. 00-2524 (2000).

192 Id.

${ }_{193} I d$.

194 Sunset Acres Property Owners Association, Fla. Div. of Admin. Hearings Case No. 91-7958 (1996).

195 Id.

${ }^{196} \mathrm{Id}$.

197 See, Manasota-88, Inc. and Manatee County Save Our Bays Association, Inc., Fla. Div. of Admin. Hearings Case no. 90-2350 (1990), Jeffrey Jay Frankel, Fla. Div. of Admin. Hearings, Case No. 981326 (1998), Pine Island Properties, Ltd., Fla. Div. of Admin. Hearings, Case No. 93-2713 (1994), Bay Oaks Circle Association, Inc., Fla. Div. of Admin. Hearings Case No. 99-0851 (1999), Robert E. Vanwagoner, Fla. Div. of Admin. Hearings Case No. 95-3621 (1995), Ocean Reef Club, Inc., Fla. Div. of Admin. Hearings Case No. 87-4660 (1988). 
FDEP has indicated that some permit programs, i.e. industrial wastewater, use the term "measurable" to interpret the meaning of the term "significant."198 Presumably, this means that the effect on ambient water quality can be quantified in some way.

\section{Impact of OFW Designation on Transboundary Waters}

Florida shares a number of water bodies with its neighboring states, several of which are OFWs. These waters are commonly referred to as successive and contiguous, depending on their relationship as an interstate boundary. ${ }^{199}$ Successive water bodies such as the Apalachicola and Suwannee Rivers (both OFWs) flow across a state border as they progress downstream. Contiguous water bodies, like the Perdido River (an OFW), flow along a state border as they progress downstream, typically with the centerline of the stream serving as the political boundary. ${ }^{200}$ The presence of these types of rivers in Florida creates unique circumstances when that river is designated as an OFW.

The transboundary nature of the Apalachicola River, shared between Florida, Alabama and Georgia has generated controversy concerning its use and regulation. ${ }^{201}$ This controversy stems from Georgia and Alabama's interest in the river as a source of drinking water and hydropower, and Florida's interest in the river's environmental characteristics, especially its estuary, renowned for its oysters which are a very profitable industry in the area. ${ }^{202}$ The controversy entered the courtroom years ago and has not yet been resolved. In 2009, a federal district court ordered the U.S. Army Corps of Engineers (Corps) to seek authorization from Congress before changing the project purposes for Lake Lanier, at Apalachicola's headwaters. Georgia seeks to divert water from the lake for potable water use for the metropolitan Atlanta region. ${ }^{203}$

198 Personal Communication, Stacey Cowley, Office of General Counsel, Florida Department of Environmental Protection

199 Stephen C. McCaffrey, The LaW of International Watercourses: Non-navigational Uses, 41 (Oxford University Press, 2001).

$200 I d$.

201 Florida Department of Environmental Protection, Apalachicola-Chattahoochee-Flint River System (ACF) Timeline of Action As of July 27, 2009, http://www.dep.state.fl.us/mainpage/acf/timeline.htm (last visited Feb. 26, 2010).

${ }^{202}$ Kevin Spear, Atlanta's Thirst Risks Florida Way of Life, ORLAndo SEnTINEL (Florida), Oct. 28, 2007 , at A1.

203 The states brought a Joint Motion for Partial Summary Judgment, challenging 'the Corps' operation of Lake Lanier for the benefit of municipal and industrial ... water supply rather than the three authorized purposes for which Congress approved the reservoir's construction - power generation, downstream navigation support, and flood control." On May 11, 2009, Florida and the other parties from the seven consolidated cases presented oral arguments on the motions filed in January before Senior U.S. District Judge Paul Magnuson. On July 27, 2009, Judge Magnuson charged Congress with the responsibility of approving the water use of Lake Lanier for water supply purposes. Additionally, Judge Magnuson ordered that all water withdrawals be frozen at current levels for the next three years until Congressional authorization is given or if some other resolution is reached. If Congress does not approve a reallocation within that period, then water withdrawals from Lake Lanier will revert to "baseline" operation of the mid-1970s. FDEP Timeline, supra note 201. See also, In re Tri-State Water Rights Litigation, 639 F.Supp.2d 1308 (M.D. Fla. 2009). 
Florida, among other things, argues that the Corps has not adequately provided a "required consistency determination" on their actions in relation to the "enforceable policies of the federally approved Florida Coastal Management Plan." 204 In listing the exact enforceable policies that they are referring to, Florida cites to the Florida Statutes and Administrative Code that apply to OFWs, pointing out that the Apalachicola River and Bay are both OFWs. ${ }^{205}$

Contiguous water bodies invoke similar issues for OFWs, which can persist along the entire length of the river. This geographical orientation occurs with the Perdido River, an OFW206 and the St. Marys River, a non-OFW. The Perdido River serves as the border between Florida and Alabama in northwest Florida. Similarly, Florida shares the St. Marys River with Georgia in northeast Florida. Although the two states share the rivers, they may have significantly different management goals and water quality standards. This differential regulation may undermine the purpose of one state's regulatory regime, and hence implicate federal law.

In Arkansas v. Oklahoma, ${ }^{207}$ Arkansas sought a domestic wastewater discharge permit from the EPA. The discharge was to occur in the Illinois River, thirty-nine miles upstream from the Oklahoma state line. Oklahoma challenged the permit on grounds that the proposed discharge violated Oklahoma's water quality standards. After an administrative hearing, the EPA overruled the administrative law judge and issued the permit. When it reached the U.S. Supreme Court, the Court held that while the Clean Water Act does not require compliance with the affected state's water quality standards, it does not preclude EPA from requiring it. EPA rules provide that source states must meet the water quality standards of all affected states. ${ }^{208}$

\section{Key Issues in OFW Regulation and Enforcement}

\section{A. "Contaminants of Emerging Concern"}

The presence of emerging water quality contaminants, such as pharmaceutical products, endocrine disruptors, and nano-materials, has garnered recent attention 209 The continued practice of introducing pharmaceutical products into the waste stream through discharge of expired drugs as well as through treated human waste has introduced the term

${ }^{204}$ In Re Tri-State Water Rights Litigation, Joint Motion and Memorandum in Support of Joint Motion for Partial Judgment on All Phase I Claims, Case no. 3:07-MD-1-PAM, at 72, 73, (M.D. Fla. Jan. 31, 2009), available at http://www.dep.state.fl.us/mainpage/acf/files/012309_summary_judgment.pdf . 205 Id. at 72.

206 FLA. Admin. CoDE, r. 62-302.700(9)(i) (2008). The Perdido River was designated as a special water OFW when the program began in 1978.

207 Arkansas v. Oklahoma, 503 U.S. 91 (1992).

20840 CFR $\S 122.4(\mathrm{~d})$ (2008)(No permit may be issued "when the imposition of conditions cannot ensure compliance with the applicable water quality requirements of all affected States.").

209 Probe: Pharmaceuticals in Drinking Water, CBS News/Associated Press, March 10, 2008, available at http://www.cbsnews.com/stories/2008/03/10/health/main3920454.shtml . 
"contaminants of emerging concern" into the lexicon of water quality protection. ${ }^{210}$ Trace amounts of these pharmaceuticals are too small for the various stages of required water treatment that prevent degradation and end up in the waters of the State of Florida. ${ }^{211}$ These contaminants could lead to the degradation of not only water quality, but may also affect wildlife. While the effects of the introduction of trace amounts of these chemical and biological agents into the water supply is widely unknown, there is also increasing concern about their introduction into aquatic systems through point and non-point source discharges. ${ }^{212}$

An example of the presence of these contaminants in a Florida OFW can be seen in Biscayne Bay. A recent study compared the presence of twenty-four pharmaceutical compounds in Chesapeake Bay, Biscayne Bay, and the Gulf of Farallones. ${ }^{213}$ Results showed that the most contaminants were found in the Chesapeake Bay test sites, which were in close proximity to (adjacent to and downstream of) wastewater treatment plants. ${ }^{214}$ However, the test sites in Biscayne Bay were not near treatment plants; rather, they were "at the mouth of drainage canals and offshore areas that might be affected by inputs from the drainage canals or possibly groundwater discharges." ${ }^{215}$ This concern could be exacerbated if proposals to reduce salinity in the Bay by introducing treated "reuse" water are carried forward. ${ }^{216}$

Emerging contaminants of concern are not currently listed in the published list of water quality criteria to which water quality standards apply. ${ }^{217}$ Even so, under the FDEP's rule, discharges to OFWs may not reduce "existing ambient water quality," except on a temporary basis within mixing zones. The phrase does not limit the determination of ambient water quality to only those parameters that are listed by rule. ${ }^{218}$ Presumably,

210 Environmental Protection Agency, Contaminants of Emerging Concern, Aquatic Life, Water Quality Criteria (2008), available at http://www.epa.gov/waterscience/criteria/aqlife/cec.html.

${ }^{211}$ CBS News, supra note 209.

212 Barbara S. Minsker, Drinking Water Contamination Transcript, March 10, 2008, available at http://www.washingtonpost.com/wp-dyn/content/discussion/2008/03/10/DI2008031002217.html; See also, EPA, supra note 210.

213 Anthony S. Pait, et al., Human Use Pharmaceuticals in the Estuarine Environment: A Survey of the Chesapeake Bay, Biscayne Bay AND Gulf of the Farallones, NOAA Technical Memorandum NOS NCCOS 7 (2006), available at

http://ccma.nos.noaa.gov/publications/humanusepharma.pdf.

214 Id. at 18.

$215 \mathrm{Id}$.

216 See U.S. Geological Survey, Science Plan in Support of Ecosystem Restoration, PRESERVATION, AND PROTECTION IN SOUTH FlORIDA, available at http://sofia.usgs.gov/publications/reports/doi-science-plan/waterparksbaykeys.html (describing a pilot project under the Comprehensive Everglades Restoration Act (CERP) "to determine the ecological effects of using superior, advanced treated reuse water to replace and augment freshwater flows to Biscayne Bay and to determine the level of superior, advanced treatment required to prevent degradation of freshwater and estuarine wetlands and nearshore waters. The constituents of concern in wastewater will be identified, and the ability of superior, advanced treatment to remove those constituents will be determined.")

217 FLA. ADMIN. CODE r. 62-302.530.

218 Ambient water quality is defined in the OFW Rule in a way that does not limit it to specific parameters. 
then, the degradation of water quality by constituents not currently listed by rule could still result in a violation of the $\mathrm{OFW}$ antidegradation rule. This question has not been addressed under Florida law.

\section{B. Riparian Buffers - Are BMPs enough Protection for OFWs?}

Riparian buffers provide a transition between a water body and adjacent uplands. A buffer can have several distinct, yet related, purposes. A buffer protects the water quality through contaminant filtration and the trapping of sediments. A riparian buffer can also provide important habitat. Upland species may depend on riparian corridors for regional movement and other essential needs. Aquatic and wetland-dependent species may utilize riparian buffers for breeding, feeding and shelter during parts of their life cycle. Buffers may also shelter wildlife from disturbance by noise, lights or other consequences of human activities. Riparian buffers thus contribute to the maintenance of a fully functional ecosystem that encompasses the water body and its adjacent uplands. Finally, the recreational value of water bodies may be protected from aesthetic degradation by maintenance of undisturbed native vegetation in riparian buffers. The buffers required to protect water quality are ordinarily narrower than those required for habitat protection.

OFW rules do not consider riparian buffers, except where silvicultural activities are implicated. Silviculture BMPs for both OFWs and non-OFWs incorporate buffers that seem largely focused on protecting water quality, though with widths substantially less than some studies recommend. ${ }^{219}$ To the extent that OFW designation is intended to protect water quality this seems appropriate. However, OFWs include a great diversity of waters in public ownership and "Special Waters" may be designated for their "outstanding ecological and recreational significance." 220 The definition of "outstanding ecological significance in particular suggests that an OFW so designated is "part of an ecosystem of unusual value ..."221 The basis for OFW designation is thus broader than protection of water quality and the qualities that may have lead to OFW designation cannot be maintained unless the watershed is managed with a more comprehensive set of goals. To the extent riparian uplands contribute to the ecological and recreational significance of an OFW, those values and functions should be protected.

The St. Marys River Watershed Report references a methodology for determining buffer widths, developed by the University of Florida's Center for Wetlands. ${ }^{222}$ This study, the "Wekiva River Basin Buffer Study," suggests a science-based methodology focused on targeting significant species of animals and plants and then evaluating their buffer

${ }^{219}$ For a comprehensive review of the scientific and management literature on riparian buffers, see

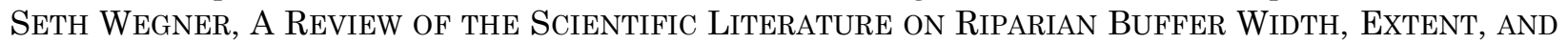
VEGETATION (1999), available at

http://www.rivercenter.uga.edu/service/tools/buffers/buffer_lit_review.pdf

220 FLA. AdMIN. CODE, r. 62-302.200(11 \& 12) (2008).

221 Id. r. 62-302.200(11) (2008).

222 Susanna Blair, et AL., St. Marys River Watershed Report: An AdAPtive Management ASSESSMENT, 42 (2009), available at http://www.law.ufl.edu/conservation/resources/resources.shtml. See also, M.T. Brown, ET AL., An Evaluation of the APPliCABILITY of UPLAND BufFERs For THE Wetlands of the WeKiva Basin, Final Report to the St. Johns River Water Management DisTRICT (1987) a vailable at http://www.cfw.ufl.edu/publications.shtml\#R. 
requirements to ensure their protection. ${ }^{223}$ For example, studies indicate that buffers in wetlands should range from 322 feet to over 550 feet, while buffers in estuaries should be at least 322 feet with no maximum range indicated. ${ }^{224}$ These suggested buffer ranges are typically wider than those afforded by silivcultural BMPs for both OFWs and non-OFW waters, and also exceed most riparian buffers required by local governments. The St. Johns River Water Management District has adopted rules protecting both wetland and upland habitat for aquatic and wetland-dependent species in Riparian Habitat Protection Zones in the Wekiva River, Econlockhatchee River, Tomoka River and Spruce Creek hydrologic basins. ${ }^{225}$ These rules prohibit projects from adversely affecting the "abundance, food sources, or habitat" values for such species within areas, including uplands, that extend as far as 550 feet landward of a stream's edge. ${ }^{226}$

\section{Impairment and $O F W_{S}$}

The federal Clean Water Act requires states to identify water bodies whose water quality does not meet the beneficial use classification that they have been given under the state program, based on the water quality standards and criteria assigned for that classification. ${ }^{227}$ Water bodies that do not meet water quality standards must be designated as impaired and a "total maximum daily load" (TMDL) must be assigned for the violation of those standards that cause the impairment. ${ }^{228}$ The assignment of a TMDL is designed to return the water body to the standards for the use for which it is classified. All water bodies in Florida are assigned to a class. OFWs serve as an overlay on the existing classification system. Hence, all OFWs also have an underlying beneficial use classification, but are not themselves considered a designated use by the state.

OFWs can also be impaired waters, either because they failed to meet water quality standards for their underlying classification when they were designated or because they have been subsequently degraded, notwithstanding the OFW non-degradation standard. However, because OFWs are not listed as designated uses it would appear that they could not be designated as impaired unless the underlying classification of the water body is itself impaired. This means that OFWs whose ambient water quality has been degraded below the quality established at or prior to the designation, but not to a point that the underlying use is impaired, do not trigger the establishment of TMDLs and the restoration planning that is accorded to impaired non-OFWs.

\section{Conclusion}

The ability of current OFW regulation to fulfill the legislative intent behind the OFW designation remains uncertain. Judicial and administrative case law addressing OFWs provide little clear guidance in interpreting the statutory standards for the issuance of permits in or affecting OFWs, especially the "clearly in the public interest" standard. The FDEP should consider adopting for the OFW Program the type of public interest

\footnotetext{
223 Id.

224 Id.

225 See, Fla. Admin. Code. ch. 40C-41 (2008).

226 See, e.g., id. r. 40C-41.063(3)(e).

22733 U.S.C. $\$ 1313(\mathrm{~d})(1)(\mathrm{A})(2008)$.

228 Id. $\S 1313(\mathrm{~d})(1)(\mathrm{C})$.
} 
benefits/costs balancing test currently provided for in Aquatic Preserves Program rules. This test creates a discernible distinction between the public interest standard for submerged lands activities that are within aquatic preserves as opposed to those occurring outside of the preserves.

The effect of the OFW designation on water quality parameters subject to a narrative standard (nutrients), and on water quality parameters that are not currently established by rule (e.g. emerging pathogens of concern) has not been established. In addition OFWs do not appear to enjoy any special consideration as designated uses subject to impaired waters restoration. The definitions of non-degradation and of ambient water quality for the purposes of OFW designation should be amended to ensure that they contemplate degradation by contaminants other than the current rule-based list of water quality standards and criteria. The extent to which BMPs for silviculture operations are sufficient to safeguard OFW water quality may require further research. In addition, the extent to which the OFW statute and rules recognize the ecological role and recreational value of riparian zones remains in question. This should be clarified by the FDEP. 


\section{Appendix A}

\section{Florida Administrative Law Cases Addressing OFW Rule}

\begin{tabular}{|c|c|c|c|c|c|}
\hline $\begin{array}{c}\text { Name, Case } \\
\text { Number, Date }\end{array}$ & Activity Permitted & OFW Involved & Legal Issues & Mitigation & $\begin{array}{l}\text { Holding: Recommended } \\
\text { Order and/or Final Order }\end{array}$ \\
\hline $\begin{array}{l}\text { Bay Oaks Circle } \\
\text { Association, Inc. } \\
\text { v. DEP and } \\
\text { Richard Perkins, } \\
\text { Case No. 99-0851 } \\
\underline{(1999)}\end{array}$ & $\begin{array}{l}\text { Environmental } \\
\text { Resource Permit (ERP) } \\
\text { to extend an existing } \\
\text { multi-family residential } \\
\text { docking facility that } \\
\text { would exceed } 500 \\
\text { square feet. Sovereign } \\
\text { submerged land lease to } \\
\text { permit the utilization of } \\
2,219 \text { square feet of } \\
\text { submerged bottomland. }\end{array}$ & $\begin{array}{l}\text { Lemon Bay- } \\
\text { Class II OFW, } \\
\text { aquatic preserve, } \\
\text { and state- } \\
\text { designated } \\
\text { "Special Water." }\end{array}$ & $\begin{array}{l}\text { Whether permitting criteria } \\
\text { set forth at } \S 373.414(1) \text {, Fla. } \\
\text { Stat. have been met. ( } 1 \text { 16). } \\
\text { The proposed extension } \\
\text { would have a negative } \\
\text { impact on sea grass and } \\
\text { navigation. }\end{array}$ & $\begin{array}{l}\text { No mitigation options discussed; } \\
\text { Petitioner simply proposed having } \\
\text { relevant statutes and rules waived } \\
\text { for his activity, without supporting } \\
\text { evidence. }\end{array}$ & $\begin{array}{l}\text { "The evidence fails to } \\
\text { establish that the proposed } \\
\text { extension of the dock is } \\
\text { clearly in the public } \\
\text { interest." ( } 933 \text { ). The ERP } \\
\text { and Land Lease denied. }\end{array}$ \\
\hline 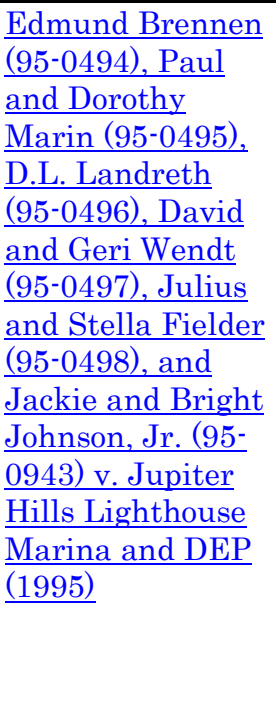 & $\begin{array}{l}\text { Dredge and Fill Permit } \\
\text { under r. } 62-312 \text {, Fla. } \\
\text { Admin. Code, to place } \\
\text { pilings and riprap in } \\
\text { state water for a } \\
\text { construction project to } \\
\text { enlarge an existing } \\
\text { marina and add new } \\
\text { slips for use by } \\
\text { sailboats. }\end{array}$ & $\begin{array}{l}\text { Jensen Beach to } \\
\text { Jupiter Inlet } \\
\text { Aquatic Preserve, } \\
\text { which is a part of } \\
\text { the Indian River } \\
\text { Preserve, a Class } \\
\text { III OFW. }\end{array}$ & $\begin{array}{l}\text { Whether Jupiter Hills } \\
\text { Lighthouse Marina is } \\
\text { entitled to a permit for its } \\
\text { project application submitted } \\
\text { July } 29,1992 \text {, and revised } \\
\text { November 15, 1993, to } \\
\text { enlarge an existing marina } \\
\text { and add new slips. }\end{array}$ & $\begin{array}{l}\text { Jupiter Hills has agreed to the } \\
\text { following mitigation activities: (a) } \\
\text { installation and maintenance of } \\
\text { an ex-filtration trench to improve } \\
\text { water quality by trapping grease } \\
\text { coming from the uplands and } \\
\text { intercepting up to three-fourths } \\
\text { of an inch of stormwater from } \\
\text { draining into the basin; (b) } \\
\text { prohibition of live-aboards, so as } \\
\text { to avoid fecal coliform violations; } \\
\text { (c) refrain from use of } \\
\text { construction materials treated by } \\
\text { heavy metals; (d) prohibition on } \\
\text { new powerboats docking at the } \\
\text { facility; (e) installation of } \\
\text { navigational and no wake signs, } \\
\text { for manatee protection; (f) and } \\
\text { the installation of riprap. }\end{array}$ & $\begin{array}{l}\text { Respondent Jupiter Hills } \\
\text { has provided reasonable } \\
\text { assurance that the proposed } \\
\text { project is clearly in the } \\
\text { public interest and will not } \\
\text { affect water quality } \\
\text { standards. ( } 15 \text { and } 41 \text { ). } \\
\text { Permit issued. "Respondent } \\
\text { Jupiter Hills has } \\
\text { demonstrated that it has } \\
\text { provided reasonable } \\
\text { assurance that the proposed } \\
\text { project will not cause water } \\
\text { quality violations." ( } ₫ 48) .\end{array}$ \\
\hline
\end{tabular}




\begin{tabular}{|c|c|c|c|c|c|}
\hline $\begin{array}{l}\text { Foster Burgess v. } \\
\text { DEP, Case no. 93- } \\
\underline{2900(1993)}\end{array}$ & $\begin{array}{l}\text { Dredge and Fill Permit } \\
\text { to construct a private } \\
\text { boat dock, a platform } \\
\text { for an "A" frame } \\
\text { camping shelter, and a } \\
\text { boardwalk all in } \\
\text { jurisdictional wetlands } \\
\text { along the water's edge } \\
\text { of a "small natural } \\
\text { basin off of the } \\
\text { Choctawhatchee River." }\end{array}$ & $\begin{array}{l}\text { Choctawhatchee } \\
\text { River - Class III } \\
\text { OFW. Adjacent to } \\
\text { Class II shellfish } \\
\text { waters. }\end{array}$ & $\begin{array}{l}\text { "Whether Petitioner's } \\
\text { application for a dredge and } \\
\text { fill permit provides } \\
\text { reasonable assurances that } \\
\text { compliance will be had with } \\
\text { applicable requirements of } \\
\text { Section } 403.918(2) \text {, Florida } \\
\text { Statutes; specifically, that } \\
\text { the project is in the public } \\
\text { interest and that existing } \\
\text { ambient water quality of an } \\
\text { Outstanding Florida Water } \\
\text { will not be lowered." ( } ₫ \\
\text { Statement of the Issues). }\end{array}$ & $\begin{array}{l}\text { No mitigation measures proposed } \\
\text { by Petitioner }\end{array}$ & $\begin{array}{l}\text { Petitioner failed to present } \\
\text { reasonable assurances that: } \\
\text { prohibited cumulative } \\
\text { impacts will not result } \\
\text { (subdivision of property and } \\
\text { proposal of numerous } \\
\text { similar projects); Class II } \\
\text { waters will not be degraded; } \\
\text { the project is clearly in the } \\
\text { public interest; ambient } \\
\text { water quality standards will } \\
\text { not be violated; and } \\
\text { detrimental secondary } \\
\text { impacts will not occur. } \\
\text { Permit denied. }\end{array}$ \\
\hline 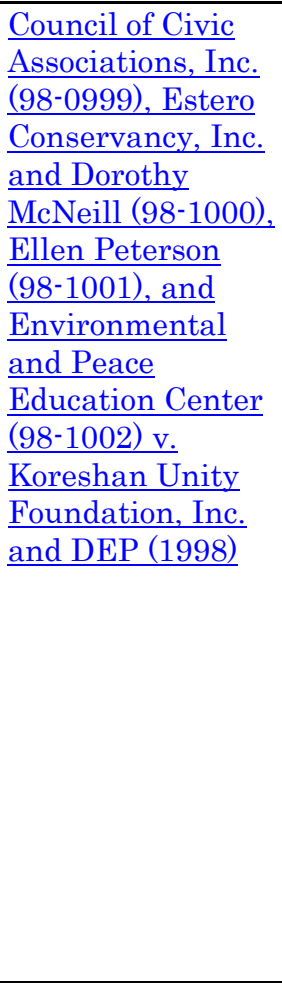 & $\begin{array}{l}\text { ERP for the } \\
\text { construction of a } \\
\text { wooden footbridge for } \\
\text { pedestrians over } \\
\text { Estero River and to } \\
\text { obtain a right to use } \\
\text { sovereign submerged } \\
\text { lands via easement }\end{array}$ & $\begin{array}{l}\text { Estero River- } \\
\text { Class III OFW }\end{array}$ & $\begin{array}{l}\text { Whether DEP should issue } \\
\text { permit and authorize the } \\
\text { use of sovereign submerged } \\
\text { lands when Koreshan has } \\
\text { not provided reasonable } \\
\text { assurance that the proposed } \\
\text { footbridge would not } \\
\text { adversely affect the water } \\
\text { quality of the Estero River. } \\
\text { The proposed footbridge } \\
\text { would adversely affect the } \\
\text { water quality in two } \\
\text { respects: turbidity caused } \\
\text { by the pilings and leaching } \\
\text { from the chromated copper } \\
\text { arsenate applied to the } \\
\text { pilings. The pilings to be } \\
\text { placed in the River } \\
\text { "effectively divide the river } \\
\text { into six segments of no } \\
\text { more than } 14 \text { feet each," } \\
\text { thereby adversely affecting } \\
\text { navigation and diminishing } \\
\text { the recreational value of the } \\
\text { River for canoeists and } \\
\text { kayakers. }\end{array}$ & $\begin{array}{l}\text { Koreshan proposed using } \\
\text { impermeable plastic or PVC } \\
\text { material to wrap the pilings on } \\
\text { the proposed footbridge to reduce } \\
\text { the leaching of deleterious } \\
\text { substances from the pilings. The } \\
\text { proposed permit requires that } \\
\text { Koreshan grant a conservation } \\
\text { easement for the entire } \\
\text { riverbank running along both } \\
\text { shorelines of Koreshan's two } \\
\text { parcels and also requires } \\
\text { Koreshan to plant leather fern or } \\
\text { other wetland species on three- } \\
\text { foot centers along along both } \\
\text { banks of the River for a distance } \\
\text { of } 30 \text { feet. }\end{array}$ & $\begin{array}{l}\text { Koreshan has failed to } \\
\text { provide reasonable } \\
\text { assurance that the } \\
\text { proposed footbridge will } \\
\text { not affect water quality } \\
\text { and is clearly in the public } \\
\text { interest. The ERP is } \\
\text { denied, and because of } \\
\text { concurrency requirements } \\
\text { of Sections } 253.77(2) \text { and } \\
\text { 373. 427(3), Florida } \\
\text { Statutes, the easement is } \\
\text { also denied. The proposed } \\
\text { footbridge would adversely } \\
\text { affect the public health, } \\
\text { safety, or welfare and the } \\
\text { property of others. }\end{array}$ \\
\hline
\end{tabular}




\begin{tabular}{|c|c|c|c|c|c|}
\hline $\begin{array}{l}\frac{\text { William and Jill }}{\text { Crouthers }(97-} \\
\text { 0994) and Paul } \\
\text { Tyre (97-1420) v. } \\
\text { Captain J.B.'s } \\
\text { Fish Camp and } \\
\text { DEP (1997) }\end{array}$ & $\begin{array}{l}\text { J.B Fish Camp (which } \\
\text { includes a restaurant } \\
\text { and aquaculture } \\
\text { facility) applied for an } \\
\text { ERP and variance } \\
\text { from provisions of } \\
\text { 40C-4.032(c), Fla. } \\
\text { Admin. Code, for } \\
\text { construction of a 16- } \\
\text { slip docking facility. }\end{array}$ & $\begin{array}{l}\text { Indian River } \\
\text { North - Class II } \\
\text { shellfish } \\
\text { harvesting OFW } \\
\text { and aquatic } \\
\text { preserve. }\end{array}$ & $\begin{array}{l}\text { J.B.'s wanted to replace its } \\
\text { two existing docks with } \\
\text { larger ones, as well as } \\
\text { construct a concrete boat- } \\
\text { launching ramp. They } \\
\text { requested a variance from r. } \\
\text { 40C-4.032(c), Fla. Admin. } \\
\text { Code. DEP issued the } \\
\text { permit and variance and } \\
\text { Petitioners objected due to } \\
\text { potential negative impacts } \\
\text { to water quality from boat } \\
\text { use and fish cleaning on the } \\
\text { boat docks and ramp. }\end{array}$ & $\begin{array}{l}\text { J.B.'s modified its original } \\
\text { proposed project, reducing it to } \\
\text { only one proposed dock, and no } \\
\text { boat ramp. The FDEP also placed } \\
\text { a number of conditions on the } \\
\text { variance including: requirement } \\
\text { of a wetland resource } \\
\text { management permit; turbidity } \\
\text { controls, if necessary; restricting } \\
\text { the maximum boats allowed to } \\
\text { dock at the facility; prohibiting } \\
\text { discharges into the water; } \\
\text { requiring that mooring areas be } \\
\text { deep enough to prevent prop } \\
\text { damage; requiring that any } \\
\text { structure allow maximum } \\
\text { sunlight penetration; and that } \\
\text { the boat ramp be permanently } \\
\text { closed. The FDEP also imposed } \\
\text { conditions designed to protect } \\
\text { manatees in the area. Finally, } \\
\text { JB's agreed to establish a } \\
\text { conservation easement over } 224 \\
\text { linear feet of the shoreline that } \\
\text { J.B.'s will plant with mangroves. }\end{array}$ & $\begin{array}{l}\text { Proposed activities will not } \\
\text { result in a worsening of } \\
\text { the impacts to water } \\
\text { quality. ( } ₫ \text { 40). Rather, it } \\
\text { should lessen them by } \\
\text { improving the depth at } \\
\text { which boats will dock } \\
\text { (reducing turbidity) and } \\
\text { through "the elimination of } \\
\text { fish cleaning on the docks, } \\
\text { the elimination of the } \\
\text { existing Bait Shop Dock, } \\
\text { and the elimination of the } \\
\text { existing boat ramp." ( } ₫ 40 \text { ). } \\
\text { Impacts may also be } \\
\text { lessened if J.B.'s adheres } \\
\text { to the conditions imposed } \\
\text { by FDEP on the docking of } \\
\text { boats at the proposed } \\
\text { Restaurant Dock. J.B.'s } \\
\text { has made reasonable } \\
\text { assurances to FDEP "that } \\
\text { the proposed project is } \\
\text { clearly in the public } \\
\text { interest." ( } 9 \text { 92). }\end{array}$ \\
\hline $\begin{array}{l}\text { Leland Egland v. } \\
\text { Largo Bayside, } \\
\text { Inc. and DEP, } \\
\underline{\text { Case no. } 88-3530} \\
\underline{(1998)}\end{array}$ & $\begin{array}{l}\text { Permit to alter } \\
\text { mangroves on } \\
\text { property owned by } \\
\text { Largo Bayside in Key } \\
\text { Largo }\end{array}$ & $\begin{array}{l}\text { Florida Bay, an } \\
\text { OFW. }\end{array}$ & $\begin{array}{l}\text { Largo Bayside owns a } \\
\text { condominium development } \\
\text { in Key Largo. Adjacent to } \\
\text { the units is a water body } \\
\text { bounded by a mangrove } \\
\text { berm approximately } 4 \text { acres } \\
\text { in size. Florida Bay is on } \\
\text { the other side of the berm. } \\
\text { The view of Florida Bay is, } \\
\text { to some extent, obstructed } \\
\text { by the mangroves. Largo } \\
\text { Bayside proposes to trim } \\
\text { the mangroves in the center } \\
\text { of the berm (about two } \\
\text { acres wide) to a height of } 13 \\
\text { feet above grade to improve } \\
\text { the view. }\end{array}$ & $\begin{array}{l}\text { Largo Bayside could have } \\
\text { trimmed a large amount of } \\
\text { mangroves according to an } \\
\text { exemption in r. 17-27.060, Fla. } \\
\text { Admin. Code. ( } ₫ \text { 5). However, } \\
\text { Largo Bayside agreed to certain } \\
\text { conditions by DEP to ensure no } \\
\text { environmental damage would } \\
\text { result from the trimming, as well } \\
\text { as to ensure no impact on water } \\
\text { quality or fish and wildlife would } \\
\text { occur. ( } ₫ \text { 4). Moreover, according } \\
\text { to the conditions, Largo Bayside } \\
\text { actually trimmed fewer } \\
\text { mangroves as a condition of this } \\
\text { permit. }\end{array}$ & $\begin{array}{l}\text { Largo Bayside provided } \\
\text { DEP with reasonable } \\
\text { assurance that no impacts } \\
\text { to water quality will occur } \\
\text { as a result of the proposed } \\
\text { trimming, and they have } \\
\text { shown that it is clearly in } \\
\text { the public interest. ( } ₫ 9) \text {. }\end{array}$ \\
\hline
\end{tabular}




\begin{tabular}{|c|c|c|c|c|c|}
\hline $\begin{array}{l}\text { Florida Audubon } \\
\text { Society, Inc., et } \\
\text { al. v. South } \\
\text { Florida Water } \\
\text { Management } \\
\text { District and } \\
\text { Lennar Homes, } \\
\text { Inc., Case no. 02- } \\
\text { 1629 (2002) }\end{array}$ & $\begin{array}{l}\text { ERP for development } \\
\text { of a } 516 \text {-acre } \\
\text { residential } \\
\text { community. }\end{array}$ & $\begin{array}{l}\text { The project is not } \\
\text { located in an OFW } \\
\text { nor would it result } \\
\text { in direct discharge } \\
\text { of surface wate } \\
\text { into an OFW. } \\
\text { However, it is } \\
\text { located about one } \\
\text { mile from the } \\
\text { southern part of } \\
\text { the Biscayne Bay, } \\
\text { an OFW, and } \\
\text { much of its central } \\
\text { and southern } \\
\text { parts, including } \\
\text { the area closest to } \\
\text { the Project site, } \\
\text { are within } \\
\text { Biscayne National } \\
\text { Park. }\end{array}$ & $\begin{array}{l}\text { Lennar Homes wanted an } \\
\text { ERP to build a 516-acre } \\
\text { residential community in } \\
\text { Miami-Dade County. The } \\
\text { application, as revised, was } \\
\text { for an ERP conceptually } \\
\text { approving the construction } \\
\text { of a surface water } \\
\text { management system to } \\
\text { serve the Project and } \\
\text { authorizing the } \\
\text { construction to clear the } \\
\text { site, excavate the wet } \\
\text { retention areas, and expand } \\
\text { an existing lake. }\end{array}$ & $\begin{array}{l}\text { The SFWMD imposed a flowage } \\
\text { easement on the property, } \\
\text { basically providing unlimited } \\
\text { maintenance discretion to the } \\
\text { SFWMD. Other conditions were } \\
\text { also imposed in relation to the } \\
\text { flowage easement. Lennar } \\
\text { Homes proposed mitigation to } \\
\text { offset the adverse impacts of the } \\
\text { project. }\end{array}$ & $\begin{array}{l}\text { "It was found that the } \\
\text { Project will not cause } \\
\text { adverse water quality } \\
\text { impacts to receiving } \\
\text { waters and adjacent } \\
\text { lands." ( } ₫ \text { 6). "The Flowage } \\
\text { Easement and new special } \\
\text { conditions do not impose } \\
\text { an inordinate burden upon } \\
\text { Lennar Homes." ( } ₫ \text { 37). } \\
\text { "The issuance of the ERP } \\
\text { without the Flowage } \\
\text { Easement and new special } \\
\text { conditions would } \\
\text { substantially impact the } \\
\text { ability of the District to } \\
\text { restore this part of } \\
\text { Biscayne Bay." ( } ₫ \text { 47). }\end{array}$ \\
\hline 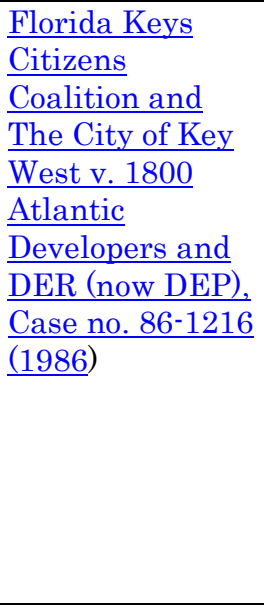 & $\begin{array}{l}\text { Fill permit and water } \\
\text { quality certification } \\
\text { for creation of a sand } \\
\text { beach, about 500' long } \\
\text { by } 100 \text { ' wide, requiring } \\
\text { placement of } 2,620 \\
\text { cubic yards of fill, } \\
2,200 \text { yards of which } \\
\text { would be waterward of } \\
\text { mean high water off } \\
\text { Key West, Florida. }\end{array}$ & $\begin{array}{l}\text { Project site waters } \\
\text { are "part of the } \\
\text { navigable open } \\
\text { waters of Hawk } \\
\text { Channel and the } \\
\text { Straits of Florida } \\
\text { (Atlantic Ocean)" - } \\
\text { Class III OFW. } \\
\text { The waters in the } \\
\text { area of the project } \\
\text { (within the } \\
\text { boundaries of the } \\
\text { Florida Keys } \\
\text { Special Waters) } \\
\text { were also an } \\
\text { OFW. }\end{array}$ & $\begin{array}{l}1800 \text { Atlantic was the } \\
\text { developer of a 168-unit } \\
\text { condominium property in } \\
\text { Key West and wanted to } \\
\text { build a beach. Petitioners } \\
\text { objected due to potential } \\
\text { negative impacts on fish, } \\
\text { wildlife, and the } \\
\text { environment. }\end{array}$ & $\begin{array}{l}1800 \text { Atlantic's original permit } \\
\text { application included proposed } \\
\text { construction of the beach, a jetty } \\
\text { on the east end of the beach, a } \\
\text { fishing pier on the west end of } \\
\text { the beach, and an art display } \\
\text { platform seaward. Due to DER's } \\
\text { concerns, they changed the } \\
\text { application and agreed to } \\
\text { conditions that may allow DER } \\
\text { to issue the ERP. }\end{array}$ & $\begin{array}{l}\text { It was ultimately found } \\
\text { that the project would } \\
\text { adversely impact fish and } \\
\text { wildlife habitat, marine } \\
\text { productivity, and } \\
\text { recreational values. } 1800 \\
\text { Atlantic did not meet its } \\
\text { burden of showing that the } \\
\text { project was clearly in the } \\
\text { public interest. The } \\
\text { hearing officer found that } \\
\text { the project, even as } \\
\text { amended, lacked the } \\
\text { requisite specificity needed } \\
\text { to provide reasonable } \\
\text { assurances. }\end{array}$ \\
\hline
\end{tabular}




\begin{tabular}{|c|c|c|c|c|c|}
\hline $\begin{array}{l}\text { Jeffery Jay } \\
\text { Frankel v. DEP, } \\
\text { Case no. 98-1326 } \\
\text { (1998) }\end{array}$ & $\begin{array}{l}\text { Petitioner seeks an } \\
\text { exemption from the } \\
\text { need to obtain an ERP } \\
\text { or alternatively an } \\
\text { ERP and a lease to } \\
\text { use state sovereign } \\
\text { submerged lands to } \\
\text { collect and sell } \\
\text { approximately } 600 \\
\text { pounds of live sand } \\
\text { per month. }\end{array}$ & $\begin{array}{l}\text { Florida Keys } \\
\text { National Marine } \\
\text { Sanctuary - Class } \\
\text { III OFW }\end{array}$ & $\begin{array}{l}\text { Petitioner collects and sells } \\
\text { "live sand," which is } \\
\text { considered a dredging } \\
\text { activity within a sanctuary. } \\
\text { "Live Sand is a calcium } \\
\text { carbonate sediment used in } \\
\text { public and home aquaria as } \\
\text { a decorative detoxifying } \\
\text { agent." ( } 9 \text { 3). "Live sand is } \\
\text { found on offshore water } \\
\text { bottoms in the Florida Keys } \\
\text { (where Petitioner engages } \\
\text { in his collection activities) } \\
\text { and other areas in Florida." } \\
\text { ( } \text { 4). Petitioner dives } \\
\text { underwater to scoop with } \\
\text { his hands and take away } \\
\text { the live sand, which has } \\
\text { significant environmental } \\
\text { effects. Removing the live } \\
\text { sand removes organisms } \\
\text { that are important } \\
\text { components to the aquatic } \\
\text { food chain, reduces the } \\
\text { biological diversity, leaves } \\
\text { the newly exposed } \\
\text { substrate unable to attract } \\
\text { the same significant benthic } \\
\text { community supported by } \\
\text { live sand, and increases } \\
\text { turbidity which affects the } \\
\text { water quality and clarity. }\end{array}$ & $\begin{array}{l}\text { Petitioner proposed no mitigation } \\
\text { options. "If the Department } \\
\text { authorizes the Project, it is } \\
\text { reasonable to anticipate that } \\
\text { other collectors of 'live sand' } \\
\text { would seek the Department's } \\
\text { approval to engage in similar } \\
\text { activity in the area" (cumulative } \\
\text { affects). ( } ₫ 26) \text {. }\end{array}$ & $\begin{array}{l}\text { "Petitioner has not } \\
\text { provided, through his } \\
\text { evidentiary presentation, } \\
\text { reasonable assurances } \\
\text { that the Project would not } \\
\text { result in violation of state } \\
\text { water quality standard or } \\
\text { that the Project would be } \\
\text { clearly in the public } \\
\text { interest." ( } ₫ 48) \text {. Further, } \\
\text { the project is inconsistent } \\
\text { with the goals and } \\
\text { objectives of the } \\
\text { Conceptual State Lands } \\
\text { Management Plan. ( } ₫ 23 \text { ). }\end{array}$ \\
\hline 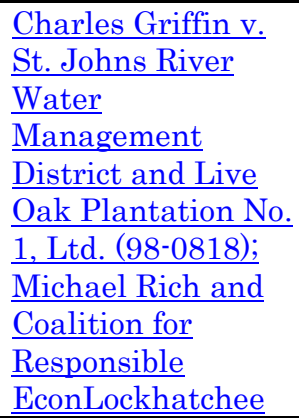 & $\begin{array}{l}\text { Application for a } \\
\text { conceptual approval of } \\
\text { an ERP for a multi- } \\
\text { phased single-family } \\
\text { project with two small } \\
\text { commercial sites on } \\
\text { approximately } 1,041 \\
\text { acres. }\end{array}$ & $\begin{array}{l}\text { Project site } \\
\text { located near } \\
\text { confluence the of } \\
\text { Econlockhatchee } \\
\text { (Econ) River and } \\
\text { Little } \\
\text { Econlockhatchee } \\
\text { River. The Live } \\
\text { Oak Reserve } \\
\text { property includes } \\
\text { approximately }\end{array}$ & $\begin{array}{l}\text { "Historically, the Live Oak } \\
\text { Reserve property has been } \\
\text { used for agricultural } \\
\text { practices, including } \\
\text { siliviculture and cattle } \\
\text { production. Some areas of } \\
\text { the property have been } \\
\text { logged and some areas have } \\
\text { been converted to pasture. } \\
\text { Cattle have grazed in } \\
\text { wetlands, thereby }\end{array}$ & $\begin{array}{l}\text { Petitioner developed a site plan } \\
\text { "which minimizes impacts to } \\
\text { wetlands and other surface water } \\
\text { functions, particularly as it } \\
\text { relates to the Econ river, and } \\
\text { maximizes the benefits to wildlife } \\
\text { by establishing a series of } \\
\text { wildfire corridors across the site." } \\
\text { ( } 114) \text {. Additionally, "the impacts } \\
\text { are mostly limited to the small } \\
\text { isolated wetlands, the }\end{array}$ & $\begin{array}{l}\text { "Live Oak submitted } \\
\text { detailed technical } \\
\text { information, including but } \\
\text { not limited to charts, } \\
\text { maps, calculations, } \\
\text { studies, analyses and } \\
\text { reports necessary to show } \\
\text { that the conceptual } \\
\text { development plan was } \\
\text { consistent with the } \\
\text { permitting criteria of the }\end{array}$ \\
\hline
\end{tabular}




\begin{tabular}{|c|c|c|c|c|c|}
\hline $\begin{array}{l}\text { Development, Inc. } \\
\text { v. St. Johns River } \\
\text { Water } \\
\text { Management } \\
\underline{\text { District and Live }} \\
\underline{\text { Oak Plantation No. }} \\
\underline{\underline{1, \text { Ltd. }(98-0819)}} \\
\underline{(1998)}\end{array}$ & & $\begin{array}{l}\text { half of Horseshoe } \\
\text { Lake, as well as } \\
\text { a small creek, } \\
\text { Brister Creek, } \\
\text { which flows from } \\
\text { Horseshoe Lake } \\
\text { across the } \\
\text { property to the } \\
\text { Econ River. Econ } \\
\text { River is a Class } \\
\text { III water and an } \\
\text { OFW. }\end{array}$ & $\begin{array}{l}\text { decreasing the amount and } \\
\text { diversity of groundcover } \\
\text { vegetation on portions of } \\
\text { the property. On-site } \\
\text { drainage ditches have had a } \\
\text { major impact on the } \\
\text { hydrological characteristics } \\
\text { of the wetlands on the } \\
\text { property, including the } \\
\text { reduction of surface water } \\
\text { elevations." ( } 9 \text { ). Live Oak } \\
\text { proposes to develop a large } \\
\text { multi-phased single-family } \\
\text { project with two small } \\
\text { commercial sites. The } \\
\text { project, to be known as Live } \\
\text { Oak Reserve, will be on } \\
\text { approximately } 1,041 \text { acres. } \\
\text { Petitioners allege negative } \\
\text { impacts to area wildlife. }\end{array}$ & $\begin{array}{l}\text { upland/wetland transitional } \\
\text { edges of the floodplain wetlands, } \\
\text { and portions ... already degraded } \\
\text { by a ranch roadway and ditch } \\
\text { placement. Live Oak focused its } \\
\text { impacts on areas, including } \\
\text { wetlands, that were historically } \\
\text { disturbed." ( } ₫ \text { 63). "The proposed } \\
\text { on-site component of the } \\
\text { mitigation plan entails the } \\
\text { preservation of } 19.3 \text { acres of } \\
\text { herbaceous marsh, } 373.2 \text { acres of } \\
\text { forested wetlands, and } 124.9 \\
\text { acres of uplands. The mitigation } \\
\text { plan preserves approximately } \\
\text { 5.65 acres of isolated wetlands } \\
\text { on-site, and approximately } \\
\text { 386.86 acres of [other] wetlands } \\
\text { on-site." ( } ₫ \text { 68). "The off-site } \\
\text { component of the mitigation plan } \\
\text { is the contribution of } \$ 160,525 \\
\text { towards participation in the } \\
\text { SJRWMD acquisition of a } \\
\text { conservation easement over the } \\
3,456 \text { acre Yarborough parcel. } \\
\text { The Yarborough parcel is located } \\
\text { in the northeastern corner of the } \\
\text { Econ River Hydrologic Basin. } \\
\text { The Yarborough parcel } \\
\text { encompasses property north and } \\
\text { south of the Econ River." ( } ₫ 79 \text { ). }\end{array}$ & $\begin{array}{l}\text { SJRWMD found in } \\
\text { Chapter } 40 \mathrm{C}-4 \text {, Florida } \\
\text { Administrative Code." ( } \mathbb{} \\
\text { 12). "The evidence } \\
\text { presented at the final } \\
\text { hearing demonstrated that } \\
\text { Live Oak has provided } \\
\text { reasonable assurance that } \\
\text { the requirements of } \\
\text { SJRWMD rules have been } \\
\text { met and the permit should } \\
\text { be granted." ( } 119 \text { ). Live } \\
\text { Oak will have no adverse } \\
\text { effects on the health, } \\
\text { safety, or property of } \\
\text { others and any adverse } \\
\text { impacts will be adequately } \\
\text { offset by mitigation. Live } \\
\text { Oak is not contrary to the } \\
\text { public interest. Therefore, } \\
\text { the ERP approval was } \\
\text { upheld. }\end{array}$ \\
\hline $\begin{array}{l}\text { Michael } \\
\text { Guttman v. } \\
\text { FDEP and ADR } \\
\text { of Pensacola, } \\
\text { Case no. 00-2524 } \\
\underline{(2000)}\end{array}$ & $\begin{array}{l}\text { Wetland resource } \\
\text { permit and sovereign } \\
\text { submerged lands } \\
\text { authorization allowing } \\
\text { the construction of a } \\
\text { 30-slip docking facility } \\
\text { on Big Lagoon, } \\
\text { Escambia County, } \\
\text { Florida. }\end{array}$ & $\begin{array}{l}\text { Big Lagoon - } \\
\text { Class III water } \\
\text { and OFW. }\end{array}$ & $\begin{array}{l}\text { Petitioner opposes the } \\
\text { issuance of a WRP since he } \\
\text { lives less than } 1 \text { mile from } \\
\text { the proposed project, which } \\
\text { is part of a condominium } \\
\text { property to be constructed } \\
\text { on the upland portion of the } \\
\text { property. Reasons for } \\
\text { Petitioner's opposition } \\
\text { include the status of the } \\
\text { water as an OFW and } \\
\text { added navigational hazards }\end{array}$ & $\begin{array}{l}\text { The negative impacts were } \\
\text { secondary in nature, meaning the } \\
\text { facility itself (the dock, platform, } \\
\text { and pilings) would not cause the } \\
\text { negative impacts. Rather, the } \\
\text { real negative impacts were the } \\
\text { secondary impacts associated } \\
\text { with increased boat traffic that } \\
\text { would likely cause more } \\
\text { turbidity. The applicant proposed } \\
\text { placing pilings with signage } \\
\text { reading "NO BOATS BEYOND }\end{array}$ & $\begin{array}{l}\text { Originally, there were } \\
\text { three positive, one neutral, } \\
\text { and four negative benefits } \\
\text { or impacts associated with } \\
\text { the project. In the ALJ's } \\
\text { judgment, the negative } \\
\text { impacts, which were } \\
\text { secondary in nature, } \\
\text { outweighed any positive } \\
\text { benefits and the project } \\
\text { was contrary to the public } \\
\text { interest and was not }\end{array}$ \\
\hline
\end{tabular}




\begin{tabular}{|c|c|c|c|c|c|}
\hline & & & $\begin{array}{l}\text { from the project. Originally, } \\
\text { the project was denied } \\
\text { because of adverse affects of } \\
\text { fish and their habitat } \\
\text { because of a further } \\
\text { thinning of seagrass colony } \\
\text { and increased water } \\
\text { turbidity. }\end{array}$ & $\begin{array}{l}\text { THIS POINT" to deter boats from } \\
\text { navigating across the seagrass. } \\
\text { Similar pilings and signage have } \\
\text { been successful on the North } \\
\text { shore of Big Lagoon. ( } 9 \text { 8). To } \\
\text { mitigate the turbidity caused by } \\
\text { wave action from the boats, the } \\
\text { applicant proposes placing an } \\
\text { aluminum baffle system along } \\
\text { the outermost slips (waterward } \\
\text { side) of the facility to disperse } \\
\text { wave action. Once the baffle } \\
\text { system is installed, it will become } \\
\text { colonized with sessils (barnacles } \\
\text { and oysters), which should } \\
\text { provide new habitat for fish in } \\
\text { the area. }\end{array}$ & $\begin{array}{l}\text { permitted. However, on } \\
\text { remand the applicant was } \\
\text { given an opportunity to } \\
\text { propose mitigation } \\
\text { measures to offset the } \\
\text { negative impacts. These } \\
\text { were accepted by DEP and } \\
\text { the permit was ultimately } \\
\text { approved. }\end{array}$ \\
\hline $\begin{array}{l}\text { Hernstadt } \\
\text { Broadcasting } \\
\text { Corporation v. } \\
\text { DER and The } \\
\text { Charter Club, } \\
\text { Inc., Case no. 80- } \\
\text { 1702 (1981) }\end{array}$ & $\begin{array}{l}\text { ERPs for building a } \\
\text { radio transmitter } \\
\text { tower and access dock } \\
\text { in state owned } \\
\text { submerged lands in } \\
\text { Biscayne Bay. }\end{array}$ & $\begin{array}{l}\text { Biscayne Bay, a } \\
\text { State Aquatic } \\
\text { Preserve and } \\
\text { OFW. }\end{array}$ & $\begin{array}{l}\text { Petitioner applied for ERPs } \\
\text { to construct a radio } \\
\text { transmitter tower and } \\
\text { access dock in state } \\
\text { submerged land within the } \\
\text { Biscayne Bay. "The } \\
\text { placement of the pilings } \\
\text { would cause the destruction } \\
\text { of certain seagrasses in that } \\
\text { area, while at the same } \\
\text { time promoting the } \\
\text { introduction of marine life } \\
\text { along the surfaces of the } \\
\text { tower and dock supports. } \\
\text { Seagrasses in the area } \\
\text { where the grounding } \\
\text { system would be placed } \\
\text { may be destroyed and } \\
\text { although the copper to be } \\
\text { used would be nickel plated, } \\
\text { thereby inhibiting the } \\
\text { release of the toxic } \\
\text { properties of the coated } \\
\text { copper, eventually the } \\
\text { nickel plating would break } \\
\text { down and the marine life }\end{array}$ & $\begin{array}{l}\text { Petitioner intends to place } \\
\text { channel markers to divert boat } \\
\text { traffic away from the tower to aid } \\
\text { in navigation. Petitioner } \\
\text { contends its public service } \\
\text { function through programs it } \\
\text { broadcasts and its emergency } \\
\text { capabilities and the ancillary } \\
\text { opportunities to be offered to } \\
\text { governmental bodies to use the } \\
\text { transmitter tower as a } \\
\text { communication link. }\end{array}$ & $\begin{array}{l}\text { "Petitioner has failed to } \\
\text { affirmatively demonstrate } \\
\text { that this project is clearly } \\
\text { in the public interest. The } \\
\text { project is not in keeping } \\
\text { with the provisions of the } \\
\text { Biscayne Bay Aquatic } \\
\text { Preserve Act and although } \\
\text { it would insure to the } \\
\text { benefit of certain } \\
\text { governmental agencies (i.e. } \\
\text { the City of Miami) it is } \\
\text { incompatible with the } \\
\text { efforts of Dade County } \\
\text { through its Comprehensive } \\
\text { Master Plan, its Biscayne } \\
\text { Bay Management Plan } \\
\text { and the Biscayne Bay } \\
\text { Restoration Plan which is } \\
\text { administered by the DER. } \\
\text { The Biscayne Bay Act and } \\
\text { the various plans call for } \\
\text { the availability of this area } \\
\text { of Biscayne Bay for } \\
\text { purposes of recreation in a } \\
\text { way which protects the }\end{array}$ \\
\hline
\end{tabular}




\begin{tabular}{|c|c|c|c|c|c|}
\hline & & & $\begin{array}{l}\text { communities adjacent to the } \\
\text { mesh would be harmed by } \\
\text { the copper. The loss of } \\
\text { seagrasses under the grid } \\
\text { could cause a reduction in } \\
\text { fish population.” ( } ₫ 16) \text {. } \\
\text { Moreover, the installation } \\
\text { of the radio tower and } \\
\text { access dock in the Biscayne } \\
\text { Bay is an impediment to } \\
\text { navigation. ( } ₫ 17) \text {. }\end{array}$ & & $\begin{array}{l}\text { environment and } \\
\text { emphasizes aesthetics." ( } \\
\text { 33). "The project is an } \\
\text { unreasonable interference } \\
\text { with the lawful and } \\
\text { traditional public uses } \\
\text { contemplated for the } \\
\text { preserve which would } \\
\text { include fishing, boating } \\
\text { and swimming, both in } \\
\text { terms of the area that now } \\
\text { exists and the area as it is } \\
\text { contemplated to be } \\
\text { developed in the future." } \\
\text { (ף 29). }\end{array}$ \\
\hline $\begin{array}{l}\text { Ralph Jensen v. } \\
\text { DER, Case no. 89- } \\
\underline{2064(1989)}\end{array}$ & $\begin{array}{l}\text { Permit to fill } \\
\text { submerged areas } \\
\text { waterward of the } \\
\text { mean high water line } \\
\text { abutting property } \\
\text { owned by Petitioner } \\
\text { on Big Pine Key. } \\
\text { Petitioner also } \\
\text { proposed to place a } \\
\text { riprap revetment over } \\
\text { seagrass in the } \\
\text { submerged area, and } \\
\text { pilings for a stilted } \\
\text { structure in the } \\
\text { submerged areas. }\end{array}$ & $\begin{array}{l}\text { Florida Keys - } \\
\text { Class III Special } \\
\text { Waters OFW }\end{array}$ & $\begin{array}{l}\text { The proposed project site is } \\
\text { very diverse and } \\
\text { productive. The filling of } \\
\text { this area would result in } \\
\text { the direct elimination of } \\
\text { healthy seagrass beds, a } \\
\text { drop in the diversity of } \\
\text { organisms existing in the } \\
\text { filled area, and violate } \\
\text { standards of turbidity. } \\
\text { "Petitioner contends he's } \\
\text { trying to reclaim a portion } \\
\text { of his lot which has eroded, } \\
\text { however the evidence of } \\
\text { erosion was very slight and } \\
\text { only found in a small area } \\
\text { where the property adjoins } \\
\text { the vertical seawall of the } \\
\text { adjacent property." ( } 5 \text { 5). } \\
\text { Respondent claims valuable } \\
\text { and diverse wildlife and } \\
\text { habitat in the proposed } \\
\text { activity area will be } \\
\text { adversely affected. }\end{array}$ & $\begin{array}{l}\text { "The filling proposal does not } \\
\text { include any measures designed to } \\
\text { mitigate for or offset these } \\
\text { expected adverse impacts." }\end{array}$ & 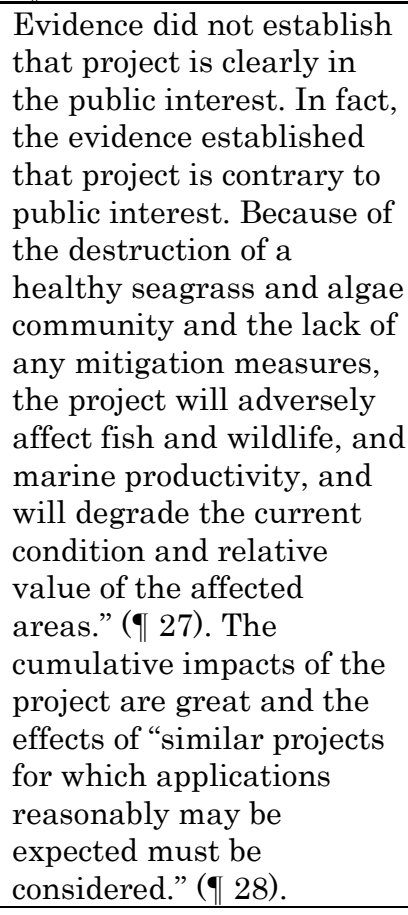 \\
\hline
\end{tabular}




\begin{tabular}{|c|c|c|c|c|c|}
\hline $\begin{array}{l}\text { Manasota-88, Inc. } \\
\text { and Manatee } \\
\text { County Save Our } \\
\text { Bays Association, } \\
\text { Inc., Martin } \\
\text { Rosen, and Faye } \\
\text { Rosen v. Hunt } \\
\text { Building } \\
\text { Corporation and } \\
\text { DER, Case nos. } \\
\underline{90-2350 \text { and } 90^{-}} \\
2736(1990)\end{array}$ & $\begin{array}{l}\text { Dredge and fill permit } \\
\text { for construction of a } \\
3,800 \text { square foot dock } \\
\text { and relocation of an } \\
\text { existing access } \\
\text { channel. }\end{array}$ & $\begin{array}{l}\text { Property located } \\
\text { contiguous to } \\
\text { Sarasota Bay, a } \\
\text { Class II water } \\
\text { body and OFW. }\end{array}$ & $\begin{array}{l}\text { Whether Hunt Building } \\
\text { Corporation should be } \\
\text { issued a permit to construct } \\
\text { a linear dock along an } \\
\text { artificial canal running into } \\
\text { Sarasota Bay, and to } \\
\text { relocate an existing access } \\
\text { channel by dredging a } \\
\text { replacement channel to the } \\
\text { canal. DER identified } \\
\text { several deficiencies in the } \\
\text { proposal which it required } \\
\text { be modified before a permit } \\
\text { could be issued. Hunt } \\
\text { agreed to comply with all of } \\
\text { the Department's modifying } \\
\text { requirements. }\end{array}$ & $\begin{array}{l}\text { "Any sea grasses in the area of } \\
\text { the channel will be protected by } \\
\text { the installation of signs } \\
\text { indicating their location. Speed } \\
\text { will be limited by the installation } \\
\text { of "No Wake" zone signs, and, in } \\
\text { addition, the natural dog-leg in } \\
\text { the channel should minimize the } \\
\text { impact to adjacent shorelines and } \\
\text { reduce the potential for shoaling } \\
\text { or erosion." ( } 9 \text { ). Plan calls for } \\
\text { the removal of approx. } 20 \text { trees } \\
\text { and the trimming of an } \\
\text { additional } 230 \text {. Because the } \\
\text { trimming, as a part of an exempt } \\
\text { activity, is also exempt, } \\
\text { mitigation in not required. Hunt, } \\
\text { however, proposed to plant } 3 \\
\text { trees for every tree removed or } \\
\text { trimmed. This proposal was } \\
\text { considered acceptable to the } \\
\text { Department and was } \\
\text { incorporated as one of the permit } \\
\text { conditions. As a result of the } \\
\text { mitigation activities, mangrove } \\
\text { and seagrass populations should } \\
\text { be increased and the shoreline } \\
\text { enhanced. In regards to turbidity } \\
\text { and water quality, to insure that } \\
\text { existing ambient water quality } \\
\text { standards are maintained during } \\
\text { construction, the Department } \\
\text { has established a mixing zone } \\
\text { and will require the use of double } \\
\text { turbidity curtains. To protect the } \\
\text { manatee population, "the } \\
\text { Department has also included } \\
\text { conditions to the permit } \\
\text { requiring the posting of manatee } \\
\text { awareness signs along the canal } \\
\text { and channel and the installation } \\
\text { of a permanent informational } \\
\text { display at the facility." ( } 14 \text { ). }\end{array}$ & $\begin{array}{l}\text { ALJ found the project to be } \\
\text { clearly in the public } \\
\text { interest. There is no } \\
\text { indication that significant } \\
\text { historical and } \\
\text { archeological resources } \\
\text { will be substantially } \\
\text { affected. In fact, none were } \\
\text { shown to exist. The area is } \\
\text { currently a mangrove } \\
\text { swamp performing no } \\
\text { function other than that of } \\
\text { a step in the ecological } \\
\text { water purification system. } \\
\text { Evidence of record shows } \\
\text { that this function, now } \\
\text { only minimally effective, } \\
\text { will be enhanced and } \\
\text { improved by the project. } \\
\text { As to the possible effect on } \\
\text { the public health, safety, } \\
\text { welfare, or the property of } \\
\text { others, notwithstanding } \\
\text { considerable cross } \\
\text { examination of the } \\
\text { applicant's and } \\
\text { Department's witnesses, } \\
\text { the Petitioners were } \\
\text { unable to show any } \\
\text { appreciable detriment to } \\
\text { any." ( } ₫ \text { 25). "Since any } \\
\text { discharge of pollutants } \\
\text { into Sarasota Bay, an } \\
\text { OFW, would be minimal, } \\
\text { non-detectable and non- } \\
\text { measurable, such } \\
\text { pollutants as would exist } \\
\text { are permissible under the } \\
\text { water quality standards." } \\
\text { ( } ₫ 27 \text { ). }\end{array}$ \\
\hline
\end{tabular}




\begin{tabular}{|c|c|c|c|c|c|}
\hline $\begin{array}{l}\text { Ocean Reef Club, } \\
\text { Inc. v. DER, Case } \\
\text { no. 87-4660 (1988) } \\
\end{array}$ & $\begin{array}{l}\text { Dredge and fill permit } \\
\text { authorizing } \\
\text { excavation of a marina } \\
\text { basin, the connection } \\
\text { through mangroves of } \\
\text { that basin to an } \\
\text { existing tidal creek, } \\
\text { and the use of such } \\
\text { creek for navigational } \\
\text { access. }\end{array}$ & $\begin{array}{l}\text { Key Largo-- } \\
\text { Class III Special } \\
\text { Waters OFW. } \\
\text { "The wetlands in } \\
\text { and around the } \\
\text { project site, } \\
\text { including No } \\
\text { Name Creek, are } \\
\text { within an OFW, } \\
\text { specifically the } \\
\text { Florida Keys } \\
\text { Special Waters. } \\
\text { The project } \\
\text { site is located in } \\
\text { North Key Largo." } \\
\text { ( } ₫ 17 \text { ). }\end{array}$ & $\begin{array}{l}\text { Petitioner was issued a } \\
\text { permit to construct } \\
\text { residential docking spaces } \\
\text { in Key Largo. "During the } 2 \\
\text { year processing time } \\
\text { leading to issuance of the } \\
\text { permit, Petitioner sold a } \\
\text { portion of their property } \\
\text { including the access } \\
\text { channel to third parties } \\
\text { that then refused channel } \\
\text { construction across their } \\
\text { property." ( } ₫ \text { 5). Petitioners } \\
\text { requested modifications to } \\
\text { their permit. Respondent } \\
\text { claims this project is so } \\
\text { different that it requires a } \\
\text { new permit application. ( } ₫ \\
\text { 6). "DER's consistently } \\
\text { applied policy is to require } \\
\text { all such significant permit } \\
\text { modifications to be } \\
\text { processed de novo as wholly } \\
\text { new permit applications } \\
\text { because to do otherwise } \\
\text { would not be in the public } \\
\text { interest." ( } ₫ \text { 6). }\end{array}$ & $\begin{array}{l}\text { "It is implausible that } \\
\text { Petitioner's plans to limit boat } \\
\text { size through condominium } \\
\text { documents to be enforced } \\
\text { through a homeowners } \\
\text { association, to install mirrors, } \\
\text { signaling devices, and latches at } \\
\text { certain points along the creek, } \\
\text { and to install tide staffs at creek } \\
\text { entrances will prevent potential } \\
\text { head-on boat collisions or } \\
\text { bottlenecks in No Name Creek. It } \\
\text { is equally implausible that these } \\
\text { procedures can provide } \\
\text { reasonable assurances that there } \\
\text { will not be a chronic increase in } \\
\text { water turbidity from increased } \\
\text { use or damage to biota from } \\
\text { propellers and boat impact." ( } \\
\text { 19). }\end{array}$ & $\begin{array}{l}\text { Ocean Reef Club has not } \\
\text { provided reasonable } \\
\text { assurance that this project } \\
\text { will be clearly in the public } \\
\text { interest or that water } \\
\text { quality standards will not } \\
\text { be violated. ( } ₫ 32 \text { and 35). } \\
\text { "The increased boat use of } \\
\text { No Name Creek inherent } \\
\text { in this dredging project } \\
\text { will adversely affect the } \\
\text { quality and diversity of the } \\
\text { biota," which currently } \\
\text { enjoys a strong ecological } \\
\text { status. ( } 9 \text { 21). This } \\
\text { project will adversely } \\
\text { affect fishing and } \\
\text { recreational values as well } \\
\text { as marine productivity in } \\
\text { the creek, even while there } \\
\text { is some increase in } \\
\text { recreational and fishing } \\
\text { values for marina } \\
\text { residents." ( } ₫ 41 \text { ). "The } \\
\text { current condition and } \\
\text { relative value of functions } \\
\text { being performed by the } \\
\text { creek are extremely high } \\
\text { and the factors proposed in } \\
\text { mitigation will not } \\
\text { ensure recolonization of } \\
\text { the same high quality and } \\
\text { diverse biota." ( } ₫ 43 \text { ). } \\
\text { Permit denied. }\end{array}$ \\
\hline $\begin{array}{l}\text { Pine Island } \\
\text { Properties, Ltd. v. } \\
\text { FDEP, Case no. } \\
\underline{93-2713(1994)}\end{array}$ & $\begin{array}{l}\text { Permit to fill } 0.78 \\
\text { acres of wetlands for } \\
\text { residential } \\
\text { construction. }\end{array}$ & $\begin{array}{l}\text { Project site } \\
\text { immediately } \\
\text { adjacent to Forty } \\
\text { Acre Bay/Bay } 36, \\
\text { a Class II OFW } \\
\text { (part of the Pine } \\
\text { Island Sound } \\
\text { Aquatic Preserve). }\end{array}$ & $\begin{array}{l}\text { FDEP initially denied } \\
\text { Petitioner's permit request, } \\
\text { over concerns about the } \\
\text { potential for turbidity- } \\
\text { related water quality } \\
\text { violations due to increased } \\
\text { boat use, the adverse } \\
\text { floristic impact caused by } \\
\text { fill washout into adjacent }\end{array}$ & $\begin{array}{l}\text { Petitioner presented mitigation } \\
\text { options, but FDEP was still not } \\
\text { reasonably assured that the } \\
\text { project's impacts would be offset. }\end{array}$ & $\begin{array}{l}\text { "The evidence establishes } \\
\text { that because this project } \\
\text { will adversely affect the } \\
\text { conservation and habitat } \\
\text { of fish and wildlife, } \\
\text { including endangered or } \\
\text { threatened species, will } \\
\text { cause harmful erosion of } \\
\text { the shallow bay bottom, }\end{array}$ \\
\hline
\end{tabular}




\begin{tabular}{|c|c|c|c|c|c|}
\hline & & & $\begin{array}{l}\text { wetlands, the loss of the } \\
\text { filtering benefits provided } \\
\text { via the filled wetlands and } \\
\text { the adverse impact on } \\
\text { wildlife habitat. ( } ₫ 22 \text { ). }\end{array}$ & & $\begin{array}{l}\text { will adversely affect the } \\
\text { fishing or recreational } \\
\text { values or marine } \\
\text { productivity in the vicinity } \\
\text { of the project, and will } \\
\text { cause a permanent } \\
\text { adverse impact on the } \\
\text { current condition and } \\
\text { relative value of functions } \\
\text { being performed by areas } \\
\text { affected by the proposed } \\
\text { activity, the proposed } \\
\text { permit is contrary to } \\
\text { public interest” and will } \\
\text { result in an adverse } \\
\text { impact to and degradation } \\
\text { of an OFW. ( } 97 \text {. The } \\
\text { evidence establishes that } \\
\text { adverse secondary and } \\
\text { cumulative impacts will } \\
\text { result from permitting this } \\
\text { project. Permit denied. }\end{array}$ \\
\hline $\begin{array}{l}\text { Sarasota County } \\
\text { and Midnight } \\
\text { Pass Society, Inc. } \\
\text { v. DER, Case no. } \\
90-3533(1990)\end{array}$ & $\begin{array}{l}\text { Permit to dredge two } \\
\text { access channels and a } \\
\text { deposition basin along } \\
\text { Bird Island to connect } \\
\text { the inlet to the } \\
\text { Intracoastal } \\
\text { Waterway. } \\
\text { Approximately } \\
283,000 \text { cubic yards of } \\
\text { material would be } \\
\text { dredged. Some of the } \\
\text { dredged materials } \\
\text { were to be deposited } \\
\text { along the nearby } \\
\text { beaches of Siesta Key } \\
\text { and Casey Key. The } \\
\text { County owns a stretch } \\
\text { of beach and uplands } \\
\text { along the areas to be } \\
\text { dredged. }\end{array}$ & $\begin{array}{l}\text { Little Sarasota } \\
\text { Bay - Class III } \\
\text { OFW. "The project } \\
\text { site is located at } \\
\text { the juncture of } \\
\text { Siesta Key and } \\
\text { Casey Key. These } \\
\text { Keys form a } \\
\text { barrier along the } \\
\text { western boundary } \\
\text { of Little Sarasota } \\
\text { Bay." ( }(3) \text {. }\end{array}$ & $\begin{array}{l}\text { The County's original plan } \\
\text { for the reopening of an inlet } \\
\text { that emptied into the Gulf } \\
\text { of Mexico was denied by } \\
\text { DER. The central issue in } \\
\text { this case is whether the } \\
\text { DER should grant a permit } \\
\text { requested by Sarasota } \\
\text { County. This request was } \\
\text { supported by the } \\
\text { Intervenor, Midnight Pass } \\
\text { Society, Inc. and opposed by } \\
\text { the Intervenors, Manasota- } \\
\text { 88, Inc., North Casey Key } \\
\text { Association, Sierra Club, } \\
\text { Inc., and Jeffrey Jones. }\end{array}$ & $\begin{array}{l}\text { Since the area in discussion is } \\
\text { critical habitat for the West } \\
\text { Indian Manatee, the County } \\
\text { proposed a manatee protection } \\
\text { program. ( } ₫ 22-23 \text { ). They also } \\
\text { proposed a turtle protection } \\
\text { program to combat impacts to the } \\
\text { Loggerhead Sea Turtle's nesting } \\
\text { habitat. ( } ₫ 27) \text {. If the channels } \\
\text { are constructed, "the flushing } \\
\text { and arrival of predator fishes will } \\
\text { adversely affect the nursery } \\
\text { habitat." ( } ₫ 32 \text { ). "The dredging } \\
\text { proposed by the County would } \\
\text { eliminate at least } 50 \text { acres of } \\
\text { wetlands. At least ten acres of } \\
\text { seagrasses to be dredged would } \\
\text { not be expected to reseed or } \\
\text { colonize in the deep channel cuts" } \\
\text { and mitigation for loss of dredged } \\
\text { seagrasses has not been proposed }\end{array}$ & $\begin{array}{l}\text { The County failed to } \\
\text { establish that the proposed } \\
\text { project is clearly in the } \\
\text { public interest. ( } ₫ 43 \text { ). } \\
\text { "Based upon the criteria } \\
\text { cited above, the County } \\
\text { has not demonstrated that } \\
\text { any of the positive } \\
\text { consequences expected to } \\
\text { flow from this project } \\
\text { would balance or outweigh } \\
\text { the negative impacts } \\
\text { which are reasonably } \\
\text { expected. Advantages to } \\
\text { boaters or recreational } \\
\text { users of the pass do not } \\
\text { adequately offset the } \\
\text { impacts to the manatee, } \\
\text { the estuarine fisheries, the } \\
\text { seagrasses, the mangroves, } \\
\text { the turtles, and the birds }\end{array}$ \\
\hline
\end{tabular}




\begin{tabular}{|c|c|c|c|c|c|}
\hline & & & & $\begin{array}{l}\text { by the County while mitigation } \\
\text { for lost mangroves was proposed. } \\
\text { ( } 34 \text { ). In order to complete both } \\
\text { access channels it is expected } \\
\text { that } 43.8 \text { acres of wetlands will } \\
\text { be affected by the dredging. } \\
\text { Additionally, "the proposed } \\
\text { project will require beach } \\
\text { renourishment to continue for an } \\
\text { indefinite period of time." ( } ₫ \text { 37). } \\
\text { Marine environments do not } \\
\text { serve a more useful } \\
\text { environmental purpose than } \\
\text { estuarine systems. The water } \\
\text { quality within LSB will not be } \\
\text { significantly improved as a result } \\
\text { of the reopening of the inlet. "The } \\
\text { Department has not permitted } \\
\text { the destruction of a habitat of } \\
\text { this size without requiring the } \\
\text { applicant to provide extensive } \\
\text { mitigation." ( } ₫ \text { 40). }\end{array}$ & $\begin{array}{l}\text { which are currently } \\
\text { utilizing this estuarine } \\
\text { environment." (đ 49). }\end{array}$ \\
\hline $\begin{array}{l}\text { James Slater et } \\
\text { al.v. Orange } \\
\text { County and South } \\
\text { Florida Water } \\
\text { Management } \\
\text { District, Case no. } \\
97-0437 \text { (1998) }\end{array}$ & $\begin{array}{l}\text { An ERP for a park and } \\
\text { boat ramp project. }\end{array}$ & $\begin{array}{l}\text { Lake Isleworth - } \\
\text { Class III OFW, } \\
\text { part of the Butler } \\
\text { Chain of Lakes, a } \\
\text { series of } \\
\text { interconnected } \\
\text { lakes in Orange } \\
\text { county, covering } \\
\text { in excess of 5,000 } \\
\text { acres. }\end{array}$ & $\begin{array}{l}\text { Whether Orange County } \\
\text { should be granted an ERP } \\
\text { to expand access to the } \\
\text { Lake by the addition of } \\
\text { another boat park and } \\
\text { ramp in the vicinity of the } \\
\text { petitioners and intervenor's } \\
\text { (Regina Gibbs) properties. }\end{array}$ & $\begin{array}{l}\text { "The project is expected to result } \\
\text { in } 0.07 \text { acres of secondary } \\
\text { wetland impacts (removal of } \\
\text { littoral zone vegetation) above } \\
\text { that required for construction. ( } \\
56) \text {. "A total of } 0.14 \text { acres of } \\
\text { wetland impacts will occur from } \\
\text { direct construction and } \\
\text { secondary wetland impacts." ( } \\
57) \text {."Mitigation for the } 0.14 \text { acres } \\
\text { of wetland impact includes } 0.56 \\
\text { acres of wetland creation." ( } ₫ 58 \text { ). }\end{array}$ & $\begin{array}{l}\text { Orange County provided } \\
\text { reasonable assurances } \\
\text { that the construction and } \\
\text { operation of the proposed } \\
\text { boat ramp will comply } \\
\text { with all applicable water } \\
\text { quality, water quantity, } \\
\text { and environmental } \\
\text { permitting criteria, will } \\
\text { not cause adverse water } \\
\text { resource impacts, will not } \\
\text { cause violations of } \\
\text { applicable state water } \\
\text { quality standards, and is } \\
\text { clearly in the public } \\
\text { interest. }\end{array}$ \\
\hline
\end{tabular}




\begin{tabular}{|c|c|c|c|c|c|}
\hline $\begin{array}{l}\text { Sunset Acres } \\
\text { Property Owners } \\
\text { Association v. } \\
\text { DEP, Case no. 91- } \\
\underline{7958(1996)}\end{array}$ & $\begin{array}{l}\text { Permit for the removal } \\
\text { of a plug that, prior to } \\
\text { a1991 storm, had } \\
\text { separated the Sunset } \\
\text { Acres channel and } \\
\text { canal system from } \\
\text { Florida Bay. ( } ₫ \text { 67). } \\
\text { The project also } \\
\text { includes the shoaling } \\
\text { of the shore-parallel } \\
\text { canal and the } \\
\text { construction of } \\
\text { bulkheads. ( } 9 \text { 67). The } \\
\text { permit sought would } \\
\text { authorize (after-the- } \\
\text { fact) the connection of } \\
\text { the Sunset Acres } \\
\text { canals with the open } \\
\text { waters of Florida Bay. }\end{array}$ & 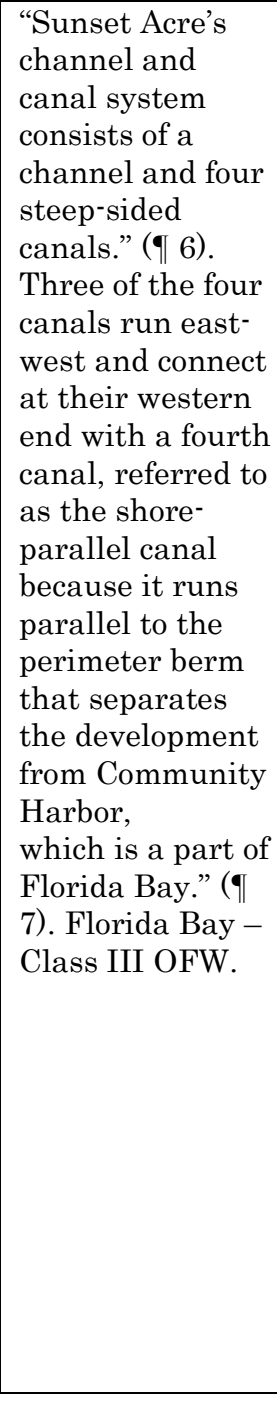 & $\begin{array}{l}\text { DEP denied a permit } \\
\text { application by Sunset to } \\
\text { connect to the then-closed } \\
\text { (but now open) canal } \\
\text { network in the Sunset } \\
\text { Acres subdivision by } \\
\text { removing a plug and } \\
\text { excavating two flushing } \\
\text { cuts through an earthen } \\
\text { berm separating the shore- } \\
\text { parallel canal from an } \\
\text { existing access channel. }\end{array}$ & $\begin{array}{l}\text { "Petitioner has not proposed, nor } \\
\text { has it agreed to, any mitigation } \\
\text { measures that likely would offset } \\
\text { the adverse effects of the } \\
\text { proposed project to such an } \\
\text { extent as to justify the issuance } \\
\text { of a permit." ( } ₫ \text { 75). However, } \\
\text { Petitioner has requested that the } \\
\text { Department, in the alternative, } \\
\text { approve a modified version of the } \\
\text { proposed project with the option } \\
\text { of either installing "three boat } \\
\text { lifts, one at the basin end of each } \\
\text { of the three finger canals," in lieu } \\
\text { of having notches in the } \\
\text { bulkheads, or "install[ing] a } \\
\text { single boat lift at the entrance } \\
\text { channel and clos[ing] the } \\
\text { entrance." ( } ₫ 77 \text {. }\end{array}$ & $\begin{array}{l}\text { Denied Petitioner's request } \\
\text { for a dredge and fill permit } \\
\text { for the proposed project } \\
\text { and granted Petitioner's } \\
\text { request for a dredge and } \\
\text { fill permit for the modified } \\
\text { proposed project. } \\
\text { Petitioner did not provide } \\
\text { reasonable assurance that } \\
\text { the proposed project will } \\
\text { not degrade the water } \\
\text { quality of Florida Bay. ( } ₫ \\
\text { 73). Also, the "Petitioner } \\
\text { failed to provide } \\
\text { reasonable assurance that } \\
\text { the proposed project is not } \\
\text { contrary to the public } \\
\text { interest (much less shown } \\
\text { that such activity is clearly } \\
\text { in the public interest)." ( } ₫ \\
74 \text { ). Specifically cited was } \\
\text { § } 373.4593, \text { Fla. Stat., } \\
\text { which "declar[ed] that an } \\
\text { emergency exists } \\
\text { regarding Florida Bay due } \\
\text { to an environmental crisis } \\
\text { manifested in widespread } \\
\text { die off of sea grasses, algae } \\
\text { blooms, and resulting } \\
\text { decreases in marine life, } \\
\text { conditions [which] } \\
\text { threaten the ecological } \\
\text { integrity of Florida Bay } \\
\text { and surrounding areas and } \\
\text { the economic viability of } \\
\text { Monroe County and the } \\
\text { State of Florida." ( } ₫ 71 \text { ). }\end{array}$ \\
\hline
\end{tabular}




\begin{tabular}{|c|c|c|c|c|c|}
\hline $\begin{array}{l}\text { Delcie Suto, et al. } \\
\text { v. Celebrity } \\
\text { Resorts, Inc. and } \\
\text { DER, Case no. 91- } \\
\underline{2722(1991)}\end{array}$ & $\begin{array}{l}\text { Permit for wastewater } \\
\text { treatment and reuse/ } \\
\text { disposal facility. }\end{array}$ & $\begin{array}{l}\text { Project located in } \\
\text { northern Marion } \\
\text { County on the } \\
\text { southern border of } \\
\text { Orange Lake, an } \\
\text { OFW. }\end{array}$ & $\begin{array}{l}\text { "Celebrity is seeking a DER } \\
\text { permit to construct a } 0.065 \\
\text { million gallon per day } \\
\text { wastewater treatment and } \\
\text { reuse/disposal facility to } \\
\text { serve a proposed recreation } \\
\text { vehicle (RV) park. ( } 1 \text { 1). } \\
\text { "The RV park is to be } \\
\text { located on } 75 \text { acres of land, } \\
\text { and is to contain } 372 \mathrm{RV} \\
\text { and 'park model' sites, four } \\
\text { bath houses, a clubhouse, } \\
\text { and an expanded } \\
\text { boathouse." ( }(2) \text {. }\end{array}$ & $\begin{array}{l}\text { No mitigation was discussed. } \\
\text { However, although the proposed } \\
\text { facility is not a highly } \\
\text { sophisticated plant, reasonable } \\
\text { assurances have been provided } \\
\text { that it will comply with DER's } \\
\text { requirements for secondary } \\
\text { treatment and basic disinfection } \\
\text { and proper operation. ( } \mathbf{q} 14) \text {. }\end{array}$ & $\begin{array}{l}\text { "Evidence presented in } \\
\text { this case indicates that } \\
\text { there is reasonable } \\
\text { assurance that none of the } \\
\text { applicable DER rules will } \\
\text { be violated by the } \\
\text { construction of the } \\
\text { [facility] and spray } \\
\text { irrigation system as } \\
\text { proposed by Celebrity } \\
\text { Resorts, Inc." }(\mathbb{\uparrow} 42) \text {. }\end{array}$ \\
\hline $\begin{array}{l}\text { Harold and } \\
\text { Charlotte Toms v. } \\
\text { FDEP and } \\
\text { Springs on King } \\
\text { Bay, Case no. 93- } \\
\underline{5724(1994)}\end{array}$ & $\begin{array}{l}\text { Dredge and fill permit } \\
\text { for Springs on King } \\
\text { Bay, a condominium } \\
\text { association, to } \\
\text { construct a } 12 \text {-slip } \\
\text { docking facility. }\end{array}$ & $\begin{array}{l}\text { Hunter Spring } \\
\text { Run - a Class III } \\
\text { OFW. }\end{array}$ & $\begin{array}{l}\text { FDEP issued an Intent to } \\
\text { Issue the requested permit. } \\
\text { Petitioners Harold and } \\
\text { Charlotte Toms filed a } \\
\text { challenge to the issuance of } \\
\text { the permit. (Order Denying } \\
\text { Amended Motion to Tax } \\
\text { Costs and Reasonable } \\
\text { Fees). The weight of the } \\
\text { evidence proved the } \\
\text { proposed facility would not } \\
\text { lower water quality } \\
\text { standards, would only have } \\
\text { temporary turbidity during } \\
\text { construction, would not } \\
\text { affect the public health, } \\
\text { safety, or welfare. ( } 1 \text { 18, 19, } \\
\text { and 21). }\end{array}$ & $\begin{array}{l}\text { Springs, in negotiation with } \\
\text { FDEP, amended the original } \\
\text { proposal to reduce the size of the } \\
\text { dock facility and agreed to a } \\
\text { conservation easement. "Because } \\
\text { of the conservation easement, the } \\
\text { cumulative impact of the } \\
\text { proposed project will be in the } \\
\text { public interest due to the } \\
\text { decrease in the potential number } \\
\text { of boat slips in the area." ( } ₫ 44) \text {. } \\
\text { Moreover, Springs agreed to a } \\
\text { number of measures to protect } \\
\text { manatees during and after } \\
\text { construction. }\end{array}$ & $\begin{array}{l}\text { Springs provided } \\
\text { reasonable assurance that, } \\
\text { based upon a balanced } \\
\text { consideration, the } \\
\text { proposed project is clearly } \\
\text { in the public interest. ( } 9 \\
59 \text { ). Petitioners offered no } \\
\text { evidence to rebut these } \\
\text { assurances. Section } \\
403.919(3) \text {, Florida } \\
\text { Statutes, requires a } \\
\text { consideration of the } \\
\text { cumulative impacts of the } \\
\text { proposed project. } \\
\text { Cumulative impacts of the } \\
\text { proposed project will be } \\
\text { minimized and, because of } \\
\text { the conservation } \\
\text { easement, will be in the } \\
\text { public interest. ( } 60 \text { ). }\end{array}$ \\
\hline $\begin{array}{l}\text { Robert } \\
\text { Vanwagoner (95- } \\
\text { 3621) and Save } \\
\text { Anna Maria, Inc. } \\
\text { and-3622) v. DOT } \\
\text { and DEP (1995) }\end{array}$ & $\begin{array}{l}\text { Department of } \\
\text { Transportation sought } \\
\text { a dredge and fill } \\
\text { permit for bridge } \\
\text { reconstruction. }\end{array}$ & $\begin{array}{l}\text { Anna Maria } \\
\text { Island Bridge is } \\
\text { about } 9000 \text { feet } \\
\text { south of the } \\
\text { confluence of } \\
\text { Sarasota Pass } \\
\text { and Lower } \\
\text { Tampa Bay. } \\
\text { Sarasota Pass }\end{array}$ & $\begin{array}{l}\text { Whether DOT is entitled to } \\
\text { a "dredge-and-fill permit } \\
\text { from DEP for the purpose of } \\
\text { demolishing the Manatee } \\
\text { Avenue drawbridge to Anna } \\
\text { Maria Island and } \\
\text { constructing a fixed-span, } \\
\text { high-level bridge } 20 \text { feet } \\
\text { south of the existing }\end{array}$ & $\begin{array}{l}\text { DOT has not minimized the } \\
\text { project by proposing the no-build } \\
\text { alternative, so consideration of } \\
\text { seagrass mitigation is } \\
\text { premature. ( } 193 \text { ). The seagrass } \\
\text { mitigation in this permit is } \\
\text { vague, unenforceable, and } \\
\text { ultimately nonexistent. "The } \\
\text { seagrass mitigation offered by }\end{array}$ & $\begin{array}{l}\text { Denied the DOT's } \\
\text { application for a dredge- } \\
\text { and fill permit. DOT failed } \\
\text { to provide reasonable } \\
\text { assurance that the } \\
\text { proposed project is clearly } \\
\text { in the public interest. } \\
\text { "DOT has provided no } \\
\text { reasonable assurance as to }\end{array}$ \\
\hline
\end{tabular}




\begin{tabular}{|c|c|c|c|c|c|}
\hline & & $\begin{array}{l}\text { connects to the } \\
\text { Tampa Bay } \\
\text { estuary to the } \\
\text { north and } \\
\text { Sarasota Bay } \\
\text { estuary to the } \\
\text { south. Sarasota } \\
\text { Pass and } \\
\text { Sarasota Bay are } \\
\text { OFWs. The } \\
\text { waters in the } \\
\text { vicinity of the } \\
\text { Bridge are Class } \\
\text { II waters. ( } ₫ \text { 58). }\end{array}$ & $\begin{array}{l}\text { bridge." The project is likely } \\
\text { to affect seagrass, } \\
\text { manatees, and mangrove. }\end{array}$ & $\begin{array}{l}\text { DOT is deficient in three } \\
\text { respects. First, the transplant } \\
\text { receiving site is too small. It is } \\
0.19 \text { acres as compared to the } \\
\text { likely permanent loss of } 2.5 \text { acres } \\
\text { and temporary loss of } 2.0 \text { acres. } \\
\text { The second deficiency is that the } \\
\text { primary seagrass mitigation is } \\
\text { too speculative. The third } \\
\text { deficiency of the seagrass } \\
\text { mitigation plan is its contingent } \\
\text { nature, which is perhaps } \\
\text { inevitable when the primary } \\
\text { seagrass mitigation plan is } \\
\text { widely conceded as unlikely to } \\
\text { succeed." (ף 87-95). }\end{array}$ & $\begin{array}{l}\text { five of the six applicable } \\
\text { criteria and has provided } \\
\text { reasonable assurance only } \\
\text { as to part of the sixth } \\
\text { criterion." ( } ₫ 183 \text { ). DOT } \\
\text { failed to provide } \\
\text { reasonable assurance that } \\
\text { the project would not lower } \\
\text { ambient water quality in } \\
\text { Sarasota Pass. "DEP and } \\
\text { DOT have not analyzed } \\
\text { the water-quality impacts } \\
\text { attributable to the } \\
\text { probable destruction of an } \\
\text { extensive area of seagrass. } \\
\text { Underestimating the } \\
\text { seagrass losses by an order } \\
\text { of magnitude and lacking } \\
\text { many important measures } \\
\text { of water quality, DOT } \\
\text { cannot provide reasonable } \\
\text { assurance that the } \\
\text { proposed project would not } \\
\text { degrade ambient water } \\
\text { quality in the area of the } \\
\text { bridge. To the contrary, } \\
\text { the proposed project would } \\
\text { likely degrade water } \\
\text { quality." ( } 111 \text { ). }\end{array}$ \\
\hline $\begin{array}{l}\text { Town of } \\
\text { Windermere v. } \\
\text { Orange County } \\
\text { Parks Dept. and } \\
\text { DER, Case nos. } \\
90-1782,90-1813, \\
\underline{90-2155,90-2156} \\
\underline{(1990)}\end{array}$ & $\begin{array}{l}\text { Orange County Parks } \\
\text { Department applied } \\
\text { for a dredge and fill } \\
\text { permit for } \\
\text { construction and } \\
\text { installation of a } \\
\text { floating boat dock to } \\
\text { accommodate boats } \\
\text { and pedestrians } \\
\text { loading and unloading } \\
\text { boats from an existing } \\
\text { boat ramp. }\end{array}$ & $\begin{array}{l}\text { The Butler } \\
\text { Chain of Lakes, } \\
\text { including } \\
\text { Lake Down, } \\
\text { Wauseon Bay, } \\
\text { and the } \\
\text { interconnecting } \\
\text { waterway - All } \\
\text { OFWs. (ף 93). }\end{array}$ & $\begin{array}{l}\text { Whether the "Orange } \\
\text { County Parks Department } \\
\text { is entitled to a dredge and } \\
\text { fill permit from the DER for } \\
\text { the construction and } \\
\text { installation of a boat dock } \\
\text { on Lake Down." }\end{array}$ & $\begin{array}{l}\text { "Suggestions that the dock could } \\
\text { be moved lakeward of its } \\
\text { proposed location were vague and } \\
\text { never crystallized into a formal } \\
\text { request to amend the application. } \\
\text { If such suggestions qualify as a } \\
\text { proffer of a mitigative condition, } \\
\text { the condition is concluded to be } \\
\text { insufficient." ( } ₫ 103) \text {. }\end{array}$ & $\begin{array}{l}\text { Orange County has failed } \\
\text { to provide reasonable } \\
\text { assurance that the } \\
\text { proposed project would not } \\
\text { result in a violation of } \\
\text { applicable ambient water } \\
\text { quality standards and has } \\
\text { failed to provide } \\
\text { reasonable assurance that } \\
\text { the proposed project is } \\
\text { clearly in the public } \\
\text { interest. (q 98-99). }\end{array}$ \\
\hline
\end{tabular}




\begin{tabular}{|c|c|c|c|c|c|}
\hline $\begin{array}{l}\text { Henry Ross v. } \\
\text { City of Tarpon } \\
\text { Springs and } \\
\text { FDEP, Case no. } \\
00-2100(2003) \\
0 \text { De }\end{array}$ & $\begin{array}{l}\text { City of Tarpon Springs } \\
\text { applied for an ERP } \\
\text { and lease to use } \\
\text { Sovereign Submerged } \\
\text { Lands for dredging } \\
\text { and maintenance } \\
\text { dredging of sediment } \\
\text { from eleven locations } \\
\text { in or adjacent to the } \\
\text { Anclote River and } \\
\text { surrounding bayous } \\
\text { and lagoons in order } \\
\text { to maintain/improve } \\
\text { navigation for } \\
\text { commercial and } \\
\text { recreational boating. }\end{array}$ & $\begin{array}{l}\text { Pinellas County } \\
\text { waters - all of } \\
\text { which are } \\
\text { designated } \\
\text { aquatic preserves } \\
\text { and OFWs. }\end{array}$ & $\begin{array}{l}\text { After Tarpon Springs } \\
\text { applied for the permits, } \\
\text { DER issued a notice of } \\
\text { intent to issue. Petitioner } \\
\text { challenged the intent to } \\
\text { issue. The issue is whether } \\
\text { Tarpon Springs should be } \\
\text { issued an ERP and } \\
\text { Authorization to Use } \\
\text { Sovereignty Submerged } \\
\text { Lands for the dredging of } \\
\text { existing channels in order } \\
\text { to improve/maintain } \\
\text { navigation for commercial } \\
\text { and recreational boaters. }\end{array}$ & $\begin{array}{l}\text { The City amended the original } \\
\text { application to address several of } \\
\text { DER's concerns. The modified } \\
\text { application "significantly } \\
\text { changed the whole concept of the } \\
\text { project from one that would } \\
\text { increase boating traffic to one } \\
\text { that would maintain the current } \\
\text { boating traffic." ( } \uparrow 16) \text {. However, } \\
\text { no additional mitigation was } \\
\text { offered. }\end{array}$ & $\begin{array}{l}\text { The evidence established } \\
\text { that the project will not } \\
\text { result in violations of the } \\
\text { water quality standards } \\
\text { nor degrade the ambient } \\
\text { water quality in an OFW. } \\
\text { The City provided } \\
\text { reasonable assurances } \\
\text { that its activities will not } \\
\text { adversely impact OFWs or } \\
\text { Class II waters and will } \\
\text { not contribute to boat } \\
\text { traffic in a manner that } \\
\text { will adversely impact the } \\
\text { manatee. The evidence } \\
\text { demonstrates that the } \\
\text { proposed activity is clearly } \\
\text { in the public interest. }\end{array}$ \\
\hline $\begin{array}{l}\text { Stanley Dominick, } \\
\text { et al. v. Leland } \\
\text { Egland and } \\
\text { FDEP, Case no. } \\
\underline{01-1540(2002)}\end{array}$ & $\begin{array}{l}\text { Leland Egland, } \\
\text { applied for an ERP "to } \\
\text { fill an illegally- } \\
\text { dredged trench or } \\
\text { channel in mangrove } \\
\text { wetlands between } \\
\text { Florida Bay and what } \\
\text { was a land-locked } \\
\text { lake, to restore } \\
\text { preexisting } \\
\text { conditions." }\end{array}$ & $\begin{array}{l}\text { Florida Bay- } \\
\text { Class III OFW. } \\
\text { The channel } \\
\text { connecting the } \\
\text { land-locked lake } \\
\text { to Florida Bay was } \\
\text { man-made and not } \\
\text { an OFW. } \\
\text { Manatees began } \\
\text { using the channel } \\
\text { to enter the lake } \\
\text { from Florida Bay. }\end{array}$ & $\begin{array}{l}\text { DEP issued a notice of } \\
\text { intent to issue the permit } \\
\text { and Petitioners challenged. } \\
\text { This issue is whether DEP } \\
\text { should grant the } \\
\text { application of Leland } \\
\text { Egland. }\end{array}$ & N/A & $\begin{array}{l}\text { Egland gave reasonable } \\
\text { assurance that filling the } \\
\text { trench or channel at issue } \\
\text { to restore preexisting } \\
\text { conditions will not degrade } \\
\text { the water quality of } \\
\text { Florida Bay. To the } \\
\text { contrary, "if the water } \\
\text { quality changes as a result } \\
\text { of this project, it will likely } \\
\text { improve since less lower- } \\
\text { quality water from South } \\
\text { Lake will enter Florida } \\
\text { Bay." (ף 35). Egland } \\
\text { provided reasonable } \\
\text { assurances that the } \\
\text { restoration project will not } \\
\text { adversely impact } \\
\text { manatees. (ף 40). } \\
\text { "Egland's evidence was } \\
\text { sufficient to provide } \\
\text { reasonable assurance that } \\
\text { his proposed restoration } \\
\text { project is clearly in the } \\
\text { public interest." (ף 41). }\end{array}$ \\
\hline
\end{tabular}




\begin{tabular}{|c|c|c|c|c|c|}
\hline $\begin{array}{l}\text { Singer Island } \\
\text { Civic Association, } \\
\text { Inc. and } 1000 \\
\text { Friends of } \\
\text { Florida, Inc. v. } \\
\text { Robert Simmons, } \\
\text { Jr., Little Munyon } \\
\text { Island of Palm } \\
\text { Beach County, } \\
\text { and DEP, Case } \\
\text { no. 01-1800 (2001) }\end{array}$ & 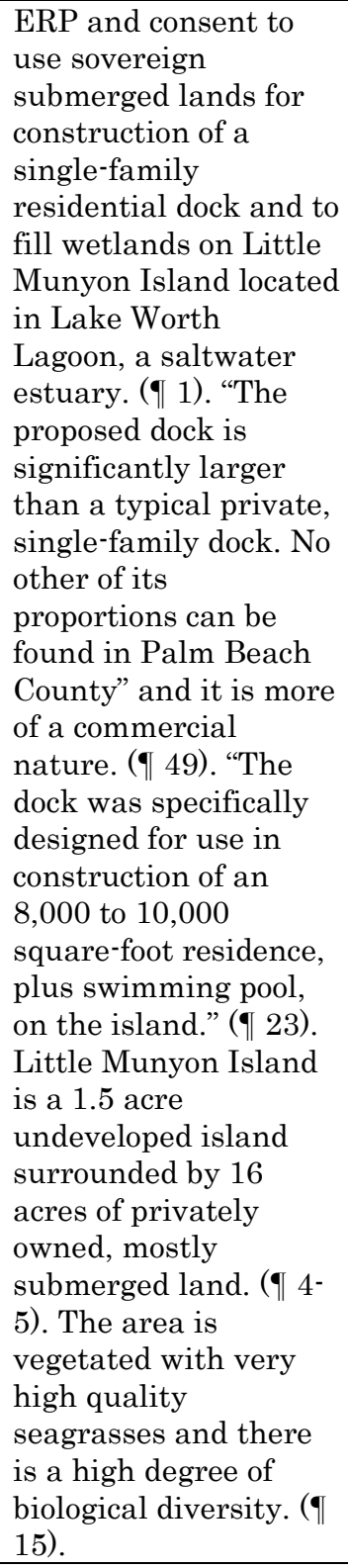 & $\begin{array}{l}\text { Little Munyon } \\
\text { Island is located } \\
\text { just south of the } \\
\text { John D. } \\
\text { MacArthur State } \\
\text { Park and Big } \\
\text { Munyon Island. } \\
\text { The Park waters } \\
\text { are Class II OFWs }\end{array}$ & $\begin{array}{l}\text { Whether Respondent, } \\
\text { Robert J. Simmons, Jr. } \\
\text { should be issued an ERP } \\
\text { and a Consent to Use } \\
\text { Sovereign Submerged } \\
\text { Lands to construct a } \\
\text { private, single-family, } \\
\text { residential dock for access } \\
\text { to Little Munyon Island and } \\
\text { to fill jurisdictional } \\
\text { wetlands on the island in } \\
\text { order to construct a } \\
\text { residence on the island. It } \\
\text { was estimated that, to fill } \\
\text { the island, if applicant } \\
\text { "used barges } 120-130 \text { feet } \\
\text { long and capable of hauling } \\
300 \text { tons of fill, he would } \\
\text { need to deliver } 27-30 \text { barge } \\
\text { loads of fill to the dock and } \\
\text { there is a reasonable } \\
\text { likelihood that some of this } \\
\text { fill will fall into the water." } \\
\text { ( } 94 \text { ). }\end{array}$ & 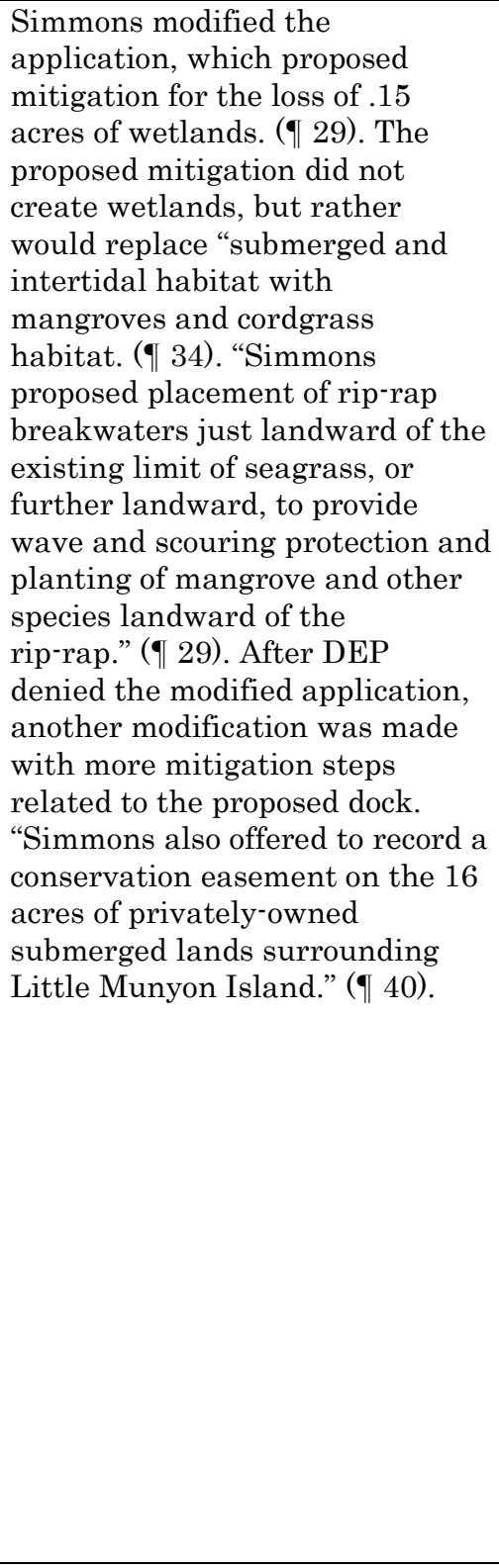 & $\begin{array}{l}\text { ALJ found the real } \\
\text { purpose of the dock was to } \\
\text { construct a } 8,000 \text { - } 10,000 \\
\text { square foot home. "A less } \\
\text { intense use of the island } \\
\text { would have fewer impacts } \\
\text { on the environment" and } \\
\text { alternatives were } \\
\text { available. ( } 150 \text { ). Damage } \\
\text { to the seagrasses will } \\
\text { result from direct } \\
\text { construction of the dock } \\
\text { and resulting shading. } \\
\text { Even if the dock was } \\
\text { shortened by } 35 \text { feet to } \\
\text { avoid the need to obtain } \\
\text { consent to use sovereign } \\
\text { submerged lands, the } \\
\text { water depths at the } \\
\text { alternative location would } \\
\text { be even shallower and } \\
\text { impacts on seagrasses } \\
\text { from scouring and } \\
\text { turbidity would be even } \\
\text { greater. ( } \$ \text { 85). "Simmons } \\
\text { did not provide reasonable } \\
\text { assurances that resulting } \\
\text { secondary impacts ... } \\
\text { would be acceptable." ( } \\
\text { 107). Even if the dock is } \\
\text { not shortened, there are } \\
\text { significant secondary } \\
\text { impacts to water quality } \\
\text { and seagrasses } \\
\text { surrounding Little } \\
\text { Munyon Island and } \\
\text { possible impacts on the } \\
\text { Class II OFW in } \\
\text { MacArthur State Park. } \\
\text { Risk of those impacts is } \\
\text { contrary to the public } \\
\text { interest. ( } \ 107 \text { ). }\end{array}$ \\
\hline
\end{tabular}




\begin{tabular}{|c|c|c|c|c|c|}
\hline $\begin{array}{l}\text { Daniel } \\
\text { Rothenberger, } \\
\text { Michael Irwin, } \\
\text { and Vernon } \\
\text { Powers v. } \\
\text { Southwest Florida } \\
\text { Water } \\
\text { Management } \\
\text { District and DOT, } \\
\text { Case no. 02-3423 } \\
\text { (2003) }\end{array}$ & $\begin{array}{l}\text { Florida Department of } \\
\text { Transportation } \\
\text { applied for an ERP "to } \\
\text { construct the Pinellas } \\
\text { Bayway Bridge } \\
\text { Replacement and } \\
\text { associated surface } \\
\text { water management } \\
\text { system." }\end{array}$ & $\begin{array}{l}\text { The existing } \\
\text { Pinellas Bayway } \\
\text { Bridge is a two- } \\
\text { lane bascule } \\
\text { structure located } \\
\text { within and } \\
\text { spanning Boca } \\
\text { Ciega Bay, an } \\
\text { OFW. }\end{array}$ & $\begin{array}{l}\text { Whether the DOT should be } \\
\text { granted an ERP } \\
\text { authorizing constructions of } \\
\text { "the Pinellas Bayway } \\
\text { Bridge Replacement and } \\
\text { associated surface water } \\
\text { management system." }\end{array}$ & $\begin{array}{l}\text { "The mitigation project to } \\
\text { compensate for impacts by the } \\
\text { Replacement Bridge to sea grass } \\
\text { beds within the affected surface } \\
\text { waters is a water circulation } \\
\text { project at Fort DeSoto Park, } \\
\text { located at the southern end of } \\
\text { Boca Ciega Bay," in the same } \\
\text { receiving waters where the } \\
\text { impacts will occur. (ף 31). }\end{array}$ & 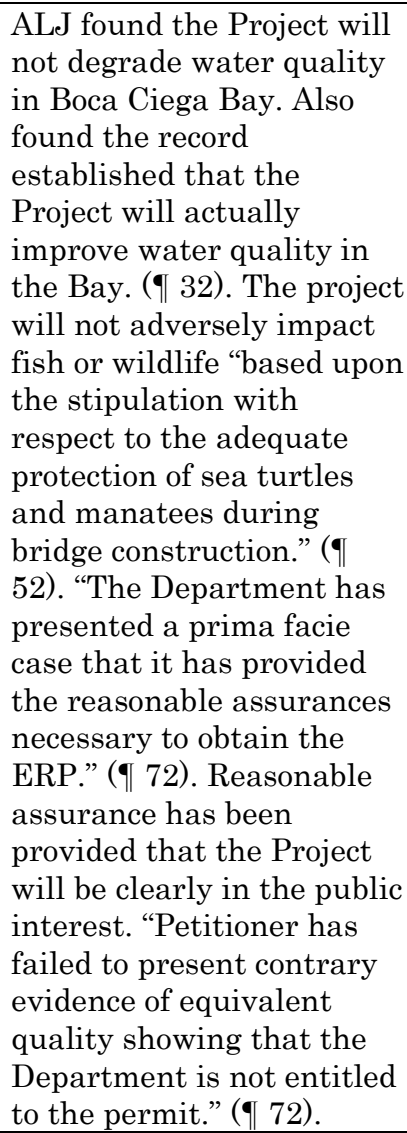 \\
\hline $\begin{array}{l}\text { Butler Chain } \\
\text { Concerned } \\
\text { Citizens, Inc. v. } \\
\text { Windermere } \\
\text { Botanical Garden, } \\
\text { L.P., and DEP, } \\
\text { Case no. 03-2471 } \\
\text { (2003) }\end{array}$ & $\begin{array}{l}\text { ERP for a muck- } \\
\text { removal project in an } \\
\text { eight-acre cove at the } \\
\text { northwest corner of } \\
\text { Lake Butler. } \\
\text { Windermere Botanical } \\
\text { Gardens sought to } \\
\text { remove invasive } \\
\text { aquatic vegetation } \\
\text { from wetlands within } \\
\text { the landward extent of } \\
\text { Lake Butler. }\end{array}$ & $\begin{array}{l}\text { Lake Butler, } \\
\text { part of the } \\
\text { Butler Chain of } \\
\text { Lakes, is an } \\
\text { OFW. }\end{array}$ & $\begin{array}{l}\text { Petitioners challenge DEP's } \\
\text { consent agreement with } \\
\text { WBG that, after the fact, } \\
\text { authorized WBG to remove } \\
\text { invasive aquatic vegetation. } \\
\text { Petitioners alleged the } \\
\text { scope of the work far } \\
\text { exceeded the work } \\
\text { permitted. Despite finding } \\
\text { multiple violations, DEP } \\
\text { issued the consent } \\
\text { agreement. }\end{array}$ & N/A & $\begin{array}{l}\text { Petitioner lacks standing } \\
\text { despite the } \\
\text { multidimensional role of } \\
\text { Lake Butler in the lives of } \\
\text { substantial numbers of its } \\
\text { members and WBG's } \\
\text { obvious violations of the } \\
\text { laws protecting OFWs and } \\
\text { governing the private use } \\
\text { of sovereign submerged } \\
\text { lands. Petitioner's } \\
\text { standing is precluded by } \\
\text { the fact that the record }\end{array}$ \\
\hline
\end{tabular}




\begin{tabular}{|c|c|c|c|c|c|}
\hline & & & & & $\begin{array}{l}\text { does not support a finding } \\
\text { that the acts and } \\
\text { omissions of WBG } \\
\text { contributed to any water } \\
\text { quality violations in Lake } \\
\text { Butler, including an algae } \\
\text { bloom that took place in } \\
\text { early August 2002. To the } \\
\text { contrary, the ALJ found } \\
\text { that the removal of the } \\
\text { tussock and muck from the } \\
\text { cove, especially in tandem } \\
\text { with the completion of the } \\
\text { revegetation required by a } \\
\text { 2001 permit, will improve } \\
\text { the water quality of Lake } \\
\text { Butler and add to the } \\
\text { diversity of the habitat } \\
\text { associated with the lake. } \\
\text { And, in the short run, the } \\
\text { berm and turbidity } \\
\text { barriers protected the open } \\
\text { waters of the lake from } \\
\text { construction- and } \\
\text { stormwater-related } \\
\text { turbidity. Under these } \\
\text { circumstances, Petitioner } \\
\text { lacked standing to dispute } \\
\text { the proposed agency action } \\
\text { of DEP in finalizing the } \\
\text { consent agreement with } \\
\text { WBG. ( } ₫ \text { 60-61). WBG's } \\
\text { multiple violations were } \\
\text { left to DEP to punish. }\end{array}$ \\
\hline $\begin{array}{l}\text { Bd. of Comm'rs of } \\
\text { Jupiter Inlet Div. } \\
\text { and Jeffery and } \\
\text { Andrea Cameron } \\
\text { and Doug Bogue } \\
\text { v. Paul Thibadeau } \\
\text { and DEP, Case } \\
\text { no. 03-4099 (2005) } \\
\end{array}$ & $\begin{array}{l}\text { ERP and } \\
\text { authorization to use } \\
\text { Sovereign Submerged } \\
\text { Lands for noticed } \\
\text { general permit to } \\
\text { construct a single } \\
\text { family dock. }\end{array}$ & $\begin{array}{l}\text { Loxahatchee } \\
\text { River-Lake Worth } \\
\text { Creek Aquatic } \\
\text { Preserve - Class } \\
\text { II OFW. }\end{array}$ & $\begin{array}{l}\text { Noticed general permit to } \\
\text { "install a } 900 \text { square-foot } \\
\text { dock comprising a three- } \\
\text { foot by } 250 \text {-foot access } \\
\text { walkway, a six-foot by } 25- \\
\text { foot terminal structure, and } \\
\text { two eight-foot by } 30 \text {-foot } \\
\text { boat slips - one a wetslip } \\
\text { and the other a boatlift" in }\end{array}$ & $\begin{array}{l}\text { "The platform covers submerged } \\
\text { bottom that is uncolonized by } \\
\text { seagrass, and, given its coarse } \\
\text { sand and shell hash, as well as } \\
\text { the water depths and water } \\
\text { clarity, this bottom is unlikely } \\
\text { ever to be colonized by seagrass. } \\
\text { The portion of the dock that } \\
\text { traverses seagrass will shade }\end{array}$ & $\begin{array}{l}\text { "The Revised Application } \\
\text { meets the requirements of } \\
\text { an NGP. It is a single- } \\
\text { family pier that will } \\
\text { accommodate the mooring } \\
\text { of no more than two boats. } \\
\text { The handrails and high } \\
\text { deck will discourage } \\
\text { mooring along the dock, }\end{array}$ \\
\hline
\end{tabular}




\begin{tabular}{|c|c|c|c|c|c|}
\hline & & & $\begin{array}{l}\text { the central embayment of } \\
\text { the Loxahatchee River in } \\
\text { Palm Beach County. }\end{array}$ & $\begin{array}{l}\text { this vegetation, but the effect of } \\
\text { shading is mitigated by the } \\
\text { seven-foot elevation of the deck, } \\
\text { translucency of the decking } \\
\text { material, and near north-south } \\
\text { orientation of the deck." ( } 128 \text { ). } \\
\text { "To mitigate for any cumulative } \\
\text { impacts to these resources, to } \\
\text { avoid adverse precedent for two } \\
\text { dock structures per parcel, and to } \\
\text { limit adverse precedent for } \\
\text { lengthy docks to comparable } \\
\text { water depths, the Letter of } \\
\text { Consent must contain the } \\
\text { condition - already agreed to by } \\
\text { Applicant - that he remove the } \\
\text { existing dock before constructing } \\
\text { the new dock." ( } ₫ \text { 66). }\end{array}$ & $\begin{array}{l}\text { and the terminal platform } \\
\text { is not designed to moor } \\
\text { safely more than two } \\
\text { boats. At the boat } \\
\text { moorings, the water depth } \\
\text { will be in excess of two feet } \\
\text { at mean low water. The } \\
\text { terminal platform and } \\
\text { moorings are not over } \\
\text { seagrass. The deck that } \\
\text { traverses seagrass is } \\
\text { elevated two feet more } \\
\text { than what is required in } \\
\text { the rule, and it is one foot } \\
\text { narrower than what is } \\
\text { permitted in the rule. The } \\
\text { platform and deck do not } \\
\text { significantly impede } \\
\text { navigation. Applicant will } \\
\text { conduct no dredging and } \\
\text { filling beyond what is } \\
\text { required to install the } \\
\text { pilings." ( } ₫ \text { 40-42). }\end{array}$ \\
\hline $\begin{array}{l}\text { Captiva Civic } \\
\text { Association, Inc. } \\
\text { et al. v. SFWMD } \\
\text { and Plantation } \\
\text { Development Ltd., } \\
\text { Case no. 06-0805 } \\
\underline{\text { (2006) }}\end{array}$ & $\begin{array}{l}\text { ERP for construction } \\
\text { and operation of a } \\
\text { surface water } \\
\text { management system } \\
\text { serving a 78.11-acre } \\
\text { condominium } \\
\text { development known as } \\
\text { Harbour Pointe at } \\
\text { South Seas Resort, } \\
\text { with discharge into } \\
\text { wetlands adjacent to } \\
\text { Pine Island Sound. }\end{array}$ & $\begin{array}{l}\text { Pine Island Sound } \\
\text { - Class II OFW. }\end{array}$ & $\begin{array}{l}\text { Whether the SWFWMD } \\
\text { should issue a ERP } \\
\text { Modification to Plantation } \\
\text { Development, Ltd. for } \\
\text { construction and operation } \\
\text { of a surface water } \\
\text { management system. "The } \\
\text { project will destroy and fill } \\
2.98 \text { acres of these } \\
\text { wetlands. Indirect } \\
\text { (secondary) impacts to the } \\
\text { adjacent preserved } \\
\text { wetlands will result from } \\
\text { alteration of hydrology of } \\
\text { the } 2.98 \text { acres of directly } \\
\text { impacted wetlands." ( } ₫ 50) \text {. }\end{array}$ & $\begin{array}{l}\text { "The proposed mitigation for the } \\
\text { mangrove impacts included: } \\
\text { restoration (by removal and } \\
\text { replanting) of . } 6 \text { acre of the } \\
\text { north-south sand/shell road, with } \\
\text { resulting enhancement of the } \\
\text { adjacent preserved mangrove } \\
\text { wetlands through improved } \\
\text { hydrologic connection across the } \\
\text { former shell/sand road and } \\
\text { improved tidal connection to Pine } \\
\text { Island Sound to the east; and } \\
\text { preservation of the rest of PDL's } \\
\text { property." ( } 17 \text { ) "A conservation } \\
\text { easement was offered for the } \\
73.31 \text { acres to be preserved, } \\
\text { including } 71.10 \text { acres of } \\
\text { wetlands. PDL also offered to } \\
\text { purchase .11 credits of offsite } \\
\text { mitigation from the Little Pine }\end{array}$ & $\begin{array}{l}\text { "The current condition and } \\
\text { relative value of the } \\
\text { functions being performed } \\
\text { by the areas affected by } \\
\text { the proposed activity are } \\
\text { very valuable. That is why } \\
\text { the reduction and } \\
\text { elimination analysis is } \\
\text { particularly important in } \\
\text { this case. Assuming } \\
\text { appropriate reduction and } \\
\text { elimination, mitigation } \\
\text { according to the UMAM } \\
\text { assessment can offset } \\
\text { unavoidable impacts to the } \\
\text { functions performed by the } \\
\text { areas affected by the } \\
\text { proposed activity." ( } ₫ \text { 79). } \\
\text { Moreover, "the proposed } \\
\text { system is not located in }\end{array}$ \\
\hline
\end{tabular}




\begin{tabular}{|c|c|c|c|c|c|}
\hline & & & & $\begin{array}{l}\text { Island Wetland Mitigation } \\
\text { Bank." ( } ₫ 19) \text {. A monitoring } \\
\text { program lasting at least five } \\
\text { years was offered to ensure } \\
\text { success of the restoration and } \\
\text { mitigation proposal. }\end{array}$ & $\begin{array}{l}\text { the Pine Island Sound } \\
\text { OFW; rather, it discharges } \\
\text { into adjacent wetlands. } \\
\text { Secondly, PDL offered the } \\
\text { unrebutted expert } \\
\text { testimony that the system } \\
\text { will not measurably } \\
\text { degrade Pine Island } \\
\text { Sound. Therefore, PDL's } \\
\text { burden was to provide } \\
\text { reasonable assurances } \\
\text { that the project is not } \\
\text { contrary to the public } \\
\text { interest" and they } \\
\text { provided such reasonable } \\
\text { assurances. ( } \mp 117) \text {. }\end{array}$ \\
\hline $\begin{array}{l}\text { Ian and Keli } \\
\text { Lineburger, et al. } \\
\text { v. Prospect } \\
\text { Marathon } \\
\text { Coquina and } \\
\text { FDEP, Case no. } \\
\underline{07-3757(2008)} \\
\end{array}$ & $\begin{array}{l}\text { ERP for construction } \\
\text { of a dock expansion to } \\
\text { serve a residential } \\
\text { condominium } \\
\text { development. Prospect } \\
\text { Marathon Coquina } \\
\text { (PMC) is the } \\
\text { developer. }\end{array}$ & $\begin{array}{l}\text { Big Bayou, near } \\
\text { the southern end } \\
\text { of the St. } \\
\text { Petersburg } \\
\text { peninsula. The } \\
\text { mouth of the } \\
\text { bayou opens to } \\
\text { Tampa Bay. Big } \\
\text { Bayou is part of } \\
\text { the Pinellas } \\
\text { County Aquatic } \\
\text { Preserve, which } \\
\text { includes most of } \\
\text { the coastal waters } \\
\text { of Pinellas } \\
\text { County. Pinellas } \\
\text { County Aquatic } \\
\text { Preserve is a } \\
\text { Class II water and } \\
\text { OFW. }\end{array}$ & $\begin{array}{l}\text { Whether PMC is entitled to } \\
\text { an ERP for the proposed } \\
\text { expansion of a docking } \\
\text { facility, and whether PMC } \\
\text { is entitled to a modified } \\
\text { sovereignty submerged land } \\
\text { lease for the proposed } \\
\text { project. }\end{array}$ & $\begin{array}{l}\text { PMC agreed to the following to } \\
\text { meet the public interest criteria: } \\
\text { (a) contribute } \$ 300,000 \text { to the } \\
\text { construction of a second boat } \\
\text { ramp at the current Sutherland } \\
\text { Bayou Boat Ramp project in } \\
\text { Palm Harbor; (b) install and } \\
\text { maintain navigational aides } \\
\text { marking the main channel in the } \\
\text { bayou; (c) install markers } \\
\text { indicating the location of } \\
\text { seagrass beds; (d) install and } \\
\text { maintain an informational } \\
\text { display at the public boat ramp } \\
\text { in Grandview Park, relating to } \\
\text { the protection of seagrasses and } \\
\text { natural resources within the } \\
\text { bayou; and (e) install and } \\
\text { maintain an aerial map at the } \\
\text { Grandview Park boat ramp } \\
\text { depicting the location of the } \\
\text { navigation channel and the } \\
\text { seagrass beds in the bayou. ( } \uparrow \\
\text { 56). }\end{array}$ & $\begin{array}{l}\text { Taking into account the } \\
\text { proposed conditions, the } \\
\text { adverse environmental } \\
\text { impacts would be } \\
\text { insignificant. However, the } \\
\text { second ramp would put } \\
\text { boats into waters where } \\
\text { there has been greater } \\
\text { seagrass losses, more prop } \\
\text { scarring, and more } \\
\text { manatees killed by boat } \\
\text { collisions than in Big } \\
\text { Bayou. PMC's contribution } \\
\text { to the boat ramp would } \\
\text { actually increase the } \\
\text { secondary and cumulative } \\
\text { impacts of PMC's proposed } \\
\text { project and causes it to fail } \\
\text { the public interest criteria. } \\
\text { Without the } \$ 300,000 \\
\text { contribution, PMC would } \\
\text { meet the "clearly in the } \\
\text { public interest" test } \\
\text { because the other } \\
\text { mitigation would offset the } \\
\text { impacts of the proposed } \\
\text { project." ( } ₫ \text { 61-61). }\end{array}$ \\
\hline
\end{tabular}




\begin{tabular}{|c|c|c|c|c|c|}
\hline $\begin{array}{l}\text { Normandy } \\
\text { Shores, LLC v. } \\
\text { DEP, Case no. 08- } \\
\underline{0217(2008)}\end{array}$ & $\begin{array}{l}\text { Exemption from ERP } \\
\text { requirements for the } \\
\text { construction of ten } \\
\text { docks to serve a } \\
\text { luxury townhome } \\
\text { community. }\end{array}$ & $\begin{array}{l}\text { Normandy } \\
\text { Waterway and } \\
\text { Indian Creek. } \\
\text { Both of these } \\
\text { waterbodies are in } \\
\text { the northern } \\
\text { portion of the } \\
\text { Biscayne Bay } \\
\text { Aquatic Preserve, } \\
\text { a Class III water } \\
\text { and OFW. }\end{array}$ & $\begin{array}{l}\text { Whether the applications } \\
\text { filed by Petitioner for an } \\
\text { exemption from ERP } \\
\text { requirements to construct } \\
\text { and install ten docks to } \\
\text { serve eighteen private boat } \\
\text { slips and a letter of consent } \\
\text { to use sovereign submerged } \\
\text { lands in Indian Creek, } \\
\text { within the Biscayne Bay } \\
\text { Aquatic Preserve, Miami } \\
\text { Beach, Florida, should be } \\
\text { approved. }\end{array}$ & No mitigation discussed. & $\begin{array}{l}\text { Because the private docks } \\
\text { were associated with } \\
\text { upland "multi-family } \\
\text { living complexes," and less } \\
\text { than } 65 \text { feet apart, the } \\
\text { project does not meet the } \\
\text { requirements of the rule } \\
\text { and cannot qualify for an } \\
\text { exemption. To qualify for a } \\
\text { letter of consent, the docks } \\
\text { must first qualify for an } \\
\text { exemption from ERP } \\
\text { requirements. ( } 98 \text { ). } \\
\text { Petitioner also failed to } \\
\text { show that the project will } \\
\text { not cause unacceptable } \\
\text { cumulative impacts: "the } \\
\text { more credible evidence } \\
\text { supports a finding that the } \\
\text { proposed activities will } \\
\text { cause direct and indirect } \\
\text { adverse impacts on the } \\
\text { Preserve's natural } \\
\text { systems, so that the } \\
\text { submerged lands and } \\
\text { associated waters will not } \\
\text { be maintained "essentially } \\
\text { in [their] natural or } \\
\text { existing condition" as } \\
\text { required by r. } 18 \text { - } \\
18.001(1) \text {, Fla. Admin. } \\
\text { Code. }\end{array}$ \\
\hline $\begin{array}{l}\text { Project Key West } \\
\text { and the Florida } \\
\text { Keys, Inc. d/b/a } \\
\text { Last Stand v. } \\
\text { Monroe County } \\
\text { and South Florida } \\
\text { Water } \\
\text { Management } \\
\text { District, Case no. } \\
\text { 08-3823 (2009) }\end{array}$ & $\begin{array}{l}\text { Modification to ERP } \\
\text { for an airport runway } \\
\text { safety area. }\end{array}$ & $\begin{array}{l}\text { Airport located in } \\
\text { the City of Key } \\
\text { West. There are } \\
\text { approximately } \\
\text { sixteen wetlands, } \\
\text { five surface } \\
\text { waters, and some } \\
\text { salt ponds in and } \\
\text { around the project } \\
\text { area. The salt } \\
\text { ponds are OFWs. }\end{array}$ & $\begin{array}{l}\text { Whether to approve an } \\
\text { application by Monroe } \\
\text { County to modify its ERP to } \\
\text { authorize the construction } \\
\text { and operation of Runway } \\
\text { Safety Area improvements } \\
\text { for the existing runway and } \\
\text { associated wetland } \\
\text { mitigation work at Key } \\
\text { West International Airport. }\end{array}$ & $\begin{array}{l}\text { The County proposes to } \\
\text { implement a mitigation proposal } \\
\text { at two different locations within } \\
\text { and adjacent to the Airport that } \\
\text { includes } 11.30 \text { acres of mangrove } \\
\text { swamp and tidal flat creation, } \\
3.64 \text { acres of bay and estuary } \\
\text { creation, } 5.21 \text { acres of wetland } \\
\text { enhancement, and } 0.96 \text { acres of } \\
\text { upland hammock enhancement, } \\
\text { for a total of } 21.11 \text { acres. ( }(13) \text {. }\end{array}$ & $\begin{array}{l}\text { Although Last Stand failed } \\
\text { to prove the elements of } \\
\text { associational standing, it } \\
\text { was allowed to fully } \\
\text { participate and litigate all } \\
\text { issues raised in its } \\
\text { Petition. "The County has } \\
\text { established its entitlement } \\
\text { to the requested } \\
\text { modification of its ERP. } \\
\text { Where conflicting evidence }\end{array}$ \\
\hline
\end{tabular}




\begin{tabular}{|c|c|c|c|c|c|}
\hline & & & & $\begin{array}{l}\text { In addition to Mitigation Area } \\
\text { Nos. } 1 \text { and } 2 \text {, which on their own } \\
\text { offset the wetland impacts, the } \\
\text { County agreed to preserve an } \\
\text { additional } 55 \text { acres of salt pond } \\
\text { habitat. These } 55 \text { acres are } \\
\text { referred to as Preservation Area } \\
\text { No. } 3 .\end{array}$ & $\begin{array}{l}\text { on the issues was } \\
\text { presented, the more } \\
\text { credible and persuasive } \\
\text { evidence was accepted in } \\
\text { favor of the applicant. } \\
\text { Therefore, the County's } \\
\text { application to modify its } \\
\text { existing ERP should be } \\
\text { approved." ( } ₫ \text { 109). }\end{array}$ \\
\hline $\begin{array}{l}\text { Bayshore } \\
\text { Homeowners } \\
\text { Association, et al. } \\
\text { v. DER and Grove } \\
\text { Isle, Inc., Case } \\
\text { nos. 79-2186, 79- } \\
\underline{2324,29-2354} \\
\underline{(1980)}\end{array}$ & $\begin{array}{l}\text { Water quality control } \\
\text { permit for the } \\
\text { construction of a 90- } \\
\text { boat wet-slip marina } \\
\text { on Grove Isle. }\end{array}$ & $\begin{array}{l}\text { Biscayne Bay- } \\
\text { Class III OFW. }\end{array}$ & $\begin{array}{l}\text { Whether Grove Isle has } \\
\text { provided reasonable } \\
\text { assurances that the } \\
\text { construction and operation } \\
\text { of the proposed marina will } \\
\text { not cause a violation of } \\
\text { state water quality } \\
\text { standards, will not interfere } \\
\text { with the conservation of } \\
\text { fish and other marine } \\
\text { wildlife, and will not create } \\
\text { a hazard to safe navigation } \\
\text { of Florida waters. }\end{array}$ & $\begin{array}{l}\text { No mitigation was discussed. } \\
\text { However, "the original plan for } \\
\text { the marina, which was objected } \\
\text { to by DER was modified to } \\
\text { protect a bed of seagrasses." ( } \\
\text { 1). DER attached several } \\
\text { conditions to the notice to issue } \\
\text { the permit, including: measures } \\
\text { to control turbidity, prohibition of } \\
\text { live-aboard vessels, water } \\
\text { markers, a chemical monitoring } \\
\text { program, and manatee warning } \\
\text { signs. }\end{array}$ & $\begin{array}{l}\text { Grove Isle failed to } \\
\text { demonstrate that its } \\
\text { project is affirmatively in } \\
\text { the "public interest" and it } \\
\text { is undetermined whether } \\
\text { the applicant can meet } \\
\text { ambient water quality } \\
\text { standards within the } \\
\text { project area. "After a } \\
\text { consideration of all the } \\
\text { foregoing factors, the } \\
\text { intent of the preservation } \\
\text { acts, and DER's rules, it is } \\
\text { concluded ... that the } \\
\text { greater benefit to the } \\
\text { greater number of } \\
\text { Floridians lies in denying } \\
\text { the application of Grove } \\
\text { Isle." (₫ 25). }\end{array}$ \\
\hline $\begin{array}{l}\frac{\text { Charlie Toppino }}{\text { \& Sons, Inc. v. }} \\
\text { DOT and DER, } \\
\text { Case no. 80-0854 } \\
\underline{(1980)}\end{array}$ & $\begin{array}{l}\text { Variance for } \\
\text { construction and } \\
\text { operation of a borrow } \\
\text { pit (mining operation) } \\
\text { in the Florida Keys to } \\
\text { provide fill material, } \\
\text { currently provided by } \\
\text { a pit in Cudjoe Key. }\end{array}$ & $\begin{array}{l}\text { Proposed site } \\
\text { comprised entirely } \\
\text { of tidally } \\
\text { inundated } \\
\text { wetland areas in } \\
\text { Key Deer Refuge, } \\
\text { in the Florida } \\
\text { Keys, an OFW. } \\
\text { The area is a } \\
\text { feeding ground for } \\
\text { the Florida Key } \\
\text { deer. }\end{array}$ & $\begin{array}{l}\text { DOT is seeking a variance } \\
\text { from various water quality } \\
\text { provisions to construct and } \\
\text { operate a "borrow pit" in } \\
\text { the Florida Keys. "The issue } \\
\text { in this proceeding is } \\
\text { whether the variance } \\
\text { sought by DOT should be } \\
\text { granted because of the } \\
\text { financial benefit that would } \\
\text { accrue to the State, or } \\
\text { denied because of adverse } \\
\text { environmental impacts." }\end{array}$ & No mitigation was discussed. & $\begin{array}{l}\text { Proposed borrow pit would } \\
\text { result in violations of } \\
\text { DER's standards for } \\
\text { dissolved oxygen. But, } \\
\text { operation of state-owned } \\
\text { borrow pit would save the } \\
\text { state money. Variance } \\
\text { request should be denied } \\
\text { because potential savings } \\
\text { were not established with } \\
\text { precision; the project is in } \\
\text { an OFW; and the adverse } \\
\text { environmental } \\
\text { consequences were } \\
\text { established with precision. }\end{array}$ \\
\hline
\end{tabular}




\begin{tabular}{|c|c|c|c|c|c|}
\hline $\begin{array}{l}\text { Wilber Walton v. } \\
\underline{\text { DER, Case no. 80- }} \\
\underline{2315(1981)}\end{array}$ & $\begin{array}{l}\text { Dredge and fill permit } \\
\text { for the construction of } \\
\text { a } 12 \text {-foot wide road } \\
\text { across approximately } \\
270 \text { feet of swampy } \\
\text { area dominated by } \\
\text { bald cypress. The } \\
\text { proposed fill would } \\
\text { result in permanent } \\
\text { elimination of at least } \\
3,240 \text { square feet of } \\
\text { area within the } \\
\text { landward extent of the } \\
\text { Suwannee River. }\end{array}$ & $\begin{array}{l}\text { Project site is a } \\
\text { tract of land } \\
\text { adjacent to the } \\
\text { Suwannee River } \\
\text { in Dixie County, } \\
\text { Florida. } \\
\text { Suwannee River } \\
\text { - Class III OFW. }\end{array}$ & $\begin{array}{l}\text { Whether petitioner has } \\
\text { established his entitlement } \\
\text { to the requested permit and } \\
\text { concomitantly whether the } \\
\text { proposed project will be in } \\
\text { the public interest and } \\
\text { whether it will have a } \\
\text { negative impact on the } \\
\text { waters of the state. }\end{array}$ & Mitigation not discussed. & $\begin{array}{l}\text { Project was clearly shown } \\
\text { to reduce the quality of the } \\
\text { receiving waters below the } \\
\text { classification established } \\
\text { for them, and exacerbate } \\
\text { the degradation of the } \\
\text { receiving waters of the } \\
\text { river already occasioned by } \\
\text { existing fill roads in the } \\
\text { swamp. Petitioner failed to } \\
\text { provide affirmative } \\
\text { reasonable assurances } \\
\text { that proposed project will } \\
\text { not result in violations of } \\
\text { water quality standards. A } \\
\text { preponderance of the } \\
\text { evidence demonstrates } \\
\text { clearly that the proposed } \\
\text { project will cause pollution } \\
\text { in contravention of the } \\
\text { Department's rules and } \\
\text { will result in violations of } \\
\text { the water quality } \\
\text { standards. Moreover, the } \\
\text { cumulative effect of } \\
\text { permitting the project is } \\
\text { great. }\end{array}$ \\
\hline $\begin{array}{l}\text { Raymond Hodges, } \\
\text { Jr. and Anne } \\
\text { Hodges v. DER, } \\
\text { Case no. 81-1088 } \\
\underline{(1981)}\end{array}$ & $\begin{array}{l}\text { Dredge and fill permit } \\
\text { for construction of } \\
\text { boat basin, boat ramp, } \\
\text { and a retaining wall. } \\
\text { The proposed dredging } \\
\text { operation would } \\
\text { connect the canal } \\
\text { system to the } \\
\text { navigable portion of } \\
\text { the Suwannee River. } \\
\text { The area in question } \\
\text { provides flood } \\
\text { protection and } \\
\text { controls } \\
\text { sedimentation. }\end{array}$ & $\begin{array}{l}\text { Tract of land } \\
\text { adjacent to and } \\
\text { partially within } \\
\text { the landward } \\
\text { extent of the } \\
\text { Suwannee River } \\
\text { in Dixie County, } \\
\text { Florida. The } \\
\text { Suwannee River } \\
\text { is a Class III } \\
\text { OFW. }\end{array}$ & $\begin{array}{l}\text { Whether Petitioners } \\
\text { provided affirmative } \\
\text { reasonable assurances that } \\
\text { the proposed project will } \\
\text { not result in violations of } \\
\text { the water quality standards } \\
\text { or Department rules and } \\
\text { whether the project will } \\
\text { cause pollution. }\end{array}$ & $\begin{array}{l}\text { No mitigation was discussed to } \\
\text { offset the numerous and serious } \\
\text { adverse affects of the project. }\end{array}$ & $\begin{array}{l}\text { Petitioner failed to provide } \\
\text { reasonable assurances } \\
\text { that project will not result } \\
\text { in violations of water } \\
\text { quality standards. Thus, } \\
\text { project is not in the public } \\
\text { interest. Preponderance of } \\
\text { the evidence also } \\
\text { demonstrates that the } \\
\text { project will cause pollution } \\
\text { in contravention of } \\
\text { Chapter 17, Fla. Admin. } \\
\text { Code. }\end{array}$ \\
\hline
\end{tabular}




\begin{tabular}{|c|c|c|c|c|c|}
\hline $\begin{array}{l}\text { DER v. Noel } \\
\text { Brown and } \\
\text { Carolyn Brown } \\
\text { Case no. } 81-2629 \\
\underline{(1981)}\end{array}$ & $\begin{array}{l}\text { Unauthorized filling } \\
\text { activities were } \\
\text { discovered during an } \\
\text { aerial inspection of } \\
\text { property along Yellow } \\
\text { River. The filling and } \\
\text { bulkheading activities } \\
\text { around a boat slip } \\
\text { occurred in an area } \\
\text { dominated by species } \\
\text { listed in r. } 17-4.02(17) \text {, } \\
\text { Fla. Admin. Code. }\end{array}$ & $\begin{array}{l}\text { Activities } \\
\text { occurred in the } \\
\text { Yellow River } \\
\text { marsh system. } \\
\text { The Yellow River } \\
\text { is classified as a } \\
\text { Class II water, an } \\
\text { Aquatic Preserve, } \\
\text { and an OFW. }\end{array}$ & $\begin{array}{l}\text { During an aerial inspection } \\
\text { in August 1980, a DER } \\
\text { employee noticed what } \\
\text { appeared to be } \\
\text { unauthorized filling } \\
\text { activities on Respondents' } \\
\text { property. The issues was } \\
\text { whether Respondents may } \\
\text { continue to operate and } \\
\text { maintain the stationary } \\
\text { installation, consisting of a } \\
\text { bulkhead and fill, on the } \\
\text { subject property without an } \\
\text { appropriate and valid } \\
\text { permit from DER. }\end{array}$ & $\begin{array}{l}\text { Mitigation was not discussed. } \\
\text { However, DER issued an Order } \\
\text { of Corrective Action that set forth } \\
\text { the following requirements: } \\
\text { Respondents (1) must stop } \\
\text { further dredging or filling, (2) } \\
\text { pay a fine to reimburse the } \\
\text { expenses of investigation, and (3) } \\
\text { submit a plan of the total } \\
\text { restoration of the area following } \\
\text { specific requirements of DER. ( } \\
\text { 11). }\end{array}$ & $\begin{array}{l}\text { Respondents' activities } \\
\text { were undertaken without } \\
\text { an appropriate and valid } \\
\text { permit. "The activities } \\
\text { resulted in the alteration } \\
\text { of the chemical, physical, } \\
\text { and biological integrity of } \\
\text { the waters of the Yellow } \\
\text { River, including the marsh } \\
\text { area fringing the river, by } \\
\text { the destruction of wetlands } \\
\text { which provide food and } \\
\text { habitat for wildlife, and } \\
\text { which provide a filtrative } \\
\text { and assimilative capacity } \\
\text { to remove nutrients and } \\
\text { other pollutants from the } \\
\text { lake waters. The discharge } \\
\text { of fill onto the marsh areas } \\
\text {.. resulted in injury to the } \\
\text { biological community that } \\
\text { existed there." ( } 9 \text { 9). The } \\
\text { discharge of fill "has } \\
\text { resulted in injury, and in } \\
\text { the obliteration of animal, } \\
\text { plant, and aquatic life.” ( } ~ \\
23) \text {. Thus, the Respondents } \\
\text { have violated } § \\
\text { 403.161(1)(a), Fla. Stat. }\end{array}$ \\
\hline $\begin{array}{l}\text { George DeCarion } \\
\text { and James } \\
\text { Roberts v. DER, } \\
\text { Case no. 81-3242 } \\
\underline{(1982)}\end{array}$ & $\begin{array}{l}\text { Dredged and fill } \\
\text { permit from DER to } \\
\text { construct an upland } \\
\text { canal and access } \\
\text { channels for a private, } \\
\text { 70-acre, residential } \\
\text { development on Key } \\
\text { Largo in Monroe } \\
\text { County, Florida. }\end{array}$ & $\begin{array}{l}\text { John Pennekamp } \\
\text { Coral Reef State } \\
\text { Park is a Class III } \\
\text { OFW renowned } \\
\text { for its unique } \\
\text { coral reef } \\
\text { formation and a } \\
\text { diversity of } \\
\text { marine organisms. }\end{array}$ & $\begin{array}{l}\text { Whether any portion of this } \\
\text { project, specifically the } \\
\text { northern circulation } \\
\text { channel, lies within the } \\
\text { boundaries of the John } \\
\text { Pennekamp Coral Reef } \\
\text { State Park. }\end{array}$ & $\begin{array}{l}\text { Petitioners propose to recreate a } \\
\text { similar number of mangroves as } \\
\text { are removed by the dredging and } \\
\text { to replant seagrasses in the } \\
\text { proposed channels. However, } \\
\text { "the probability of a successful } \\
\text { replanting of seagrasses in the } \\
\text { proposed artificial canal and } \\
\text { access channels was not } \\
\text { adequately demonstrated by the } \\
\text { evidence in this proceeding." ( } \\
\text { 19). }\end{array}$ & $\begin{array}{l}\text { "For purposes of locating a } \\
\text { boundary, the physical } \\
\text { location of a monument } \\
\text { controls over written calls } \\
\text { of its location." ( } 1 \text { 14). It } \\
\text { was determined that the } \\
\text { project site was not within } \\
\text { the Park boundaries, but } \\
\text { located approximately } 363 \\
\text { feet south of the Park's } \\
\text { southerly boundary. "The } \\
\text { petitioners have failed to } \\
\text { affirmatively provide } \\
\text { reasonable assurances }\end{array}$ \\
\hline
\end{tabular}




\begin{tabular}{|c|c|c|c|c|c|}
\hline & & & & & $\begin{array}{l}\text { that the construction of a } \\
4,400 \text { foot long upland } \\
\text { canal with access } \\
\text { channels, and the } \\
\text { consequent destruction of } \\
\text { mangroves and grass bed } \\
\text { communities, will not } \\
\text { cause violations of the } \\
\text { State water quality } \\
\text { standards regarding } \\
\text { dissolved oxygen and } \\
\text { biological integrity. The } \\
\text { petitioners have likewise } \\
\text { failed to demonstrate that } \\
\text { their project, located in } \\
\text { close proximity to the John } \\
\text { Pennekamp Coral Reef } \\
\text { State Park, will not cause } \\
\text { environmental damage to } \\
\text { such an extent as to be } \\
\text { contrary to the public } \\
\text { interest." ( } ₫ 21 \text { ). Thus, the } \\
\text { petitioners have failed to } \\
\text { provide reasonable } \\
\text { assurances that the short- } \\
\text { and long-term effects of } \\
\text { the proposed activity will } \\
\text { not violate water quality } \\
\text { standards for Class III } \\
\text { waters and will not } \\
\text { significantly degrade the } \\
\text { OFW located just } \\
363 \text { feet to the north. }\end{array}$ \\
\hline $\begin{array}{l}\text { Sierra Club, } \\
\text { Calusa Group, c/o } \\
\text { Ellen Peterson, } \\
\text { Co-chair v. Lee } \\
\text { County, Black } \\
\text { Island Resort, and } \\
\text { DER, Case no. 82- } \\
0159(1982)\end{array}$ & $\begin{array}{l}\text { Three permits for a } \\
\text { sewage treatment } \\
\text { plant, disposal system, } \\
\text { and reverse osmosis } \\
\text { water treatment } \\
\text { plant. }\end{array}$ & $\begin{array}{l}\text { Groundwater at } \\
\text { the drain field } \\
\text { site mixes with } \\
\text { the surrounding } \\
\text { waters within } \\
\text { Estero Bay } \\
\text { Aquatic } \\
\text { Preserve, a } \\
\text { OFW. }\end{array}$ & $\begin{array}{l}\text { Whether the proposed } \\
\text { sewage treatment plant and } \\
\text { attendant waste disposal } \\
\text { system will violate water } \\
\text { quality standards. }\end{array}$ & No mitigation discussed. & $\begin{array}{l}\text { Applicant did not provide } \\
\text { reasonable assurance that } \\
\text { the nutrient pollutants } \\
\text { involved will not constitute } \\
\text { significant degradation of } \\
\text { the OFW, will not lower } \\
\text { existing ambient water } \\
\text { quality, or that the project } \\
\text { is clearly in the public } \\
\text { interest. Permit denied. }\end{array}$ \\
\hline
\end{tabular}




\begin{tabular}{|c|c|c|c|c|c|}
\hline $\begin{array}{l}\text { Richard } \\
\text { Buchanan v. } \\
\text { DER, Case no. 82- } \\
\underline{3543(1983)}\end{array}$ & $\begin{array}{l}\text { Permit to dredge an } \\
\text { access channel. }\end{array}$ & $\begin{array}{l}\text { Apalachicola Bay } \\
\text { - Class III OFW. }\end{array}$ & $\begin{array}{l}\text { Whether petitioner should } \\
\text { be authorized to dredge a } \\
\text { channel to restore the } \\
\text { access he had to deeper } \\
\text { water before another's } \\
\text { illegal "prop-dredging" } \\
\text { caused sediment to } \\
\text { accumulate and block his } \\
\text { access. Before the } \\
\text { disturbance, the } \\
\text { configuration of the bottom } \\
\text { allowed small boats to come } \\
\text { all the way into shore. }\end{array}$ & $\begin{array}{l}\text { Rule } 17-4.28(8) \text { (a), Fla. Admin. } \\
\text { Code, requires a plan for } \\
\text { minimization of the } \\
\text { environmental effects of projects } \\
\text { of this kind. Ordinarily, it would } \\
\text { fall to the applicant to devise } \\
\text { such a plan to conserve } \\
\text { Departmental resources. In the } \\
\text { present case, however, "where } \\
\text { petitioner is volunteering to } \\
\text { effect partial restoration at his } \\
\text { own expense, it would be } \\
\text { oppressive to saddle him with the } \\
\text { additional burden of retaining } \\
\text { persons with the expertise } \\
\text { necessary to formulate such a } \\
\text { plan, particularly when } \\
\text { respondent, whose interests } \\
\text { petitioner is advancing, has } \\
\text { persons with such expertise in its } \\
\text { employ." ( } ₫ 18 \text { ). }\end{array}$ & $\begin{array}{l}\text { "It is very clearly in the } \\
\text { public interest to allow a } \\
\text { citizen, at his own } \\
\text { expense, to restore } \\
\text { bottomlands to the } \\
\text { condition in which they } \\
\text { existed for decades before } \\
\text { illegal activities of a } \\
\text { stranger altered them, } \\
\text { especially where the } \\
\text { citizen alerted the } \\
\text { authorities to the illegal } \\
\text { activities while they were } \\
\text { in progress." Neither } \\
\text { petitioner nor any } \\
\text { predecessor in title was } \\
\text { responsible for the sudden } \\
\text { man-made transformation. } \\
\text { Petitioner complained to } \\
\text { the appropriate authorities } \\
\text { contemporaneously with } \\
\text { the illegal acts that caused } \\
\text { the problem and took steps } \\
\text { to prevent the illegal } \\
\text { damage. "It is sound policy } \\
\text { to encourage such } \\
\text { participation by citizens in } \\
\text { protecting the } \\
\text { environment." ( } 17 \text { ). } \\
\text { Evidence didn't suggest } \\
\text { any long-term adverse, } \\
\text { cumulative, environmental } \\
\text { impact, if petitioner's } \\
\text { proposed project was } \\
\text { allowed. ( } 14 \text { ). Permit } \\
\text { granted "on such } \\
\text { reasonable conditions, } \\
\text { including turbidity } \\
\text { curtains, as are necessary } \\
\text { adequately to protect the } \\
\text { project vicinity." } \\
\text { (Recommended Order at } \\
\text { 6). }\end{array}$ \\
\hline
\end{tabular}




\begin{tabular}{|c|c|c|c|c|c|}
\hline $\begin{array}{l}\text { Joel Beardsley et } \\
\text { al.v. Mark } \\
\text { Bartecki and } \\
\text { DER, Case no. } 83 \text { - } \\
\text { 1532(1983) }\end{array}$ & $\begin{array}{l}\text { Permit to construct a } \\
\text { dock and boat slips. } \\
\text { "The proposed dock } \\
\text { would be the first } \\
\text { structure of its type } \\
\text { permitted by DER on } \\
\text { Cudjoe Bay." (ब 13). }\end{array}$ & $\begin{array}{l}\text { Cudjoe Bay - } \\
\text { Class III OFW } \\
\text { within the Key } \\
\text { Deer National } \\
\text { Wildlife Refuge. }\end{array}$ & $\begin{array}{l}\text { Mark Bartecki and } \\
\text { associates are seeking } \\
\text { various governmental } \\
\text { approvals for construction } \\
\text { of a } 50-\text {-unit duplex housing } \\
\text { development on } 25 \text { lots on } \\
\text { the shore of Cudjoe Bay. } \\
\text { Bartecki initially sought } \\
\text { mooring facilities for as } \\
\text { many as } 25 \text { boats, but } \\
\text { through negotiations with } \\
\text { the Department amended } \\
\text { the application to provide } \\
\text { that no more than eight } \\
\text { boat slips and eight boats } \\
\text { will be accommodated. } \\
\text { Issue is whether permit } \\
\text { should be granted. }\end{array}$ & $\begin{array}{l}\text { Bartecki's planned to mark a } \\
\text { channel which would help reduce } \\
\text { random boat traffic and } \\
\text { concentrate boat traffic in the } \\
\text { marked lane so as to reduce } \\
\text { consequential propeller damage } \\
\text { to grass beds in a wider area of } \\
\text { Cudjoe Bay. }\end{array}$ & $\begin{array}{l}\text { "[N]o such construction } \\
\text { [should] be permitted in } \\
\text { waters accorded this high } \\
\text { degree of protection unless } \\
\text { the public will actually be } \\
\text { substantially served by the } \\
\text { installation of such a } \\
\text { facility." ( } 1 \text { 25). Although } \\
\text { applicant affirmatively } \\
\text { demonstrated reasonable } \\
\text { assurances that the project } \\
\text { would be environmentally } \\
\text { palatable, he has } \\
\text { nevertheless failed to meet } \\
\text { the heavy burden of the } \\
\text { "public interest test." } \\
\text { Permit denied. } \\
\text { ***REVERSED by the } \\
\text { District Court of Appeal } \\
\text { for the First District in } \\
\text { holding that "Denial by the } \\
\text { [DER] of a permit to } \\
\text { construct a dock adjacent } \\
\text { to applicant's property, } \\
\text { based on applicant's } \\
\text { failure to show that the } \\
\text { project was clearly in the } \\
\text { public interest, was } \\
\text { erroneous, as reflected in } \\
\text { contemporaneous case in } \\
\text { which imposition of such a } \\
\text { public interest } \\
\text { requirement prior to } \\
\text { issuance of construction } \\
\text { permit for stationary } \\
\text { installation not involving } \\
\text { the discharge of waste into } \\
\text { state waters was an } \\
\text { invalid exercise of } \\
\text { delegated authority." }\end{array}$ \\
\hline
\end{tabular}




\begin{tabular}{|c|c|c|c|c|c|}
\hline $\begin{array}{l}\frac{\text { Craig Zabin (84- }}{\text { 0358) and Judy }} \\
\text { Ryan and Robert } \\
\text { Sampson (84- } \\
\text { 0449) v. Brevard } \\
\text { County and DER } \\
\underline{(1984)}\end{array}$ & $\begin{array}{l}\text { Permit to construct a } \\
\text { sludge wastewater } \\
\text { treatment plan } \\
\text { utilizing chemical } \\
\text { additives, a tertiary } \\
\text { sand filter, } \\
\text { disinfection by } \\
\text { chlorination, and } \\
\text { effluent disposal to a } \\
\text { drainage canal and } \\
\text { then to Newfound } \\
\text { Harbor. }\end{array}$ & $\begin{array}{l}\text { Effluent will be } \\
\text { discharged into a } \\
\text { ditch that } \\
\text { eventually } \\
\text { intersects with } \\
\text { Newfound Harbor. } \\
\text { At that point the } \\
\text { Harbor waters are } \\
\text { classified as Class } \\
\text { III waters. A } \\
\text { portion of the } \\
\text { Harbor, well to } \\
\text { the south of the } \\
\text { discharge point, is } \\
\text { classified as an } \\
\text { OFW. The } \\
\text { discharge would } \\
\text { not have an } \\
\text { impact that was } \\
\text { technically } \\
\text { measurable on } \\
\text { that portion of } \\
\text { Newfound Harbor. }\end{array}$ & $\begin{array}{l}\text { Whether a permit should be } \\
\text { issued to Brevard County } \\
\text { authorizing the } \\
\text { construction of certain } \\
\text { modifications to its } \\
\text { Fortenberry wastewater } \\
\text { treatment and disposal } \\
\text { plant in Merritt Island, } \\
\text { Florida. Petitioners contend } \\
\text { that the construction would } \\
\text { result in the discharge of } \\
\text { effluent containing toxic } \\
\text { substances into an OFW. } \\
\text { Furthermore, petitioners } \\
\text { contend that the plant has } \\
\text { no operating permit, that it } \\
\text { has violated "discharge } \\
\text { standards" for the last three } \\
\text { years, and that the plant's } \\
\text { present discharge is } \\
\text { harmful to human health } \\
\text { and aquatic life in violation } \\
\text { of various DER rules. }\end{array}$ & $\begin{array}{l}\text { No mitigation was discussed. } \\
\text { However, the draft permit } \\
\text { authorized the activity subject to } \\
\text { fifteen general and ten specific } \\
\text { conditions. ( } ₫ \text { 3). }\end{array}$ & $\begin{array}{l}\text { Applicant provided } \\
\text { reasonable assurance that } \\
\text { the proposed } \\
\text { improvements to the } \\
\text { Fortenberry Plant will } \\
\text { comply with the various } \\
\text { standards and not } \\
\text { discharge, emit, or cause } \\
\text { pollution in contravention } \\
\text { of Department standards } \\
\text { or rules. The permit is } \\
\text { granted in accordance with } \\
\text { the terms and conditions of } \\
\text { the draft permit. "The } \\
\text { construction of the } \\
\text { improvements authorized } \\
\text { by the permit should not } \\
\text { be delayed since the } \\
\text { Fortenberry Plant is } \\
\text { currently violating its } \\
\text { waste load allocation and } \\
\text { polluting the waters of } \\
\text { Newfound Harbor." (q 13). }\end{array}$ \\
\hline $\begin{array}{l}\text { Sierra Club, et al. } \\
\text { v. DER and Port } \\
\text { Bouganville, Inc. } \\
\text { Case nos. 84- } \\
2364,84-2365,84- \\
\underline{2385,84-2327:} \\
\underline{(1984)}\end{array}$ & $\begin{array}{l}\text { Seeking authorization } \\
\text { to modify an existing } \\
\text { boat basin and marina } \\
\text { on northern Key Largo } \\
\text { Florida. The facility is } \\
\text { designed to serve a } \\
\text { real estate } \\
\text { development. }\end{array}$ & $\begin{array}{l}\text { Existing boat } \\
\text { basin in marina } \\
\text { lies on northern } \\
\text { Key Largo in } \\
\text { Monroe County, } \\
\text { adjacent to } \\
\text { Garden Cove, an } \\
\text { embayment of } \\
\text { the Atlantic } \\
\text { Ocean. Garden } \\
\text { Cove is a Class } \\
\text { III OFW. Marina } \\
\text { is also on the } \\
\text { western edge of } \\
\text { John Pennekamp } \\
\text { Coral Reef State } \\
\text { Park, an OFW. }\end{array}$ & $\begin{array}{l}\text { Whether an existing } \\
\text { marina, already authorized } \\
\text { by DER, DNR and by the } \\
\text { "Development of } \\
\text { Regional Impact" } \\
\text { Development Order, should } \\
\text { be granted an application } \\
\text { for modification and } \\
\text { reconstruction. In addition, } \\
\text { whether the marina } \\
\text { modification project will } \\
\text { comport with the various } \\
\text { water quality, marine life } \\
\text { protection and } \\
\text { environmental safety } \\
\text { parameters, and if so, } \\
\text { whether and under what } \\
\text { conditions, the permit } \\
\text { should be issued. }\end{array}$ & $\begin{array}{l}\text { Port Bougainville agreed to } \\
\text { modify the marina to shoal the } \\
\text { marina basin and canal system } \\
\text { to a depth of no more than } \\
\text { - } 4 \text { feet mean low water at the } \\
\text { north end of the basin and - } 6 \text { feet } \\
\text { in other areas; to reduce the } \\
\text { capacity of the marina to } 311 \\
\text { boat slips; to install a bubble } \\
\text { screen around the fueling } \\
\text { facilities and relocate those } \\
\text { facilities; to provide for marking } \\
\text { of the access channel and } \\
\text { installing tidal gauges at the } \\
\text { entrance; to reconfigure the } \\
\text { access channel; to grant the } \\
\text { Department a conservation } \\
\text { easement providing that there } \\
\text { would be no connection between } \\
\text { the marina and certain upland }\end{array}$ & $\begin{array}{l}\text { The Department shall } \\
\text { issue a permit to Port } \\
\text { Bougainville to make the } \\
\text { proposed modifications to } \\
\text { the marina. It was } \\
\text { established that "the } \\
\text { modification of the marina } \\
\text { as proposed will actually } \\
\text { be clearly in the public } \\
\text { interest inasmuch as it } \\
\text { will substantially improve } \\
\text { the existing marina." ( } \\
\text { 43). "Moreover, the } \\
\text { evidence clearly shows } \\
\text { that the activity sought to } \\
\text { be permitted will not } \\
\text { 'significantly degrade' the } \\
\text { waters of Pennekamp Park } \\
\text { either alone or in } \\
\text { combination with other }\end{array}$ \\
\hline
\end{tabular}




\begin{tabular}{|c|c|c|c|c|c|}
\hline & & & & $\begin{array}{l}\text { lakes, that Port Bougainville } \\
\text { would not use boat lifts requiring } \\
\text { dredging and filling, that it } \\
\text { would not apply to increase the } \\
\text { number of boat slips above } 311 \text {, } \\
\text { and that it would take certain } \\
\text { precautions to protect John } \\
\text { Pennekamp State Park. }\end{array}$ & $\begin{array}{l}\text { existing installations. } \\
\text { Thus, it has not been } \\
\text { established that the OFW } \\
\text { rule will actually apply, } \\
\text { [as it was not established } \\
\text { that] the modifications to } \\
\text { the marina will } \\
\text { significantly degrade these } \\
\text { [OFW]." ( } 944 \text { ). Permit } \\
\text { granted subject to the } \\
\text { conditions incorporated in } \\
\text { the agreement and the } \\
\text { conservation easement. A } \\
\text { further condition was } \\
\text { added to the conservation } \\
\text { easement that the } \\
\text { deposition of boats from } \\
\text { the inland lakes system } \\
\text { into the marina and its } \\
\text { access canal be } \\
\text { prohibited." (RO pg. 22). }\end{array}$ \\
\hline $\begin{array}{l}\text { Jolly Rogers } \\
\text { Estate Property } \\
\text { Owners } \\
\text { Association, Inc. } \\
\text { v. Charles } \\
\text { Loverino and } \\
\text { DER, Case no. 84- } \\
\text { 2716 (1984) }\end{array}$ & $\begin{array}{l}\text { Permit to construct a } \\
165 \text {-foot extension to } \\
\text { an already existing } \\
\text { wooden dock. }\end{array}$ & $\begin{array}{l}\text { National Key } \\
\text { Deer Refuge and } \\
\text { Pine Channel, } \\
\text { classified as an } \\
\text { OFW. }\end{array}$ & $\begin{array}{l}\text { Whether permit should be } \\
\text { granted to construct a } 165 \text { - } \\
\text { foot long by } 6 \text {-foot wide } \\
\text { extension to his present } \\
\text { wooden dock. "The dock will } \\
\text { run parallel to an existing } \\
\text { canal which serves as the } \\
\text { main entrance channel to } \\
\text { Jolly Roger Estates, a } \\
\text { subdivision which is } \\
\text { currently being developed, } \\
\text { and which possesses a } \\
\text { network of dead end } \\
\text { canals." ( } ₫ 2 \text {. }\end{array}$ & No mitigation discussed. & $\begin{array}{l}\text { No evidence was } \\
\text { introduced that proved the } \\
\text { project would lower } \\
\text { existing ambient water } \\
\text { quality. "The existence of } \\
\text { the proposed dock } \\
\text { extension will have no } \\
\text { effect on ambient water } \\
\text { quality itself." ( } 1 \text { 15). } \\
\text { Petitioners were concerned } \\
\text { that live-aboards would } \\
\text { adversely affect water } \\
\text { quality. "However, DER's } \\
\text { proposed permit conditions } \\
\text { would prohibit live- } \\
\text { aboards from utilizing the } \\
\text { proposed dock extension." } \\
\text { ( } 15) \text {. }\end{array}$ \\
\hline
\end{tabular}




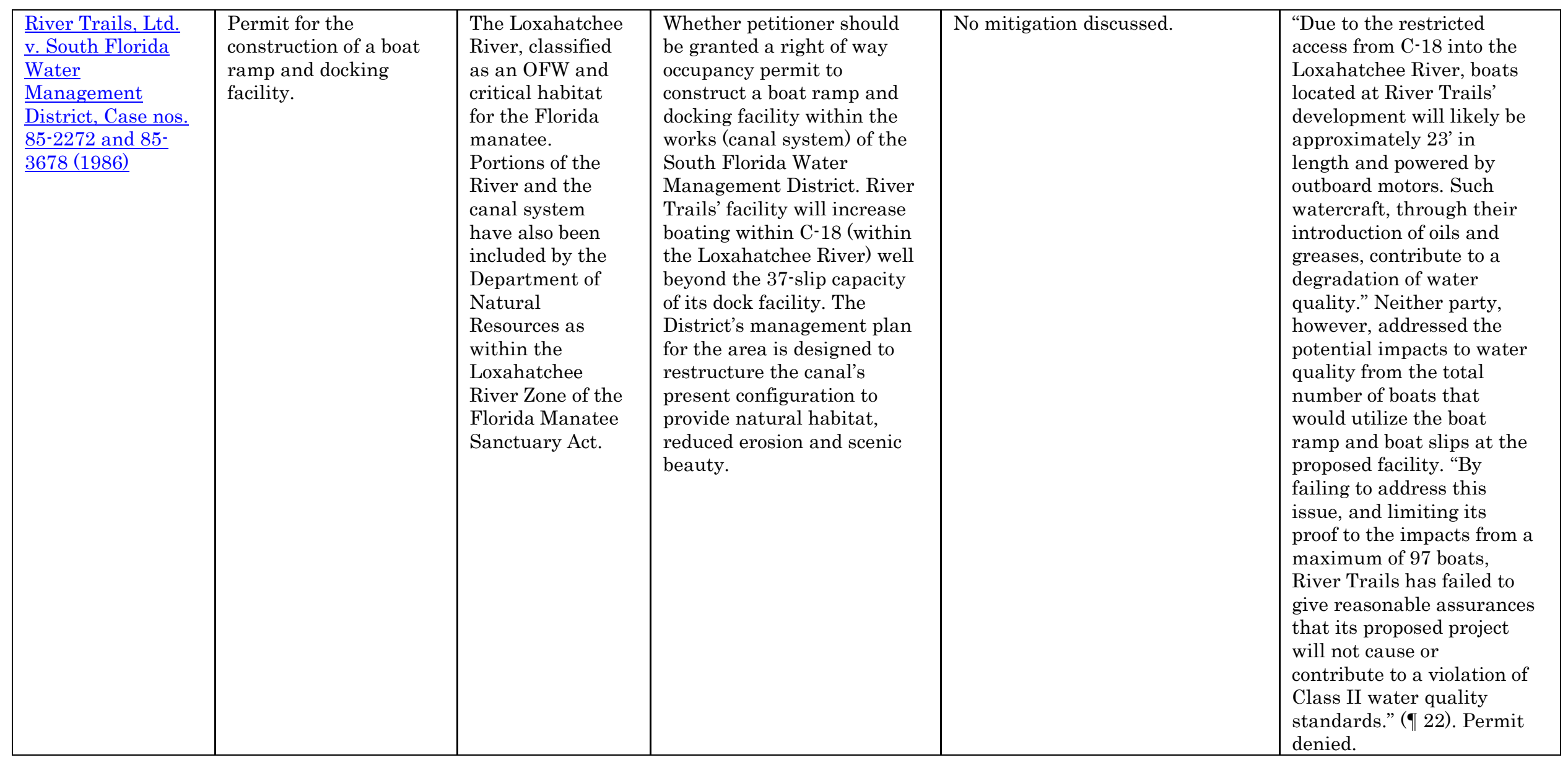




\begin{tabular}{|c|c|c|c|c|c|}
\hline 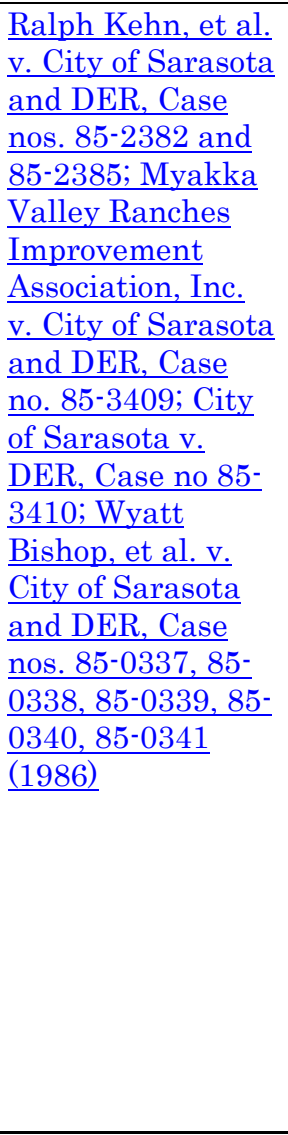 & $\begin{array}{l}\text { Permits for } \\
\text { wastewater treatment } \\
\text { improvements, dredge } \\
\text { and fill, and } \\
\text { exemption to use } \\
\text { wetlands for recycling. }\end{array}$ & $\begin{array}{l}\text { Surface and } \\
\text { groundwater } \\
\text { presently flows } \\
\text { from the } \\
\text { proposed spray } \\
\text { site to the south- } \\
\text { southwest into } \\
\text { Howard Creek, } \\
\text { and to the south- } \\
\text { southeast into } \\
\text { East Ditch, both } \\
\text { Class III waters, } \\
\text { which then } \\
\text { converge and } \\
\text { flow into } \\
\text { Upper Lake } \\
\text { Myakka, a Class } \\
\text { I water and a } \\
\text { OFW. From } \\
\text { Upper Lake } \\
\text { Myakka, water } \\
\text { flows into } \\
\text { Vanderipe } \\
\text { Slough, a class } \\
\text { III water body, } \\
\text { and Lower Lake } \\
\text { Myakka; a Class } \\
\text { I water and OFW } \\
\text { via the Myakka } \\
\text { River. }\end{array}$ & $\begin{array}{l}\text { The city has three } \\
\text { applications involved in this } \\
\text { matter, including: (1) an } \\
\text { application for a permit to } \\
\text { construct wastewater } \\
\text { treatment plant and } \\
\text { disposal system } \\
\text { improvements: (2) an } \\
\text { application for a permit for } \\
\text { dredging and filling for } \\
\text { activities associated with } \\
\text { this project and (3) an } \\
\text { application for a wetlands } \\
\text { exemption to allow the use } \\
\text { of wetlands for water and } \\
\text { wastewater recycling } \\
\text { through the use of a } \\
\text { sprayfield. }\end{array}$ & $\begin{array}{l}\text { Proposed project will preserve } 96 \\
\text { acres of natural wetlands on the } \\
\text { East Ditch and create a total of } \\
196 \text { acres of artificial or } \\
\text { mitigation wetlands. ( } 11 \text { ). }\end{array}$ & $\begin{array}{l}\text { Recommended that the } \\
\text { Department enter a Final } \\
\text { Order denying the City of } \\
\text { Sarasota's Application for } \\
\text { Wetlands Exemption, } \\
\text { Application for } \\
\text { Construction Permit, and } \\
\text { Application for Dredge and } \\
\text { Fill Permit. Since the City } \\
\text { has not demonstrated its } \\
\text { entitlement to a } \\
\text { wetlands exemption, its } \\
\text { efforts to mitigate the } \\
\text { project's adverse effects } \\
\text { with the use of mitigation } \\
\text { wetlands cannot be } \\
\text { pursued, and the } \\
\text { exemption provided in } \S \\
403.918(2) \text { (b), Fla. Stat. } \\
\text { from dredge and fill } \\
\text { criteria and water quality } \\
\text { standards is therefore not } \\
\text { applicable. }\end{array}$ \\
\hline $\begin{array}{l}\text { Friends of Fort } \\
\text { George, Inc., et al. } \\
\text { v. Fairfield } \\
\text { Communities, Inc. } \\
\text { and St. Johns } \\
\text { River Water } \\
\text { Management } \\
\text { District, Case nos. } \\
\begin{array}{l}\text { 35-3537 and } 85^{-} \\
596(1986)\end{array}\end{array}$ & $\begin{array}{l}\text { Permit for surface } \\
\text { water management } \\
\text { system and } \\
\text { Consumptive Use } \\
\text { Permit. }\end{array}$ & $\begin{array}{l}\text { Fort George } \\
\text { Island and } \\
\text { surrounding } \\
\text { surface waters, } \\
\text { which are Class II } \\
\text { and III OFWs. }\end{array}$ & $\begin{array}{l}\text { Friends of Fort George, Inc., } \\
\text { et al., challenge the } \\
\text { District's proposed issuance } \\
\text { of a conceptual approval } \\
\text { with conditions for the } \\
\text { surface water management } \\
\text { system of a development } \\
\text { which includes residential } \\
\text { units, commercial space, } \\
\text { and a } 27 \text {-hole golf course on } \\
\text { Fort George Island. } \\
\text { Fairfield Communities } \\
\text { concedes that even if }\end{array}$ & $\begin{array}{l}\text { "Mitigation will be required for } \\
\text { any disturbance of a small } \\
\text { wetland area on the west side of } \\
\text { the Island which is } \\
\text { approximately } 3 / 4 \text { of an acre in } \\
\text { size." ( } 56 \text { ). Moreover, the } \\
\text { District recommended that } \\
\text { fourteen specific conditions be } \\
\text { placed on the conceptual } \\
\text { approval. }\end{array}$ & $\begin{array}{l}\text { Recommended that the } \\
\text { District issue a conceptual } \\
\text { approval to Fairfield } \\
\text { Communities for the } \\
\text { surface water } \\
\text { management system, as } \\
\text { well as the Consumptive } \\
\text { Use Permit with } \\
\text { conditions as set forth by } \\
\text { the District. This } \\
\text { recommendation was } \\
\text { affirmed and ordered in } \\
\text { the final agency order }\end{array}$ \\
\hline
\end{tabular}




\begin{tabular}{|c|c|c|c|c|c|}
\hline & & & $\begin{array}{l}\text { conceptual approval is } \\
\text { obtained, it will have to } \\
\text { apply for actual } \\
\text { construction, operation or } \\
\text { maintenance permits } \\
\text { pursuant to } \S \S 373.413 \text { and } \\
373.416, \text { Fla. Stat. }\end{array}$ & & $\begin{array}{l}\text { after all exceptions to the } \\
\text { original recommendation } \\
\text { were heard. }\end{array}$ \\
\hline $\begin{array}{l}\text { Boca Grande } \\
\frac{\text { Club, Inc. v. DER, }}{\text { Case no. } 85-3849} \\
\underline{(1986)}\end{array}$ & $\begin{array}{l}\text { Dredge and fill permit } \\
\text { to construct an } \\
\text { additional } 25 \text { boat } \\
\text { slips with a private } \\
\text { docking facility in } \\
\text { conjunction with its } \\
\text { multi-family, } \\
\text { residential } \\
\text { development. Boca } \\
\text { Grande Club currently } \\
\text { operates an existing } \\
\text { 58-slip marina at the } \\
\text { same location. }\end{array}$ & $\begin{array}{l}\text { Project is to be } \\
\text { located in } \\
\text { Gasparilla Sound, } \\
\text { in the Charlotte } \\
\text { Harbor Aquatic } \\
\text { Preserve, a Class } \\
\text { II OFW }\end{array}$ & $\begin{array}{l}\text { Whether Petitioner has } \\
\text { provided reasonable } \\
\text { assurances that the } \\
\text { proposed dredge and } \\
\text { fill project will not lower } \\
\text { ambient water quality in } \\
\text { the Charlotte Harbor } \\
\text { Gasparilla Sound Aquatic } \\
\text { Preserve or violate Class II } \\
\text { water quality standards. } \\
\text { Additionally, it must be } \\
\text { determined whether the } \\
\text { Petitioner has provided } \\
\text { reasonable assurances that } \\
\text { the proposed project is } \\
\text { clearly in the public } \\
\text { interest. }\end{array}$ & $\begin{array}{l}\text { Petitioner failed to propose any } \\
\text { measures designed to mitigate } \\
\text { the adverse effects that may be } \\
\text { caused by the project. The } \\
\text { biological communities or } \\
\text { "fouling organisms" which may } \\
\text { attach to the proposed dock } \\
\text { pilings will not constitute } \\
\text { mitigation for the likely loss of } \\
\text { the seagrass habitat. The fouling } \\
\text { communities do not provide } \\
\text { significant habitat for marine } \\
\text { organisms or detrital production } \\
\text { for the higher forms of marine } \\
\text { organisms such as fish. }\end{array}$ & $\begin{array}{l}\text { Petitioner failed to provide } \\
\text { reasonable assurances } \\
\text { that the project will not } \\
\text { lower ambient water } \\
\text { quality in the OFWs nor } \\
\text { did it provide reasonable } \\
\text { assurances that the project } \\
\text { will be clearly in the public } \\
\text { interest. The adverse } \\
\text { effects to marine } \\
\text { productivity, conservation } \\
\text { of fish and wildlife and } \\
\text { their habitats, and the } \\
\text { other ill effects which will } \\
\text { result from the advent of } \\
\text { this project outweigh any } \\
\text { benefits inuring to the } \\
\text { public and to the local } \\
\text { community from the } \\
\text { project. ( } ₫ \text { 44). }\end{array}$ \\
\hline $\begin{array}{l}\text { Sante Fe Lake } \\
\text { Dwellers } \\
\text { Association, Inc. } \\
\text { v. DER and Sante } \\
\text { Fe Pass, Inc., } \\
\text { Case no. 85-4446 } \\
\underline{(1986)}\end{array}$ & $\begin{array}{l}\text { Permit to construct } \\
\text { sewage treatment } \\
\text { plant to treat sewage } \\
\text { generated by staff and } \\
\text { diners at a } 150^{-} \text {seat } \\
\text { restaurant and by } \\
\text { inhabitants of } 150 \\
\text { lodge or motel rooms, } \\
\text { comprising } 100 \\
\text { distinct units. The } \\
\text { applicant assumed } \\
\text { that } 150 \text { rooms could } \\
\text { house } 275 \text { persons } \\
\text { who would generate } \\
75 \text { gallons of sewage a } \\
\text { day and that a } 150^{-}\end{array}$ & $\begin{array}{l}\text { Sante Fe Lake } \\
\text { and Little Sante } \\
\text { Fe Lake are } \\
\text { OFWs. }\end{array}$ & $\begin{array}{l}\text { Whether SFP's revised } \\
\text { application for a permit to } \\
\text { construct a sewage } \\
\text { treatment plant with } \\
\text { percolation ponds should be } \\
\text { granted or should be denied } \\
\text { for failure of SFP to give } \\
\text { reasonable assurances that } \\
\text { the plant will not cause } \\
\text { pollution significantly } \\
\text { degrading the waters of } \\
\text { Gator Cove. Evidence } \\
\text { showed that effluent from } \\
\text { the proposed plant would } \\
\text { enter OFWs under overflow } \\
\text { conditions and there was a }\end{array}$ & No mitigation discussed. & $\begin{array}{l}\text { It is likely that the } \\
\text { proposed water treatment } \\
\text { plant would indeed result } \\
\text { in effluent seeping to the } \\
\text { surface of the ground down } \\
\text { slope from the percolation } \\
\text { ponds and flowing } \\
\text { overland to Gator Cove, } \\
\text { ultimately inducing } \\
\text { eutrophication of the Cove, } \\
\text { in violation of the legal } \\
\text { prohibition against } \\
\text { significant degradation of } \\
\text { waters designated OFW. } \\
\text { ( } ₫ \text { 67). Permit denied. }\end{array}$ \\
\hline
\end{tabular}




\begin{tabular}{|c|c|c|c|c|c|}
\hline & $\begin{array}{l}\text { seat restaurant would } \\
\text { generate } 50 \text { gallons of } \\
\text { sewage per seat per } \\
\text { day. Full occupancy is } \\
\text { projected to engender } \\
28,125 \text { gallons of } \\
\text { sewage per day. }(\mathbb{q} \text { 4). }\end{array}$ & & $\begin{array}{l}\text { likelihood that effluent } \\
\text { would enter under normal } \\
\text { weather conditions, } \\
\text { therefore r. 17-4.242, Fla. } \\
\text { Admin. Code, also applies. } \\
\text { (ף 57). }\end{array}$ & & \\
\hline $\begin{array}{l}\text { Leisey Shellpit, } \\
\text { Inc. v. DER and } \\
\text { Manasota-88, } \\
\text { Inc., et al., Case } \\
\text { nos. 86-0568 and } \\
\underline{86-0569(1986)}\end{array}$ & $\begin{array}{l}\text { Variance and a dredge } \\
\text { and fill permit to } \\
\text { construct and operate } \\
\text { a 870-boat marina. } \\
\text { Petitioner proposes to } \\
\text { develop 55 acres } \\
\text { located on a 16-acre } \\
\text { lake adjacent to the } \\
\text { waters of Little } \\
\text { Cockroach Bay in } \\
\text { Hillsborough County. } \\
\text { Leisey Shellpit } \\
\text { proposes to widen and } \\
\text { deepen existing canals } \\
\text { and mosquito ditches } \\
\text { to provide access from } \\
\text { the marina to } \\
\text { Cockroach Bay and } \\
\text { the open waters of } \\
\text { Tampa Bay. The } \\
\text { developer also plans a } \\
\text { flushing channel, a } \\
\text { 250-seat restaurant, a } \\
24 \text {-unit hotel or motel, } \\
\text { a museum, fueling } \\
\text { facilities with upland } \\
\text { gas storage, an 8-boat } \\
\text { ramp launching area, } \\
\text { a convenience store, a } \\
\text { boat repair facility, a } \\
\text { dockmaster's office } \\
\text { and } 688 \text { parking } \\
\text { spaces. A 114-unit } \\
\text { apartment complex } \\
\text { and } 23 \text { single-family } \\
\text { residential lots are }\end{array}$ & $\begin{array}{l}\text { Cockroach Bay } \\
\text { Aquatic Preserve } \\
\text { - Class II OFW } \\
\text { approved for } \\
\text { shellfish } \\
\text { harvesting. The } \\
\text { proposed marina } \\
\text { would be located } \\
\text { in a lake created } \\
\text { by shell mining, } \\
\text { which is not a } \\
\text { state water at this } \\
\text { time. It will, } \\
\text { however, become a } \\
\text { state water when } \\
\text { connected to other } \\
\text { state waters by } \\
\text { the proposed } \\
\text { access channels } \\
\text { and flushing } \\
\text { channel. Upon } \\
\text { connection, it } \\
\text { would be classified } \\
\text { as a Class III } \\
\text { water body. ( } ₫ \text { 3). }\end{array}$ & $\begin{array}{l}\text { Whether Leisey Shellpit, } \\
\text { Inc. is entitled to a variance } \\
\text { of Rule 17-4.28(8)(a), Fla. } \\
\text { Admin. Code (renumbered } \\
\text { as } 17-4.280(8) \text { (a) effective } \\
\text { November 20,1986) in } \\
\text { order to apply for a dredge } \\
\text { and fill permit for its } \\
\text { project known as Mangrove } \\
\text { Bay Marina located in } \\
\text { Hillsborough County; and, } \\
\text { if so, whether petitioner is } \\
\text { in fact entitled to a dredge } \\
\text { and fill permit from the } \\
\text { DER. }\end{array}$ & $\begin{array}{l}\text { Petitioner offers mitigation plans } \\
\text { with regard to seagrasses, } \\
\text { mangroves, stormwater, } \\
\text { agricultural runoff and sewage } \\
\text { treatment. Petitioner argued that } \\
\text { this mitigation, along with the } \\
\text { provision of a secure and well- } \\
\text { policed facility, will have a } \\
\text { beneficial effect upon public } \\
\text { health, safety and welfare and } \\
\text { will conserve fish and wildlife } \\
\text { and their habitat. It is also urged } \\
\text { that its well-marked and } \\
\text { maintained channels will } \\
\text { improve navigation and not } \\
\text { contribute to harmful shoaling or } \\
\text { erosion and will provide for an } \\
\text { adequate flow of water." }\end{array}$ & $\begin{array}{l}\text { The Cockroach Bay and } \\
\text { Little Cockroach Bay areas } \\
\text { are relatively undisturbed } \\
\text { by development. The area } \\
\text { is important as a research } \\
\text { area and as a nursery area } \\
\text { for juvenile fish and } \\
\text { shellfish. "Even if } \\
\text { petitioner were entitled to } \\
\text { a variance, it has not } \\
\text { provided reasonable } \\
\text { assurances that the short } \\
\text { and long term effects of } \\
\text { the proposed activities will } \\
\text { not violate water quality } \\
\text { standards and public } \\
\text { interest requirements so } \\
\text { as to be entitled to a } \\
\text { dredge and fill permit." ( } \\
\text { 37). "The petitioner's } \\
\text { mitigation plans for the } \\
\text { removal of seagrasses and } \\
\text { mangroves is likewise } \\
\text { unacceptable." ( } ₫ 42 \text { ) } \\
\text { "While the project may } \\
\text { provide some advantages } \\
\text { with regard to recreation } \\
\text { and public safety, its } \\
\text { adverse effects upon fish, } \\
\text { wildlife, harmful erosion } \\
\text { and shoaling, marine } \\
\text { productivity and the } \\
\text { present condition and } \\
\text { value of the functions } \\
\text { being performed in the } \\
\text { area are contrary to the }\end{array}$ \\
\hline
\end{tabular}




\begin{tabular}{|c|c|c|c|c|c|}
\hline & $\begin{array}{l}\text { also planned on other } \\
\text { lakes nearby, which } \\
\text { would require, } \\
\text { stormwater and } \\
\text { agricultural runoff } \\
\text { systems and a sewage } \\
\text { treatment plant. }\end{array}$ & & & & $\begin{array}{l}\text { public interest. Petitioner } \\
\text { has failed to demonstrate } \\
\text { any overriding public } \\
\text { interest that would } \\
\text { outweigh these } \\
\text { considerations." ( } ₫ 47) . \\
\text { Permit denied. }\end{array}$ \\
\hline $\begin{array}{l}\text { Sante Fe Pass, Inc. } \\
\text { v. DER and Sante } \\
\text { Fe Lake Dwellers } \\
\underline{\text { Association, Inc., }} \\
\underline{\text { Case no. 86-1445 }} \\
\underline{(1986)}\end{array}$ & $\begin{array}{l}\text { Permit to construct } \\
\text { stormwater } \\
\text { management system to } \\
\text { serve all of } \\
\text { Phase II of the Santa } \\
\text { Fe Pass development, } \\
\text { which consists of } \\
\text { approximately } 20 \text { acres. } \\
\text { Phase II contains an } \\
\text { access road, tennis and } \\
\text { racquet ball facilities, } \\
50 \text { cabanas or villas } \\
\text { (constructed as } \\
\text { duplexes) which will } \\
\text { serve as overnight } \\
\text { accommodations for a } \\
\text { private club, a } \\
\text { restaurant and other } \\
\text { common buildings for } \\
\text { recreational use, and a } \\
\text { dry boat storage } \\
\text { facility. }\end{array}$ & $\begin{array}{l}\text { Sante Fe Lake } \\
\text { and Little Sante } \\
\text { Fe Lake are } \\
\text { OFWs. }\end{array}$ & $\begin{array}{l}\text { Whether Petitioner is } \\
\text { entitled to the issuance of } \\
\text { an individual construction } \\
\text { permit for a proposed } \\
\text { stormwater management } \\
\text { system intended to serve } \\
\text { Phase II of the Petitioner's } \\
\text { land development project. }\end{array}$ & $\begin{array}{l}\text { No mitigation discussed. However, } \\
\text { "every aspect of the proposed } \\
\text { stormwater management system } \\
\text { exceeds the Department's design } \\
\text { and performance criteria, and the } \\
\text { evidence clearly establishes that } \\
\text { the facilities comply with the best } \\
\text { management practices and } \\
\text { performance standards outlined" } \\
\text { by the Department. Moreover, "the } \\
\text { design for this system includes } \\
\text { ample considerations for sediment, } \\
\text { turbidity, and erosion controls } \\
\text { during the construction phase of } \\
\text { this project, and the operation and } \\
\text { maintenance schedule will ensure } \\
\text { continuing compliance with } \\
\text { Department criteria" ( } 16 \text {. }\end{array}$ & $\begin{array}{l}\text { Because applicant provided } \\
\text { additional storage as } \\
\text { specified in } \S 17-25.025(9) \text {, } \\
\text { Fla. Stat., it has } \\
\text { presumptively afforded the } \\
\text { OFWs additional protection. } \\
\text { In addition, the special } \\
\text { protections afforded OFWs } \\
\text { by } \S 17-4.242(1) \text { have been } \\
\text { satisfied. "The applicant has } \\
\text { provided competent and } \\
\text { substantial evidence by } \\
\text { comparing the predicted } \\
\text { concentrations of the waters } \\
\text { discharged with ambient } \\
\text { water quality that there will } \\
\text { be no degradation of the } \\
\text { receiving waters. } \\
\text { Furthermore, the public } \\
\text { interest criteria ... are } \\
\text { inapplicable to this } \\
\text { application since the } \\
\text { proposal does not involve } \\
\text { the discharge of waste into } \\
\text { an OFW." ( } ₫ 12 \text { ). }\end{array}$ \\
\hline $\begin{array}{l}\text { Richard O'Malley v. } \\
\text { DER and Meister } \\
\text { Developments, } \\
\underline{\text { Case no. 86-4747 }} \\
\underline{(1987)}\end{array}$ & $\begin{array}{l}\text { Dredge and fill permit } \\
\text { issued to Meister } \\
\text { Developments for a } \\
\text { revetment with } \\
\text { riprap. The project's } \\
\text { purpose was to combat } \\
\text { erosion that was } \\
\text { threatening to } \\
\text { undermine a } \\
\text { condominium complex. } \\
\text { At the time of the }\end{array}$ & $\begin{array}{l}\text { The revetment is } \\
\text { located near the } \\
\text { northerly coast of } \\
\text { Pine Island in } \\
\text { Charlotte Harbor. } \\
\text { The property } \\
\text { fronts on Pine } \\
\text { Island Sound, a } \\
\text { Class II OFW. }\end{array}$ & $\begin{array}{l}\text { Whether DER should issue } \\
\text { a dredge and fill permit to } \\
\text { construct a } 205 \text { linear feet } \\
\text { interlocking block } \\
\text { revetment with riprap toe } \\
\text { stones and deposit } \\
\text { approximately } 296 \text { cubic } \\
\text { yards of fill } 196 \text { feet } \\
\text { waterward of mean high } \\
\text { water in Charlotte Harbor. } \\
\text { Challengers alleged that }\end{array}$ & $\begin{array}{l}\text { No mitigation discussed. However, } \\
\text { Meister agreed to grant a } \\
\text { conservation easement to DNR } \\
\text { and an easement to allow the } \\
\text { public access across the property } \\
\text { seaward of the residential } \\
\text { development. Additionally Meister } \\
\text { conferred with the OFW Group to } \\
\text { obtain their acquiescence to the } \\
\text { project and agreed to provide } \\
\text { navigational aids to mark the Jug }\end{array}$ & $\begin{array}{l}\text { The water quality issues } \\
\text { were limited to those due to } \\
\text { or caused by erosion and the } \\
\text { public interest issues only } \\
\text { involved the adverse effect } \\
\text { on neighboring property. } \\
\text { The effect of the project on } \\
\text { other property should be } \\
\text { considered, but the weight } \\
\text { of the evidence suggests the } \\
\text { revetment is not the }\end{array}$ \\
\hline
\end{tabular}




\begin{tabular}{|c|c|c|c|c|c|}
\hline & $\begin{array}{l}\text { challenge, the permit } \\
\text { had already been } \\
\text { issued and the project } \\
\text { completed. }\end{array}$ & & $\begin{array}{l}\text { the project is causing severe } \\
\text { erosion; does not meet } \\
\text { water quality standards; is } \\
\text { not in the public interest; } \\
\text { and will have secondary } \\
\text { and cumulative adverse } \\
\text { impacts. }\end{array}$ & $\begin{array}{l}\text { Creek Channel. Additionally, "to } \\
\text { enhance the public interest } \\
\text { concept the applicant agreed to } \\
\text { place toe stones at the foot of the } \\
\text { revetment and plant mangroves." } \\
\text { (ब 6). }\end{array}$ & $\begin{array}{l}\text { proximate cause or a } \\
\text { contributing factor of beach } \\
\text { erosion at O'Malley's } \\
\text { property. Project, with the } \\
\text { conditions imposed, is in the } \\
\text { public interest. The permit } \\
\text { was rightfully granted. }\end{array}$ \\
\hline 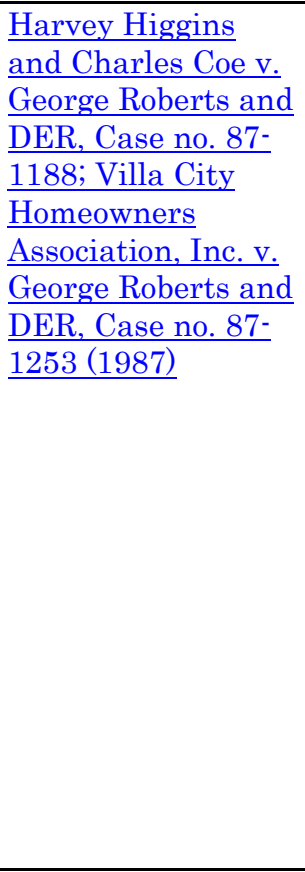 & $\begin{array}{l}\text { Permit to construct a } \\
\text { water ski course. }\end{array}$ & $\begin{array}{l}\text { Lake Emma, a } \\
\text { 175-acre lake } \\
\text { located within the } \\
\text { Palatlakaha River } \\
\text { Basin. Lake } \\
\text { Emma is the } \\
\text { northernmost lake } \\
\text { in the Clermont } \\
\text { Chain of Lakes, an } \\
\text { OFW. The course } \\
\text { itself will take up } \\
\text { only approx. } 1.39 \\
\text { acres, however, } \\
\text { with the } \\
\text { turnarounds at } \\
\text { each end and an } \\
\text { additional } 75 \text { feet } \\
\text { of width to } \\
\text { complete the } \\
\text { course's circuit, } \\
4.82 \text { acres of lake } \\
\text { surface would be } \\
\text { affected. }\end{array}$ & $\begin{array}{l}\text { Whether a permit/water } \\
\text { quality certification should } \\
\text { be granted to construct a } \\
\text { permanent slalom water ski } \\
\text { course } 800 \text { feet long and } 75 \\
\text { feet wide in Lake Emma. } \\
\text { "Harvey Higgins and } \\
\text { Charles Coe (Case No. 87- } \\
\text { 1188) and the Villa City } \\
\text { Home Owners Association, } \\
\text { Inc. (Case No. } 87-1253 \text { ) } \\
\text { timely filed petitions for a } \\
\text { formal administrative } \\
\text { proceeding to challenge the } \\
\text { application." ( } ₫ 2 \text { ). }\end{array}$ & $\begin{array}{l}\text { No mitigation was discussed. The } \\
\text { project would have the greatest } \\
\text { negative impact on the property of } \\
\text { other Lake Emma shore owners } \\
\text { and residents. However, Roberts } \\
\text { proposes to make the ski course } \\
\text { open to the public. "Ironically, the } \\
\text { more the ski course is used by the } \\
\text { public, the more that use will } \\
\text { clash and interfere with existing } \\
\text { use of the lake." ( }(22) \text {. }\end{array}$ & $\begin{array}{l}\text { Fourteen residents along } \\
\text { the shore of Lake Emma } \\
\text { opposed the project and no } \\
\text { public sentiment in favor of } \\
\text { the ski course was } \\
\text { expressed at the hearing. ( } ₫ \\
\text { 13). "It is recommended that } \\
\text { the DER enter a final order } \\
\text { denying the application of } \\
\text { George A. Roberts for a } \\
\text { permit for a permanent } \\
\text { slalom water ski course on } \\
\text { Lake Emma." (RO: pg. } 7 \text { ). } \\
\text { "It cannot be found or } \\
\text { concluded that the applicant } \\
\text { has provided "reasonable } \\
\text { assurance that the project } \\
\text { will be clearly in the public } \\
\text { interest." ( } ₫ 28 \text { ). }\end{array}$ \\
\hline $\begin{array}{l}\text { James and Regina } \\
\text { Williams and } \\
\text { Charles Causey v. } \\
\text { Charles and Julia } \\
\text { Moeller and DER, } \\
\text { Case no. 87-5392 } \\
\underline{(1988)}\end{array}$ & $\begin{array}{l}\text { Dredge and fill permit } \\
\text { to widen an existing } \\
\text { dock to four feet wide. } \\
\text { No dredging or filling is } \\
\text { necessary to add } \\
\text { plankings to the } \\
\text { existing dock. The } \\
\text { widening of the dock is } \\
\text { to alleviate safety } \\
\text { problems associated } \\
\text { with the narrow dock. } \\
\text { Mrs. Moeller's } \\
\text { (Respondent) mother, }\end{array}$ & $\begin{array}{l}\text { Property located } \\
\text { in Islamorada, } \\
\text { Monroe County, } \\
\text { located on Florida } \\
\text { Bay, an OFW. }\end{array}$ & $\begin{array}{l}\text { Whether or not Moeller is } \\
\text { entitled to the issuance of a } \\
\text { dredge and fill permit to } \\
\text { widen and existing dock } \\
\text { from two to four feet wide. }\end{array}$ & $\begin{array}{l}\text { A number of factors stand to } \\
\text { mitigate any adverse impact } \\
\text { caused by increased shading } \\
\text { from the wider dock, including } \\
\text { the site's high dissolved oxygen } \\
\text { content, the movement of the } \\
\text { dock's shadow with the passage } \\
\text { of the sun and the seasons, and } \\
\text { ability of seagrasses to adapt to } \\
\text { certain degrees of shading. DER } \\
\text { also imposed conditions, } \\
\text { including a prohibition on } \\
\text { liveaboards, fueling facilities, }\end{array}$ & $\begin{array}{l}\text { "The only certain } \\
\text { environmental impact } \\
\text { associated with the } \\
\text { widening of the existing } \\
\text { dock is the additional } \\
\text { shading of the grassbeds } \\
\text { that lie under the dock." ( } \\
\text { 13). "The applicants } \\
\text { clearly demonstrated both } \\
\text { reasonable assurances } \\
\text { that the water quality } \\
\text { standards will not be } \\
\text { violated and that the }\end{array}$ \\
\hline
\end{tabular}




\begin{tabular}{|c|c|c|c|c|c|}
\hline & $\begin{array}{l}\text { confined to a } \\
\text { wheelchair, is not able } \\
\text { to use the existing dock } \\
\text { at all. }\end{array}$ & & & $\begin{array}{l}\text { boat and motor maintenance, and } \\
\text { hull scraping or painting. Also, } \\
\text { the original dock permit was } \\
\text { conditioned on the grant of a } \\
\text { conservation easement } \\
\text { prohibiting any other docking } \\
\text { structures from being built upon } \\
\text { their shoreline. }\end{array}$ & $\begin{array}{l}\text { project is clearly in the } \\
\text { public interest. The } \\
\text { permit, as appropriately } \\
\text { conditioned, and } \\
\text { dependent upon the } \\
\text { conservation easement, } \\
\text { should be granted.” ( } \$ 42) \text {. }\end{array}$ \\
\hline $\begin{array}{l}\text { Vincent Drost v. } \\
\text { DER, Case no. 87- } \\
\underline{4067(1988)}\end{array}$ & $\begin{array}{l}\text { Permit to construct } \\
\text { vertical seawalls } \\
\text { bulkheads and patios. } \\
\text { Florida law prohibits } \\
\text { the construction of } \\
\text { vertical seawalls } \\
\text { unless vertical } \\
\text { seawalls already } \\
\text { occupy the canal in } \\
\text { whole or in part. } \\
\text { Because the FDEP } \\
\text { exempted most of the } \\
\text { project, only } 8,000 \\
\text { liner feet of shoreline } \\
\text { is in issue. }\end{array}$ & $\begin{array}{l}\text { Bow Channel and } \\
\text { Cudjoe Bay - } \\
\text { Class III OFWs }\end{array}$ & $\begin{array}{l}\text { Whether petitioner's } \\
\text { application to construct } \\
\text { vertical bulkheads and patios } \\
\text { on top of existing caprock } \\
\text { within the manmade canals } \\
\text { of Cudjoe Gardens should be } \\
\text { approved. DER issued a } \\
\text { notice to deny based on } \S \\
403.918(5)(b) \text {, Fla. Stat., } \\
\text { which "prohibits the } \\
\text { installation of vertical } \\
\text { seawalls in lagoons unless } \\
\text { within existing canals that } \\
\text { are currently occupied in } \\
\text { whole or in part by vertical } \\
\text { seawalls," and } \S 403.918(2) \\
\text { which prohibits such } \\
\text { activities in OFWs unless the } \\
\text { project is clearly in the public } \\
\text { interest. }\end{array}$ & $\begin{array}{l}\text { No mitigation was discussed to } \\
\text { offset the adverse impacts the } \\
\text { seawalls would have on fish and } \\
\text { wildlife, their habitats, and } \\
\text { marine productivity. "The } \\
\text { destruction of the intertidal } \\
\text { vegetation where the seawalls } \\
\text { would be replaced and the total } \\
\text { isolation of the remaining wetland } \\
\text { vegetation located landward of the } \\
\text { seawalls, would prevent those } \\
\text { species from providing their } \\
\text { traditional wetland values." ( } ₫ 15) \text {. }\end{array}$ & $\begin{array}{l}\text { "Upon consideration of the } \\
\text { criteria set forth in } \S \\
403.918(2) \text {, Fla. Stat., it is } \\
\text { concluded that the } \\
\text { petitioner has failed to } \\
\text { meet the burden of proof" } \\
\text { to show that the project is } \\
\text { clearly in the public } \\
\text { interest. ( } 932) \text {.In fact, } \\
\text { the weight of the evidence } \\
\text { fails to show that the } \\
\text { project is not contrary to } \\
\text { the public interest." ( } ₫ 32) \text {. }\end{array}$ \\
\hline $\begin{array}{l}\text { Sunland Estates, } \\
\text { Inc. v. DER and } \\
\text { The Izaak Walton } \\
\text { League, Mangrove } \\
\underline{\text { Chapter, Case no. }} \\
\underline{88-1813(1989)}\end{array}$ & $\begin{array}{l}\text { Permit to remove a } \\
\text { canal plug and dredge } \\
\text { an access channel. } \\
\text { Petitioner's property } \\
\text { in Key Largo contains } \\
\text { a dead-end canal and } \\
\text { a plug at the mouth of } \\
\text { the canal prevents } \\
\text { boat traffic from } \\
\text { entering and exiting. } \\
\text { Petitioner proposes to } \\
\text { remove the plug and } \\
\text { shallow the canal to a } \\
\text { uniform depth of - } 10 \\
\text { feet and two years }\end{array}$ & $\begin{array}{l}\text { Florida Keys } \\
\text { Special Waters } \\
\text { (Key Largo)- } \\
\text { Class III OFWs. }\end{array}$ & $\begin{array}{l}\text { Whether Petitioner's } \\
\text { application for a dredge and } \\
\text { fill permit should be } \\
\text { approved. }\end{array}$ & $\begin{array}{l}\text { Sunland Estates contends it is } \\
\text { willing to install a curb around the } \\
\text { existing canal to prevent runoff } \\
\text { into the canal, but no evidence was } \\
\text { offered to show that such a result } \\
\text { would in fact be likely. Further, } \\
\text { even if such a curb could be } \\
\text { constructed, it would not prevent } \\
\text { surface runoff or have any effect } \\
\text { on pollutants and nutrients } \\
\text { discharging into the canal directly } \\
\text { or through the adjacent ground. } \\
\text { Similarly, Petitioner's contention } \\
\text { that the adverse impacts would be } \\
\text { reduced by the mechanical }\end{array}$ & $\begin{array}{l}\text { Given the additional } \\
\text { discharge of pollutants and } \\
\text { nutrients expected and the } \\
\text { fact that the area is not } \\
\text { expected to revegetate, the } \\
\text { adverse effects of the } \\
\text { project will not be offset. } \\
\text { On balance, the proposed } \\
\text { project fails to be clearly in } \\
\text { the public interest, and in } \\
\text { fact would be detrimental } \\
\text { to the public interest. The } \\
\text { increased pollution } \\
\text { expected from the planned } \\
\text { development by way of }\end{array}$ \\
\hline
\end{tabular}




\begin{tabular}{|c|c|c|c|c|c|}
\hline & $\begin{array}{l}\text { later to a uniform } \\
\text { depth of }-6 \text { feet. } \\
\text { Petitioner further } \\
\text { proposes to dredge an } \\
\text { access channel from } \\
\text { the mouth of the canal } \\
\text { to an existing channel. }\end{array}$ & & & $\begin{array}{l}\text { planting of seagrass and algae in } \\
\text { the dredged channel is unlikely } \\
\text { since the evidence clearly reveals } \\
\text { that such replanting efforts have } \\
\text { met with only very minimal } \\
\text { success, and such efforts have } \\
\text { been unsuccessful when attempted } \\
\text { in an adjoining channel.” }\end{array}$ & $\begin{array}{l}\text { septic tank discharges, } \\
\text { boats and boat engines, } \\
\text { lawn fertilizers, and } \\
\text { stormwater run-off from } \\
\text { paved areas will degrade } \\
\text { the adjacent OFWs. } \\
\text { Recommended denial of } \\
\text { permit. }\end{array}$ \\
\hline $\begin{array}{l}\text { Chipola Basin } \\
\text { Protective Group, } \\
\text { Inc. and Florida } \\
\text { Chapter Sierra } \\
\text { Club v. DER and } \\
\text { Developers } \\
\text { Diversified, Case } \\
\text { no. 88-3355 (1988) } \\
\end{array}$ & $\begin{array}{l}\text { Dredge and fill permit } \\
\text { to fill approximately } \\
0.83 \text { acres of wetlands } \\
\text { and for construction } \\
\text { and operation of a } \\
\text { shopping center. }\end{array}$ & $\begin{array}{l}\text { Project site } \\
\text { includes an } \\
\text { unnamed } \\
\text { watercourse } \\
\text { (referred to as the } \\
\text { "north/south } \\
\text { watercourse") } \\
\text { which exits the } \\
\text { site under U.S } \\
\text { Highway } 90 \text { and } \\
\text { connects to a } \\
\text { floodplain to the } \\
\text { Chipola River, an } \\
\text { OFW, which is } \\
\text { about one mile } \\
\text { away. The } \\
\text { watercourses on } \\
\text { the actual project } \\
\text { site are not OFWs } \\
\text { because they are } \\
\text { not specifically } \\
\text { named in the } \\
\text { Florida } \\
\text { Administrative } \\
\text { Code. }\end{array}$ & $\begin{array}{l}\text { Whether DER should issue a } \\
\text { dredge and fill permit/ water } \\
\text { quality certification to } \\
\text { Developers Diversified to } \\
\text { construct the Crossroads } \\
\text { Shopping Center. Other } \\
\text { issues involved include } \\
\text { whether the unnamed } \\
\text { jurisdictional watercourses } \\
\text { on the project site are } \\
\text { OFWs and whether } \\
\text { Developers Diversified has } \\
\text { provided "reasonable } \\
\text { assurances" such that the } \\
\text { permit should be issued. }\end{array}$ & $\begin{array}{l}\text { The project was modified to reduce } \\
\text { impact to the wetlands. The } \\
\text { stormwater treatment system was } \\
\text { also modified to alleviate DER's } \\
\text { water quality concerns. } \\
\text { Additionally DER imposed a } \\
\text { number of permitting conditions. } \\
\text { "The project without mitigation } \\
\text { would be contrary to the public } \\
\text { interest because of the overall loss } \\
\text { of } 0.83 \text { acres of wetlands, including } \\
\text { approximately 0.4 acres of good } \\
\text { quality seepage slope streams in } \\
\text { the north and west areas of the } \\
\text { project." This permanent loss } \\
\text { violates } \& 403.918(2)(a)(2) \\
\text { concerning effects on the } \\
\text { conservation of fish and wildlife } \\
\text { and their habitats. "This is } \\
\text { especially important in view of the } \\
\text { fact that the seepage slope } \\
\text { systems are subject to adverse } \\
\text { impacts from development which } \\
\text { are not under the jurisdiction of } \\
\text { the [DER]. Although the loss of } \\
\text { these small wetlands alone would } \\
\text { not greatly impact the existence of } \\
\text { seepage slope systems in the } \\
\text { region, the impact of the loss must } \\
\text { be considered in light of the } \\
\text { previous seepage slope systems } \\
\text { lost in conjunction with the } \\
\text { Merrits Mill Pond dam.” ( } ₫ 62 \text { ). }\end{array}$ & $\begin{array}{l}\text { The watercourses on site } \\
\text { are not OFW or tributaries } \\
\text { to the Chipola River, } \\
\text { because they are not } \\
\text { specifically listed as such in } \\
\text { r. 17- 3.041, Fla. Admin. } \\
\text { Code. "Where the } \\
\text { Department intends to } \\
\text { include specific tributaries, } \\
\text { they are expressly } \\
\text { designated as part of the } \\
\text { related river's OFW } \\
\text { designation. The express } \\
\text { language of r. 17-3.041, } \\
\text { clearly indicates that any } \\
\text { tributaries intended to be so } \\
\text { designated are listed in the } \\
\text { rule." ( } ₫ \text { 60). "Developers } \\
\text { Diversified has provided } \\
\text { reasonable assurances that } \\
\text { the proposed project will not } \\
\text { violate water quality } \\
\text { standards." ( } ₫ \text { 61). "The } \\
\text { preponderance of the } \\
\text { evidence indicates that the } \\
\text { project with the proposed } \\
\text { mitigation is not contrary to } \\
\text { the public interest." ( } ₫ \text { 63). }\end{array}$ \\
\hline
\end{tabular}




\begin{tabular}{|c|c|c|c|c|c|}
\hline 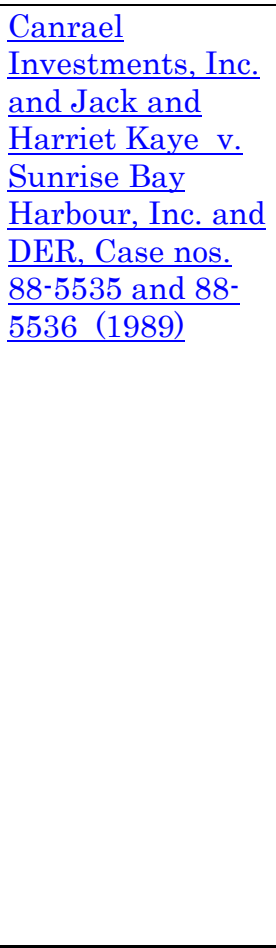 & $\begin{array}{l}\text { Fill permit to } \\
\text { construct a 33-slip } \\
\text { marina with four } \\
\text { sections of dock } \\
\text { facilities to } \\
\text { accommodate yachts } \\
70 \text { feet in length or } \\
\text { longer. }\end{array}$ & $\begin{array}{l}\text { Proposed marina } \\
\text { would be located } \\
\text { on Coral Bay, } \\
\text { which opens onto } \\
\text { the Intracoastal } \\
\text { Waterway at the } \\
\text { Sunrise Boulevard } \\
\text { Bridge. Coral Bay } \\
\text { a Class III OFW. }\end{array}$ & $\begin{array}{l}\text { Whether Sunrise is entitled } \\
\text { to the permit to construct the } \\
\text { proposed marina. Tidal } \\
\text { flushing in Coral Bay is } \\
\text { sufficient to remove } \\
\text { incidental levels of } \\
\text { discharged pollutants, so the } \\
\text { marina will not have a } \\
\text { significant impact on water } \\
\text { quality. }\end{array}$ & $\begin{array}{l}\text { No mitigation was discussed. } \\
\text { However, a number of birds feed } \\
\text { and rest in the area. "The docks } \\
\text { are likely to displace the birds' } \\
\text { direct access to feeding areas but } \\
\text { it is anticipated that the riprap } \\
\text { will increase the surface areas } \\
\text { available for organism } \\
\text { development and thereby enhance } \\
\text { the environment for fishes." ( } ₫ 13) \text {. }\end{array}$ & $\begin{array}{l}\text { Sunrise has established that } \\
\text { the proposed marina will } \\
\text { not violate water quality } \\
\text { standards, and that the } \\
\text { project is not contrary to the } \\
\text { public interest. The specific } \\
\text { conditions required for this } \\
\text { project adequately offset } \\
\text { any adverse affect } \\
\text { anticipated to result from } \\
\text { this project. ( } ₫ \text { 21). Also, } \\
\text { "the Kayes have not } \\
\text { presented any facts which } \\
\text { refute this evidence. The } \\
\text { personal desire to have the } \\
\text { property remain } \\
\text { undeveloped and available } \\
\text { for the general public's use } \\
\text { does not establish that the } \\
\text { proposed project will } \\
\text { adversely affect the water } \\
\text { quality of Coral Bay or that } \\
\text { the proposed project is } \\
\text { contrary to the public } \\
\text { interest." ( } 9 \text { 27). }\end{array}$ \\
\hline 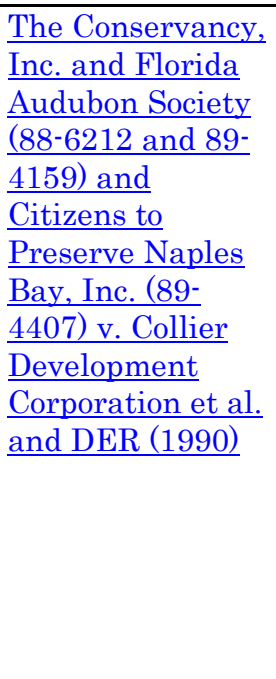 & $\begin{array}{l}\text { Dredge and fill permit } \\
\text { for a development } \\
\text { project. DER authorized } \\
\text { a Notice of Intent to } \\
\text { Issue dredge and fill } \\
\text { permit to Collier } \\
\text { Development } \\
\text { Corporation for a } \\
\text { development project } \\
\text { known as the Villages } \\
\text { of Sabal Bay. This was } \\
\text { issued after DER } \\
\text { approved the mitigation } \\
\text { and water quality } \\
\text { monitoring program } \\
\text { imposed upon CDC as } \\
\text { requisite permit } \\
\text { conditions. These }\end{array}$ & $\begin{array}{l}\text { The closest OFW } \\
\text { to the entire } \\
\text { project is the } \\
\text { Rookery Bay } \\
\text { Aquatic Preserve, } \\
\text { approximately } 2.5 \\
\text { miles south of the } \\
\text { proposed marina } \\
\text { and about a mile } \\
\text { south of the } \\
\text { intersection of the } \\
\text { Lely Canal and } \\
\text { the Intercoastal } \\
\text { Waterway south of } \\
\text { Dollar Bay. The } \\
\text { closest OFW to the } \\
\text { proposed marina } \\
\text { is located in }\end{array}$ & $\begin{array}{l}\text { Whether DER should grant } \\
\text { Collier Development } \\
\text { Corporation a dredge and fill } \\
\text { permit for a development } \\
\text { project known as the Villages } \\
\text { of Sabal Bay. }\end{array}$ & $\begin{array}{l}\text { "Habitat changes within the } \\
\text { development have been balanced } \\
\text { with mitigation and monitoring } \\
\text { requirements set forth as } \\
\text { conditions in the Notice of Intent } \\
\text { to Issue. This includes enhancing } \\
\text { approximately } 164 \text { acres of } \\
\text { wetlands, a donation of } 740 \text { acres } \\
\text { of wetlands, and a conservation } \\
\text { easement over another } 200 \text { acres." } \\
\text { ( } ₫ 78) \text {. }\end{array}$ & $\begin{array}{l}\text { "The flushing } \\
\text { characteristics of the } \\
\text { proposed marina are } \\
\text { important because water } \\
\text { quality in the marina and } \\
\text { its affects on surrounding } \\
\text { waters depend on how long } \\
\text { the water resides in the } \\
\text { marina." ( } 9 \text { 29). "The } \\
\text { application does not provide } \\
\text { reasonable assurance that } \\
\text { the marina will have } \\
\text { adequate flushing } \\
\text { characteristics so as to } \\
\text { prevent violations of water } \\
\text { quality standards in the } \\
\text { estuary." ( } ₫ \text { 38). However, it } \\
\text { was found that the OFWs in }\end{array}$ \\
\hline
\end{tabular}




\begin{tabular}{|c|c|c|c|c|c|}
\hline & $\begin{array}{l}\text { measures were placed } \\
\text { in the permit to offset } \\
\text { adverse effects within } \\
\text { the surrounding } \\
\text { estuary that may be } \\
\text { caused by the creation } \\
\text { of the marina basin and } \\
\text { the redesign of the Lely } \\
\text { Canal proposed in the } \\
\text { permit application. }\end{array}$ & $\begin{array}{l}\text { portions of Dollar } \\
\text { Bay. }\end{array}$ & & & $\begin{array}{l}\text { the designated portions of } \\
\text { Dollar Bay and Rookery Bay } \\
\text { will not be significantly } \\
\text { degraded by the project. ( } \Phi \\
\text { 92). }\end{array}$ \\
\hline $\begin{array}{l}\text { Lester Westerman } \\
\text { et al. v. Escambia } \\
\text { County Utilities } \\
\text { Authority and } \\
\text { DER, Case no. 89- } \\
\text { 0035 (1989) }\end{array}$ & $\begin{array}{l}\text { Permit to construct } \\
\text { pumping station, force } \\
\text { main, and land } \\
\text { application facility }\end{array}$ & $\begin{array}{l}\text { Big Lagoon - } \\
\text { Class III OFW }\end{array}$ & $\begin{array}{l}\text { Whether DER should grant } \\
\text { the revised application } \\
\text { Escambia County Utilities } \\
\text { Authority (ECUA) has made } \\
\text { for a permit to construct a } \\
\text { pumping station, force main, } \\
\text { and land application facility, } \\
\text { in order to dispose of effluent } \\
\text { from ECUA's Warrington } \\
\text { Sewage Treatment Plant on } \\
\text { a site in southwest Escambia } \\
\text { County near Big Lagoon. }\end{array}$ & No mitigation discussed & $\begin{array}{l}\text { It was recommended that } \\
\text { the permit should be denied. } \\
\text { However, the evidence was } \\
\text { clear that no direct } \\
\text { discharge to OFWs would } \\
\text { occur under any } \\
\text { circumstances. Effluent } \\
\text { already significantly diluted } \\
\text { before reaching the lagoon } \\
\text { would be further diluted } \\
\text { dramatically before a } \\
\text { portion mingled with the } \\
\text { OFWs. The evidence gave } \\
\text { reasonable assurance that } \\
\text { the project would not } \\
\text { significantly alter OFWs. }\end{array}$ \\
\hline $\begin{array}{l}\frac{\text { William Depkin v. }}{\text { DER, Case no. 89- }} \\
\underline{1309(1989)}\end{array}$ & $\begin{array}{l}\text { Permit to dredge a } 600 \\
\text { square foot area of bay } \\
\text { bottom in the cove } \\
\text { immediately waterward } \\
\text { of the seawall. The } \\
\text { proposed dredging } \\
\text { project would increase } \\
\text { the water depth by two } \\
\text { feet and "thereby } \\
\text { enable the Depkins to } \\
\text { dock their boat } \\
\text { alongside the seawall, a } \\
\text { location they consider } \\
\text { safer than the one they } \\
\text { presently use for this } \\
\text { purpose." ( } 13 \text { ) }\end{array}$ & $\begin{array}{l}\text { Key Largo, } \\
\text { Florida Bay - } \\
\text { Class III OFW. }\end{array}$ & $\begin{array}{l}\text { Whether Petitioner's } \\
\text { application for a permit to } \\
\text { dredge } 45 \text { cubic yards of } \\
\text { material in Florida Bay } \\
\text { immediately adjacent to the } \\
\text { seawall on his bayfront } \\
\text { property in Key Largo should } \\
\text { be granted. The project } \\
\text { which the "Depkins now } \\
\text { propose to undertake } \\
\text { involves the dredging of } \\
\text { primarily bedrock, not sand. } \\
\text { Revegetation typically does } \\
\text { not occur following such } \\
\text { dredging activity." ( } 9 \text { 9). }\end{array}$ & $\begin{array}{l}\text { "More likely than not, the } \\
\text { Depkins' proposed dredging } \\
\text { project, if permitted, will result in } \\
\text { the permanent loss of vegetation } \\
\text { and consequently will have a long- } \\
\text { term adverse effect on ambient } \\
\text { water quality, the conservation of } \\
\text { fish and other aquatic wildlife, and } \\
\text { marine productivity. Furthermore, } \\
\text { if the project was completed and } \\
\text { the Depkins were to begin docking } \\
\text { their boat alongside the seawall, } \\
\text { there would be an increase in } \\
\text { conflict turbidity attributable to } \\
\text { the movement of the boat in and } \\
\text { out of this area of shallow water. } \\
\text { No measures to mitigate these }\end{array}$ & $\begin{array}{l}\text { Petitioner failed to provide } \\
\text { reasonable assurances that } \\
\text { project will be in the public } \\
\text { interest or that water } \\
\text { quality standards will not } \\
\text { be violated. "If anything, it } \\
\text { appears that both water } \\
\text { quality and the public } \\
\text { interest would suffer, given } \\
\text { that there would likely be a } \\
\text { permanent loss of valuable } \\
\text { and productive vegetation } \\
\text { which would not be offset or } \\
\text { mitigated." ( } ₫ \text { 20). The area } \\
\text { is dominated by a "marine } \\
\text { macroalgae community" } \\
\text { within the meaning of r.17- }\end{array}$ \\
\hline
\end{tabular}




\begin{tabular}{|c|c|c|c|c|c|}
\hline & & & & $\begin{array}{l}\text { adverse consequences have been } \\
\text { proposed or suggested.” ( } 9 \text { 9). No } \\
\text { other mitigation was proposed } \\
\text { except installing turbidity curtains } \\
\text { during construction. }\end{array}$ & $\begin{array}{l}2.410(1)(\mathrm{a}) \text {, Fla. Admin. } \\
\text { Code, and the project should } \\
\text { therefore not be permitted. } \\
\text { ( } ₫ 19) \text {. Granting the permit } \\
\text { would set a precedent that } \\
\text { would have a cumulative } \\
\text { impact and "adversely } \\
\text { impact areas well beyond } \\
\text { the boundaries of the } \\
\text { proposed dredging site." ( } \\
\text { 20). }\end{array}$ \\
\hline $\begin{array}{l}\text { Florida Audubon } \\
\text { Society, et al. v. } \\
\text { William Cullen } \\
\text { and DER, Case } \\
\text { nos. 89-3779, 89- } \\
3780,89-3781,89- \\
\underline{3782,89-4060,89-} \\
\underline{4388(1989)}\end{array}$ & $\begin{array}{l}\text { Dredge and fill permit } \\
\text { for } 42 \text {-slip commercial } \\
\text { marina that would } \\
\text { require the excavation } \\
\text { of uplands and the } \\
\text { dredging of an } \\
\text { existing basin created } \\
\text { by the excavation of } \\
\text { materials used for } \\
\text { road construction. The } \\
\text { Applicant seeks to } \\
\text { attract boats in the } \\
\text { range of } 30 \text { - } 50 \text { feet in } \\
\text { length. }\end{array}$ & $\begin{array}{l}\text { The project site is } \\
\text { in Key Largo, } \\
\text { Florida and } \\
\text { located in } \\
\text { Buttonwood } \\
\text { Sound, within } \\
\text { Florida Bay, a } \\
\text { Class III OFW. }\end{array}$ & $\begin{array}{l}\text { Whether the DER should } \\
\text { grant a dredge and fill } \\
\text { permit to construct a } \\
\text { commercial marina that } \\
\text { would require the } \\
\text { excavation of } 30,170 \text { square } \\
\text { feet of uplands and the } \\
\text { dredging of approximately } \\
18,460 \text { dredged square feet } \\
\text { of an existing basin. }\end{array}$ & $\begin{array}{l}\text { Applicant proposed to install } \\
\text { turbidity curtains during the } \\
\text { construction phase. }\end{array}$ & $\begin{array}{l}\text { It was not established that } \\
\text { water quality standards } \\
\text { would be met and that the } \\
\text { waters within the } \\
\text { Buttonwood Sound would } \\
\text { not be degraded. Applicant } \\
\text { also failed to show that the } \\
\text { project is clearly in the } \\
\text { public interest. The } \\
\text { Applicant even failed to } \\
\text { meet the burden of the } \\
\text { lesser standard, that the } \\
\text { project is not contrary to } \\
\text { the public interest. Permit } \\
\text { denied. }\end{array}$ \\
\hline $\begin{array}{l}\text { Charms Clarke } \\
\text { and Judith Clarke } \\
\text { (89-6051) and } \\
\text { Claudette Traurig } \\
\text { (89-6135) v. Floyd } \\
\text { Melton, Alice } \\
\text { Melton and DER } \\
\text { (1990) }\end{array}$ & $\begin{array}{l}\text { An "after-the-fact" } \\
\text { dredge and fill permit } \\
\text { for an already } \\
\text { constructed } 48 \text { ' x } 20 \\
\text { portion of a finger } \\
\text { dock. There are } \\
\text { seagrasses under the } \\
\text { entire length of the } \\
\text { dock. }\end{array}$ & $\begin{array}{l}\text { Key Largo, } \\
\text { Florida Bay - } \\
\text { Class III OFW }\end{array}$ & $\begin{array}{l}\text { Whether the applicants- } \\
\text { respondents Floyd and Alice } \\
\text { Melton have provided } \\
\text { reasonable assurances that } \\
\text { their proposed dock meets } \\
\text { the requirements for } \\
\text { issuance of an "after-the-fact" } \\
\text { dredge and fill permit. }\end{array}$ & $\begin{array}{l}\text { "The Meltons and DER entered } \\
\text { into several stipulations which } \\
\text { will promote the absence of } \\
\text { impact to the seagrass } \\
\text { community." ( } \mathbb{1} 15) \text {. "It is } \\
\text { strongly recommended that DER } \\
\text { also condition the Melton dock } \\
\text { permit with the requirement that } \\
\text { the dangers at nighttime be } \\
\text { mitigated by some form of } \\
\text { reflective paint or lighting for } \\
\text { that section of the dock which } \\
\text { extends beyond the distance of } \\
\text { the other docks in the immediate } \\
\text { vicinity." }(\Phi 22) \text {. }\end{array}$ & $\begin{array}{l}\text { The permit is granted, } \\
\text { conditioned upon the } \\
\text { stipulations and mitigation } \\
\text { requirements. "Reasonable } \\
\text { assurances have been given } \\
\text { that the project will not } \\
\text { adversely affect any water } \\
\text { quality standards, and that } \\
\text { it will affect neither the } \\
\text { public interest in navigation } \\
\text { nor public recreation in the } \\
\text { vicinity." ( } \$ 1 \text { 19). Rule 17- } \\
\text { 312.420, Fla. Admin. Code } \\
\text { creates a presumption that } \\
\text { docks that extend out to the } \\
5 \text { ' depth contour, where } \\
\text { seagrasses are otherwise }\end{array}$ \\
\hline
\end{tabular}




\begin{tabular}{|c|c|c|c|c|c|}
\hline & & & & & $\begin{array}{l}\text { present, are clearly in the } \\
\text { public interest." (ף 20). } \\
\text { Project "is clearly in the } \\
\text { public interest by } \\
\text { preventing ongoing adverse } \\
\text { impacts of the existing dock, } \\
\text { allowing the recolonization } \\
\text { of habitat in those disturbed } \\
\text { areas, and by extending the } \\
\text { dock to prevent the } \\
\text { destruction of the bay } \\
\text { bottom." ( } ₫ 14) \text {. }\end{array}$ \\
\hline $\begin{array}{l}\text { CW Pardee, Jr. v. } \\
\text { DER, Case nos. 90- } \\
\underline{\text { 5734 and 90-0911 }} \\
\underline{(1991)}\end{array}$ & $\begin{array}{l}\text { Permit to dredge a } \\
\text { man-made canal and } \\
\text { to construct two } \\
\text { boathouses with six } \\
\text { boat slips. }\end{array}$ & $\begin{array}{l}\text { Property located } \\
\text { in Marion County, } \\
\text { Florida. Petitioner } \\
\text { has legal access to } \\
\text { a man-made canal } \\
\text { that intersects the } \\
\text { Oklawaha River, } \\
\text { an OFW. While } \\
\text { the canal itself is } \\
\text { not an OFW, the } \\
\text { Oklawaha River's } \\
\text { ambient water } \\
\text { quality would be } \\
\text { at risk from the } \\
\text { dredging activities } \\
\text { contemplated by } \\
\text { this project. ( } \mathbf{9} 40) \text {. }\end{array}$ & $\begin{array}{l}\text { Whether Petitioner's request } \\
\text { for a permit to dredge in a } \\
\text { man-made canal and to } \\
\text { construct two boat houses } \\
\text { and six boat slips should be } \\
\text { granted. DER initially } \\
\text { issued a notice to deny the } \\
\text { permit. }\end{array}$ & $\begin{array}{l}\text { To mitigate the effects of this } \\
\text { project, Petitioner has offered to } \\
\text { place a recycling waterfall in or } \\
\text { near the proposed boat basin to } \\
\text { increase oxygenation. Petitioner } \\
\text { also proposes to landscape the } \\
\text { slopes of the basin with boulders } \\
\text { and natural vegetation and place } \\
\text { "no wake" signs along the basin. } \\
\text { Moreover, Petitioner proposes to } \\
\text { use a turbidity curtain to protect } \\
\text { against violations of turbidity } \\
\text { standards. }\end{array}$ & $\begin{array}{l}\text { "Necessary reasonable } \\
\text { assurances have not been } \\
\text { given that the ambient } \\
\text { water quality in the } \\
\text { Oklawaha River will not be } \\
\text { degraded by this project." ( } ₫ \\
\text { 44). Turbidity and water } \\
\text { quality violations are } \\
\text { probable, given the river's } \\
\text { fast current which precludes } \\
\text { the efficient use of turbidity } \\
\text { screens or curtains. ( } 91 \text { ). } \\
\text { "Petitioner has failed to give } \\
\text { reasonable assurances that } \\
\text { the project is not contrary to } \\
\text { the public interest. In this } \\
\text { balancing test, the proof } \\
\text { shows that the project } \\
\text { would adversely affect fish } \\
\text { and wildlife and their } \\
\text { habitat. Further it has been } \\
\text { shown that the project is } \\
\text { contrary to public health, } \\
\text { safety and welfare and to } \\
\text { property of others." ( } 45 \text { ). } \\
\text { The artificial waterfall is } \\
\text { not an acceptable solution } \\
\text { as it only would address } \\
\text { dissolved oxygen water } \\
\text { quality and not other } \\
\text { regulatory parameters. }\end{array}$ \\
\hline
\end{tabular}




\begin{tabular}{|c|c|c|c|c|c|}
\hline $\begin{array}{l}\text { Kathryn } \\
\text { Haughney v. } \\
\text { DER, Case no. 90- } \\
\underline{7215(1991)}\end{array}$ & $\begin{array}{l}\text { Dredge and fill permit } \\
\text { for dock and seawall } \\
\text { construction. }\end{array}$ & $\begin{array}{l}\text { The Halifax River, } \\
\text { a Class III water. } \\
\text { The Haughney } \\
\text { property is located } \\
\text { and the dock and } \\
\text { seawall are } \\
\text { proposed within } \\
\text { the Tomoka } \\
\text { Marsh Aquatic } \\
\text { Preserve, an } \\
\text { OFW. }\end{array}$ & $\begin{array}{l}\text { Whether Petitioner is } \\
\text { entitled to a dredge and fill } \\
\text { permit to construct a dock } \\
\text { and seawall. }\end{array}$ & $\begin{array}{l}\text { The area to be filled provides } \\
\text { lush wetland vegetation that } \\
\text { provides valuable habitat for fish } \\
\text { and wildlife. "There was no } \\
\text { mitigation offered by Petitioner } \\
\text { to make up for the loss of habitat } \\
\text { to be occasioned by the proposed } \\
\text { construction." ( }(6) \text {. }\end{array}$ & $\begin{array}{l}\text { Because the proposed } \\
\text { seawall is to be constructed } \\
\text { within an OFW, Petitioner } \\
\text { bears the burden to go } \\
\text { forward and prove that the } \\
\text { project is clearly in the } \\
\text { public interest. "As the } \\
\text { permit application now } \\
\text { stands, it must be denied } \\
\text { because it has the potential } \\
\text { to adversely affect the } \\
\text { property of others and the } \\
\text { conservation of fish and } \\
\text { wildlife, and because it may } \\
\text { cause harmful erosion." ( } \ \\
\text { 17). "Construction of } \\
\text { seawalls, especially those } \\
\text { that extend out from the } \\
\text { existing shoreline, typically } \\
\text { causes erosion on adjacent } \\
\text { shorelines, and additional } \\
\text { seawalls exaggerate wave } \\
\text { energy and can have a } \\
\text { cumulative erosive effect." } \\
\text { ( } \text { 8). }\end{array}$ \\
\hline $\begin{array}{l}\text { John Armenia v. } \\
\text { Board of Trustees } \\
\text { of the Internal } \\
\text { Improvement Trust } \\
\text { Fund, et al., Case } \\
\text { no. } 91-3249 \text { (1991); } \\
\text { Case revisited in } \\
\underline{91-36770 .}\end{array}$ & $\begin{array}{l}\text { Dredge and fill permit } \\
\text { "to construct a } 490 \text {-foot } \\
\text { elevated driveway or } \\
\text { timber bridge across } \\
\text { Clam Bayou from the } \\
\text { Sanibel-Captiva Island } \\
\text { Road to Silver Key, on } \\
\text { and in the vicinity of } \\
\text { Sanibel Island to } \\
\text { allegedly provide } \\
\text { reasonable access to the } \\
\text { property upon which he } \\
\text { intends to construct } \\
\text { residences. }\end{array}$ & $\begin{array}{l}\text { Pine Island } \\
\text { Sounds Aquatic } \\
\text { Preserve, an } \\
\text { OFW. }\end{array}$ & $\begin{array}{l}\text { Petitioner argues that a } \\
\text { statement by DER contained } \\
\text { in a letter "was a rule, not } \\
\text { duly promulgated, and thus } \\
\text { that it constituted an invalid } \\
\text { exercise of delegated } \\
\text { legislative authority." The } \\
\text { agency statement in } \\
\text { question, in effect, made a } \\
\text { determination that the } \\
\text { Petitioner's proposed project } \\
\text { was within the boundaries of } \\
\text { the Pine Island Sound } \\
\text { Aquatic Preserve and thus } \\
\text { imposed a more restrictive } \\
\text { body of rules on the } \\
\text { Petitioner. }\end{array}$ & N/A & $\begin{array}{l}\text { "It was not proven in this } \\
\text { proceeding that the agency } \\
\text { statement evidences any } \\
\text { intent to amend or change } \\
\text { the legal description of the } \\
\text { preserve ... Rather, it } \\
\text { represents ... an } \\
\text { interpretation concerning } \\
\text { whether the Petitioner's } \\
\text { property is located within } \\
\text { the legal boundaries." ( } \mathbf{9} \text { ). } \\
\text { Final Order: } \\
\text { Although it was the intent } \\
\text { of the Board of Trustees to } \\
\text { include Clam Bayou in Pine } \\
\text { Island Sound Aquatic } \\
\text { Preserve, the ambiguity of }\end{array}$ \\
\hline
\end{tabular}




\begin{tabular}{|c|c|c|c|c|c|}
\hline & & & & & $\begin{array}{l}\text { the legal description and the } \\
\text { exclusion of Clam Bayou } \\
\text { from DNR's maps do not } \\
\text { effectuate this position. The } \\
\text { Petitioner's challenge is } \\
\text { dismissed. The DER } \\
\text { statement is merely an } \\
\text { interpretation of the scope } \\
\text { of the existing rule, not a } \\
\text { change to the existing rule. }\end{array}$ \\
\hline $\begin{array}{l}\text { Sarah Berger v. } \\
\text { William Kline, } \\
\text { DER, and Citrus } \\
\text { County, Case no. } \\
\text { 93-0264 (1993) }\end{array}$ & $\begin{array}{l}\text { Permit to construct a } \\
\text { private boat dock with } \\
\text { a roof, designed to } \\
\text { cover a boat. }\end{array}$ & $\begin{array}{l}\text { Withlacoochee } \\
\text { River - Class III } \\
\text { OFW. }\end{array}$ & $\begin{array}{l}\text { Whether Applicant for the } \\
\text { dredge and fill permit has } \\
\text { provided reasonable } \\
\text { assurances that the project } \\
\text { will comport with state water } \\
\text { quality and public interest } \\
\text { standards; whether Citrus } \\
\text { County has standing to } \\
\text { challenge the project; and } \\
\text { whether the Department is } \\
\text { required or authorized to } \\
\text { enforce the provisions of the } \\
\text { Citrus County } \\
\text { Comprehensive Plan. }\end{array}$ & $\begin{array}{l}\text { Conditions in the Notice of Intent } \\
\text { to Issue required Kline to clear the } \\
\text { existing bank of nuisance plants } \\
\text { and to plant and maintain } \\
\text { identified native plant species and } \\
\text { to grant to the FDEP a perpetual } \\
\text { conservation easement along his } \\
\text { shoreline. The conservation } \\
\text { easement was required in order to } \\
\text { help protect the replanted } \\
\text { shoreline and prevent further } \\
\text { shoreline hardening through } \\
\text { construction of a seawall or other } \\
\text { structures in the future. Moreover, } \\
\text { eleven specific permit conditions } \\
\text { pertaining solely to protection of } \\
\text { manatees were required. }\end{array}$ & $\begin{array}{l}\text { The mitigation } \\
\text { requirements are significant } \\
\text { conditions that are "clearly } \\
\text { in the public interest." No } \\
\text { adverse cumulative impacts } \\
\text { are expected on water } \\
\text { quality or the public } \\
\text { interest because "evidence } \\
\text { does not establish that other } \\
\text { similar structures are } \\
\text { contemplated or the subject } \\
\text { matter of other permit } \\
\text { applications." ( } ₫ \text { 39). The } \\
\text { application is granted under } \\
\text { the conditions found and } \\
\text { contained in the intent to } \\
\text { issue. }\end{array}$ \\
\hline $\begin{array}{l}\text { Helen Sutton v. } \\
\text { Tana Hubbard and } \\
\text { DEP, Case nos. 93- } \\
\text { 1499 and 93-6507 } \\
\underline{(1994)}\end{array}$ & $\begin{array}{l}\text { Dredge and fill permit } \\
\text { and after-the-fact } \\
\text { consent of use for } \\
\text { existing retaining wall } \\
\text { and dock. }\end{array}$ & $\begin{array}{l}\text { The project is } \\
\text { located in a lagoon } \\
\text { off Kings Bay, in } \\
\text { the Crystal River } \\
\text { in Citrus County, } \\
\text { Florida. It is in a } \\
\text { man-altered Class } \\
\text { III waterbody and } \\
\text { OFW. }\end{array}$ & $\begin{array}{l}\text { Whether DEP should issue a } \\
\text { permit for an existing } \\
\text { retaining wall and dock } \\
\text { located at the residence of } \\
\text { Respondent Hubbard and } \\
\text { whether the Department } \\
\text { should issue an after-the- } \\
\text { fact consent of use for the } \\
\text { dock. }\end{array}$ & $\begin{array}{l}\text { The permit required Hubbard to } \\
\text { create } 346 \text { square feet of wetlands } \\
\text { as mitigation and to dedicate all } \\
\text { remaining wetlands on the site to } \\
\text { the FDEP as a conservation } \\
\text { easement. }\end{array}$ & $\begin{array}{l}\text { "Any impacts that have } \\
\text { occurred from the dock are } \\
\text { minimal and are } \\
\text { compensated for in the } \\
\text { mitigation plan. The project } \\
\text { creates a permanent } \\
\text { conservation easement over } \\
400 \text { feet of shoreline and } \\
\text { wetlands, thereby } \\
\text { preserving fish and wildlife } \\
\text { habitat. The retaining wall } \\
\text { provides some water quality } \\
\text { benefit." ( } 9 \text { 64). "The as- } \\
\text { built dock, existing docks, } \\
\text { and reasonably anticipated }\end{array}$ \\
\hline
\end{tabular}




\begin{tabular}{|c|c|c|c|c|c|}
\hline & & & & & $\begin{array}{l}\text { future docks do not create } \\
\text { any adverse cumulative } \\
\text { impacts." ( } ₫ \text { 65). The } \\
\text { Consent Order is approved } \\
\text { and the after-the-fact } \\
\text { application for consent of } \\
\text { use for the sovereign } \\
\text { submerged lands underlying } \\
\text { the dock is granted. }\end{array}$ \\
\hline $\begin{array}{l}\text { Clifford Hunter v. } \\
\text { DEP, Case no. 93- } \\
\underline{5924(1994)}\end{array}$ & $\begin{array}{l}\text { After his home was } \\
\text { destroyed by storm in } \\
\text { 1993, Mr. Hunter } \\
\text { applied for a dredge } \\
\text { and fill permit for } \\
\text { construction of a } \\
\text { bulkhead, dock, and to } \\
\text { rebuild his pile- } \\
\text { supported house. } \\
\text { "Approval of Mr. } \\
\text { Hunter's proposed } \\
\text { project would allow } \\
\text { the placing of fill in an } \\
\text { intertidal area and the } \\
\text { elimination of the } \\
\text { portion of the } \\
\text { intertidal area filled." } \\
\text { ( } 13 \text {. }\end{array}$ & $\begin{array}{l}\text { A canal adjacent } \\
\text { to Mr. Hunter's } \\
\text { northern property } \\
\text { boundary connects } \\
\text { with the waters of } \\
\text { the Gulf of Mexico } \\
\text { surrounding Dekle } \\
\text { Beach. These } \\
\text { waters, except for } \\
\text { an area extending } \\
500 \text { feet outward } \\
\text { from the town } \\
\text { limits of Dekle } \\
\text { Beach, is within } \\
\text { the Big Bend } \\
\text { Seagrasses } \\
\text { Aquatic Preserve, } \\
\text { an OFW. } \\
\text { Therefore, the } \\
\text { project site is } \\
\text { adjacent to an } \\
\text { OFW. }\end{array}$ & $\begin{array}{l}\text { Whether Petitioner should be } \\
\text { permitted to rebuild a pile- } \\
\text { supported house, to construct } \\
\text { a bulkhead, to fill } 1750 \\
\text { square feet of salt marsh, } \\
\text { and to construct a dock. DEP } \\
\text { originally issued a Notice of } \\
\text { Permit Denial denying the } \\
\text { requested permit. }\end{array}$ & No mitigation discussed. & 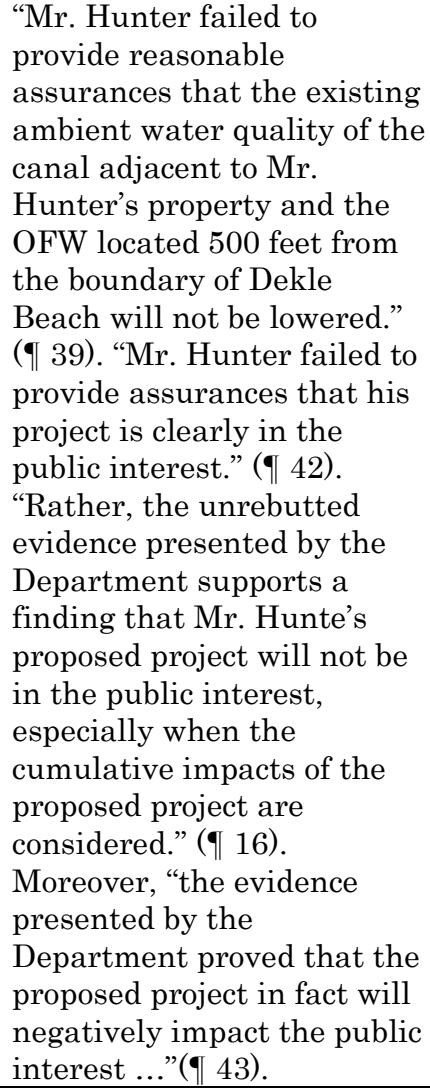 \\
\hline
\end{tabular}




\begin{tabular}{|c|c|c|c|c|c|}
\hline $\begin{array}{l}\text { Alden Pond, Inc. } \\
\underline{\text { v. DEP, Case no. }} \\
\underline{93-6982(1994)}\end{array}$ & $\begin{array}{l}\text { Petitioner proposes to } \\
\text { construct a canal with } \\
\text { littoral zones on either } \\
\text { side, a hydrological } \\
\text { channel to enable a } \\
\text { proper flow of water } \\
\text { through the canal, and } \\
\text { a barrier at the north } \\
\text { terminus of the canal to } \\
\text { prevent manatees and } \\
\text { boats from entering the } \\
\text { canal from the north. ( } \\
\text { 33). An access channel } \\
\text { is also proposed from } \\
\text { the south terminus to } \\
\text { the Intercoastal } \\
\text { Waterway to enable } \\
\text { boats access to the } \\
\text { canal. A total of } 62 \\
\text { docks are proposed. }\end{array}$ & $\begin{array}{l}\text { Much of the } \\
\text { property abuts a } \\
\text { section of the } \\
\text { Indian River. The } \\
\text { Indian River at } \\
\text { the project site is } \\
\text { within the Indian } \\
\text { River Aquatic } \\
\text { Preserve, a Class } \\
\text { II OFW. }\end{array}$ & $\begin{array}{l}\text { Whether Petitioner is } \\
\text { entitled to a wetland } \\
\text { resource permit to construct } \\
\text { an artificial waterway to be } \\
\text { connected to the Indian River } \\
\text { and, if so, the conditions that } \\
\text { should be attached to the } \\
\text { permit. Whether Respondent } \\
\text { is estopped to deny the } \\
\text { issuance of the permit. } \\
\text { Whether Petitioner is } \\
\text { entitled to a default variance } \\
\text { pursuant to } § 120.60(2) \text {, Fla. } \\
\text { Stat., to dredge and fill in } \\
\text { Class II waters that have } \\
\text { been conditionally approved } \\
\text { for shellfish harvesting. }\end{array}$ & 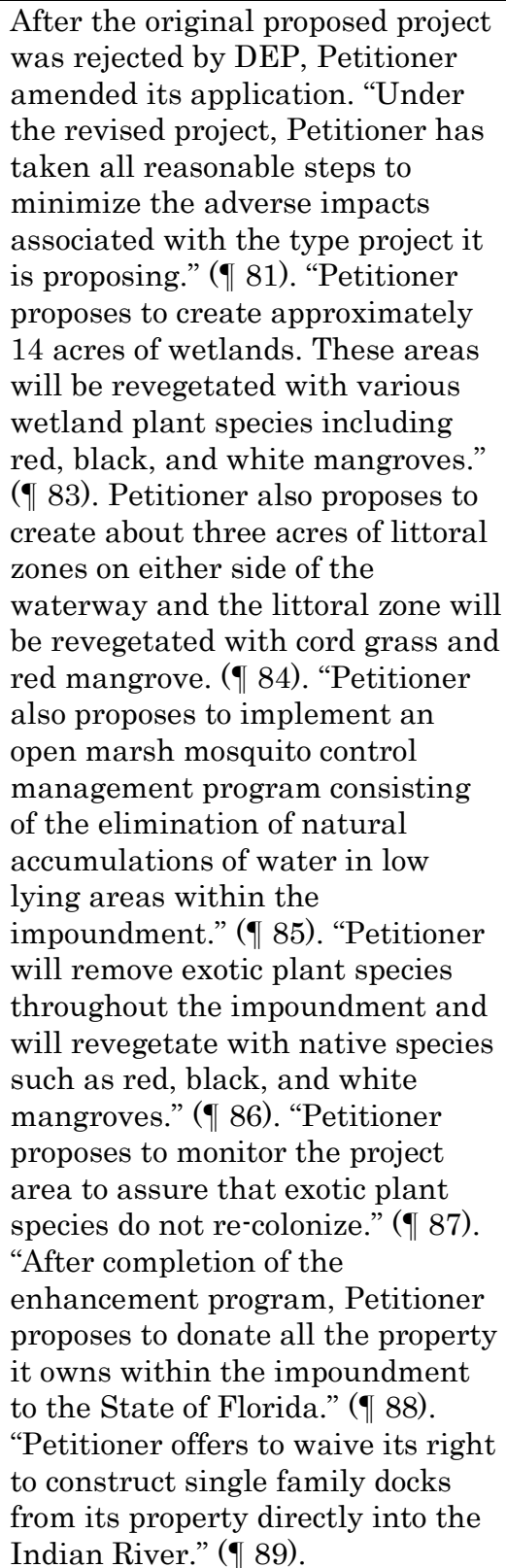 & $\begin{array}{l}\text { "Although Respondent } \\
\text { established that boat traffic } \\
\text { on the Indian River has } \\
\text { increased, this project is } \\
\text { unique in scope and design, } \\
\text { and it is concluded that } \\
\text { Petitioner has given } \\
\text { reasonable assurances that } \\
\text { no negative cumulative } \\
\text { impacts will be associated } \\
\text { with the project." ( } 177 \text { ). } \\
\text { However, Petitioner's } \\
\text { request for variance is } \\
\text { denied. "Without the } \\
\text { variance to construct the } \\
\text { hydrological channel, the } \\
\text { modified application for this } \\
\text { project should be denied." ( } \\
\text { 114). "The modified } \\
\text { application should be denied } \\
\text { even if the variance to } \\
\text { construct the hydrological } \\
\text { channel is granted. Specific } \\
\text { findings of fact have been } \\
\text { made as to the adverse } \\
\text { impacts of this project and } \\
\text { as to the mitigation plan } \\
\text { proposed to offset those } \\
\text { adverse impacts." ( } 115 \text { ). }\end{array}$ \\
\hline
\end{tabular}




\begin{tabular}{|c|c|c|c|c|c|}
\hline $\begin{array}{l}\text { DEP v. Ben } \\
\text { Leasure, Case no. } \\
\underline{\text { p4-3688 (2005) }}\end{array}$ & $\begin{array}{l}\text { Respondent allegedly } \\
\text { filled wetlands on his } \\
\text { property without a } \\
\text { permit. }\end{array}$ & $\begin{array}{l}\text { The western } \\
\text { boundary of } \\
\text { Leasure's parcel } \\
\text { is approximately } \\
500 \text { feet east of } \\
\text { the } \\
\text { Withlacoochee } \\
\text { River, a Class III } \\
\text { OFW. }\end{array}$ & $\begin{array}{l}\text { Whether Respondent } \\
\text { Leasure should have a } \\
\$ 3,000.00 \text { administrative } \\
\text { penalty imposed, take } \\
\text { specific corrective action, } \\
\text { and pay investigative costs } \\
\text { for allegedly illegally filling } \\
0.17 \text { acres of wetlands } \\
\text { contiguous with the } \\
\text { Withlacoochee River. }\end{array}$ & $\begin{array}{l}\text { "While Respondent may have } \\
\text { been well-intentioned in trying to } \\
\text { prevent flooding on the backside } \\
\text { of his property, there are no } \\
\text { circumstances present here } \\
\text { which would allow a mitigation } \\
\text { of the statutory penalty." ( } ₫ 33) \text {. }\end{array}$ & $\begin{array}{l}\text { "Here, there were no good } \\
\text { faith efforts to comply } \\
\text { prior to and after the } \\
\text { discovery of the violation } \\
\text { by the department. Had } \\
\text { Respondent agreed to } \\
\text { remove the fill after the } \\
\text { first warning letter was } \\
\text { sent, or even after the first } \\
\text { inspection, it is likely that } \\
\text { an enforcement action } \\
\text { would not have been } \\
\text { initiated." ( } ₫ 32 \text { ). Section } \\
403.121(3) \text {, Fla. Stat., sets } \\
\text { forth the administrative } \\
\text { penalties that must be } \\
\text { imposed (absent } \\
\text { mitigating circumstances) } \\
\text { for specified violations. } \\
\text { Paragraph (3)(c) provides } \\
\text { that "the department shall } \\
\text { assess a penalty of } \\
\$ 1,000 \text { for unpermitted or } \\
\text { unauthorized dredging and } \\
\text { filling ... plus } \$ 2,000 \text { if the } \\
\text { dredging and filling occurs } \\
\text { in an ... [OFW]." } \\
\text { Therefore, because the } \\
\text { filling here occurred in an } \\
\text { area connected to an OFW, } \\
\text { absent mitigating } \\
\text { circumstances, an } \\
\text { administrative penalty of } \\
\$ 3000.00 \text { must be } \\
\text { imposed." ( } \text { ( } 30 \text { ). } \\
\text { Moreover, the Department } \\
\text { has suggested specific } \\
\text { corrective action that } \\
\text { should be taken by } \\
\text { Respondent. }\end{array}$ \\
\hline
\end{tabular}

